Gas Content of Gladys McCall Reservoir Brine

\author{
A Topical Report
}

\author{
Prepared by \\ C.G. Hayden \\ P.L. Randolph \\ Institute of Gas Technology \\ 3424 South State Street \\ Chicago, Illinois 60616
}

Submitted to

Eaton Operating Company

1980 Post Oak Boulevard, Suite 2000

Houston, Texas 77056

Under Sub-contract No. EOC 85-4

(EOC/IGT)

Under Prime Contract No. DE-AC07-85ID12578

(DOE/EOC)

IGT Project No. 65071

May 1987 


\section{DISCLAIMER}

This report was prepared as an account of work sponsored by an agency of the United States Government. Neither the United States Government nor any agency Thereof, nor any of their employees, makes any warranty, express or implied, or assumes any legal liability or responsibility for the accuracy, completeness, or usefulness of any information, apparatus, product, or process disclosed, or represents that its use would not infringe privately owned rights. Reference herein to any specific commercial product, process, or service by trade name, trademark, manufacturer, or otherwise does not necessarily constitute or imply its endorsement, recommendation, or favoring by the United States Government or any agency thereof. The views and opinions of authors expressed herein do not necessarily state or reflect those of the United States Government or any agency thereof. 


\section{DISCLAIMER}

Portions of this document may be illegible in electronic image products. Images are produced from the best available original document. 


\section{Executive Summary}

On octoter 6.1983 , after the first full day of production from sand $\$ 6$ in the Gladys Mocall well, samples of separatar gas and separatar brine were collected for latoratary P-V-T pressure, volume temperature) studies Recombination of amounts of these samples tiged upon measured rotes at the time of sample collection, and at reservoir temperature (290 Deg. F.). revealed a bubtile point pressure of 9200 psia. This is substantially telow the reported reservoir pressure of 12,783 psis. The gas ontent of the recombined fluids was 30.19 SLF of dry gas/STE of brine in contrast. iatoratory studies indicate that $3584 \mathrm{SCF}$ of pure methane would disonive in esch STB of $95,000 \mathrm{mg} / 1$ sodium choride trine. These results indicate that the reservoir brine was not saturated with natural gas

Ey early April, 1967, production of roughly 25 million barrels of trine had reduced calculated flowing bottamhole pressure to about b6ou psis at a brine rate of $22,000 \mathrm{STB} / 0$. If the skin factor $(s)$ were $\sigma s$ high as 20 , nowing pressure drop across the skin wauld still be only atout 500 psi Thus, same partion of the reseryair volume was believed to hise teen drown down to below the butitle paint deduced from the laboratary recombination of separator samples.

When the pressure in a geopressured geothermal reservoir is reduced to below the tubbie point pressure for solution gos gos is exsolved from the brine flowing through the pores in the reservair rock. This exeolved gos is tropped in the reservoir until the froctional gas soturation af pore wolume becomes large enough for gos flow to commence through a cantinuous gas-filled channel. At the same time the gas/arine ratio becomes smaller and the chemistry of the remaining solution gas changes for the trine from which gas is exsolved.

A careful search was made for the changes in gas/trine ratio or solution gas chemistry that would accompany pressure dropping telow the bubble point pressure. Changes of atout the same magnitude as the scatter in the data appear to have occurred in mid-1985 when colculated flowing bot tombale pressure was in the range of 9400 to 9700 psi. 
After the amount of brine flowing through rock near to the wellture his exsolved enough gas for onset of gas motility through a continuous gos-filled charnel, another test for whether the reservor is betaw its bubble point becomes possible. The "buttie test" consists of suddeniy increasing flow rate so that bottomble pressure drops. Gas expansion then results in a small fortion of the free gos from near the welture teing produced in a short period of time. The resulting "bubale" of gos has o higher notural gos liquids content than gas produced before and af ter the trensient.

"Bubble tests" were performed in Fetruary 1966 and April 1987. Neither test liberated enough additional gos ta provide a detectatile change in produced gas/brine rotio. However, atemed smol troments in Ethane/Methane and Fropane/Methane ratios indiogte that some free gas was produced fram the near weilbore region. These results suggest thet the bubtle point pressure must have teen in the vicinity of the calculated 9500 psi flawing bottamhale pressure during the second half of 1965

We conclude that:

- Sand *6 in the Giadys Mocoll well was NOT soturated with natura? gas at the reparted initial reservair pressure of 12,673 psio.

- Flowing bottomhole pressure became less than the tutitile paint pressure during 1965.

- Eutbie point pressure was in the range of 9200 to 10000 pel.

It is noted that a large increase in Birium content, as well as ameller changes in cancentratians of ather disealued species, were oberted at sbout the same time that near wellowe nowing pressure fell below the butble point pressure. If these changes stgnalled arrival of brine from a diferent reservoir compartment, that brine was alen undereaturated with notural gos at the initial reservour pressure. 


\section{Gas Content of Gladys McCall Reservoir Brine}

Table of Contents

\subsection{GAS PRODUCTION, MEASUREMENT, AND ANALYSES pg. 2}

1.1 Gas Analyses

1.2 Gas Rate Measurement

pg. 2

1.2.1 Orifice Metering

pg. 5

1.2.2 Gas in Brine

1.3 Gas Production and Gas/Brine Ratios

pg. 6

pg. 10

1.4 Total Gas Measurement

pg. 12

pg. 15

\subsection{GAS CONTENT OF RESERVOIR BRINE}

$2.1 \mathrm{P}-\mathrm{V}$-T Studies

2.2 Changes in the Produced Gas to Brine Ratio

pg. 17

pg. 18

pg. 19

2.3 Changes in the Produced Gas Composition

pg. 20

2.4 The IGT Bubble Test

pg. 23

2.4.1 Physical Phenomena That Cause the Bubble

pg. 26

2.4.2 The Febuary 11, 1986 Bubble Test

pg. 27

2.4.3 The April 14, 1987 Bubble Test

pg. 30

2.4.4 Discussion of Bubble Test Results

pg. 32

3.0 CONCLUSIONS FOR THE GLADYS MCCALL WELL

pg. 34

4.0 OTHER DESIGN WELLS AND RECOMMENDATIONS

pg. 35

\subsection{APPENDICES}
A Weatherly Laboratories, Inc. Reservoir Fluid Analysis
Gladys McCall Well No. 1 , Sand 8
B Gas Analyses by Sample Location
C Compilation of "Total Gas" Analyses 


\title{
Gas Content of Gladys McCall Reservoir Brine
}

\author{
C. Hayden \& P. Randolah \\ institute of Gas Technology \\ lay 29.1987
}

This report addresses two aspects of gas production from sand *8 The first is the rate and composition of the froduced ges. The second is whether or not the aquifer is saturated with natural gis

These topics were previously addresed for this sand by ather authors after only a few million barrels of brine had been produced and when drawdown of the reservoir was lese than 1000 psi. The basic question for this report is whether data from production of roughly 25 million barrels of brine and drawdown of about 4000 fes make aporopriate revisions to prior conclusions.

After atout 24 hours of production at 13,400 BPD separator gas and brine samples were collected at a pressure of 500 fsi for laboratory P-V-T (aressure volume, temperature) anglyses on october 8. 1983. The latoratory analysis report is prowided herewith as appendix $A$. Note that recombination of the sampled fluid phases in a ratio defined by flow rate data resulted in a bubble point pressure of 9200 psia wherees the initial reservoir preseure had ben reported to be 12,783 psia.

This latoratory result from sampling at the beginning of testing of sand * was the basis for Mr. Larry currett reporting in Lanuary 10.1984 that "-- , in fact this reservoir is slightly undersaturated with respert to natural gas. If you extrapolate the curve out to the reservour pressure. which is slightly lese than 13000 pounds. it shows that its 610 about 80\% Saturated" MINUTES FROM - DOEE/INOUSTRY GEOFRESSURE GEOTHERMAL RESOURCE DEVELDPMENT PROGRAM WORKING GROUP MEETINGS. CK GeoEnergy Corporation. DOE/H\&N/CKG/3-84). In his paper in the Proceedings of the Sixth U.S. Gulf Coast Geopressured-Geothermal Energy Conference, Austin TX, February 4-6, 1985, Mr. Don Clark similarily stated "The reservoir fluid appears to be undersoturated with notural hydrocarton gases of about 31 . cubie feet of dry gas per standard barrel of brine". 
Revisiting the question of gas content of brine is particularily important because (1) coning of iree gas into the wellbore with continuing drawdown would dramatically improve the econamics of production and (2) the early flow testing of the well involved seriaus problems in atitaming and interpreting gas production rate data. Indeed, calculated gas rates at the times of sampling are the only reported rates that we have been able to find for the 21 day test of Sand 8 during Octuber and November of 1963 . This raises the question as to whether the recombination bubtile foint of 9200 psia is in error due to error in the rate data that was the tasis for selecting the quantities of gos and brine to recombine in the laboratary.

\subsection{GAS PRODUCTION, MEASUREMENT, AND ANALYSES}

The gas separation and metering at the Gladys McColl site is represented schematically in Exhitit 1.1. There are twa separatars operating in series. Gas and brine are separated in the first separator at pressures that are usually around the sales line pressure of $1000 \mathrm{psig}$. The brine then pases to the second, low pressure, separator where some additional gas liberated by the pressure drop is recovered. Gos remoining in the brine after the low pressure separator is put dawn the disposal well.

The opersting pressure of the low pressure separator is governed by two criteria. First the pressure must te high enough to inject the trine into the disposal well. There are no pumps to push the brine down the disposal well. The secand criterian is the gas buyer's requirement that the carbon diaxide content of the comingled high pressure and compressed low pressure gas must be less than ten percent. Lowering the pressure in the low pressure separotor increases the total recovery of hydrocarbans tiut also incresses the carbon diaxide content of the comingled sales gas.

\subsection{Gos Analyses}

Numerous gas samples have been collected and analysed over the years. The composition of the gas at every sample point depends on the pressure and temperature at that point as well as the fluids previously removed 


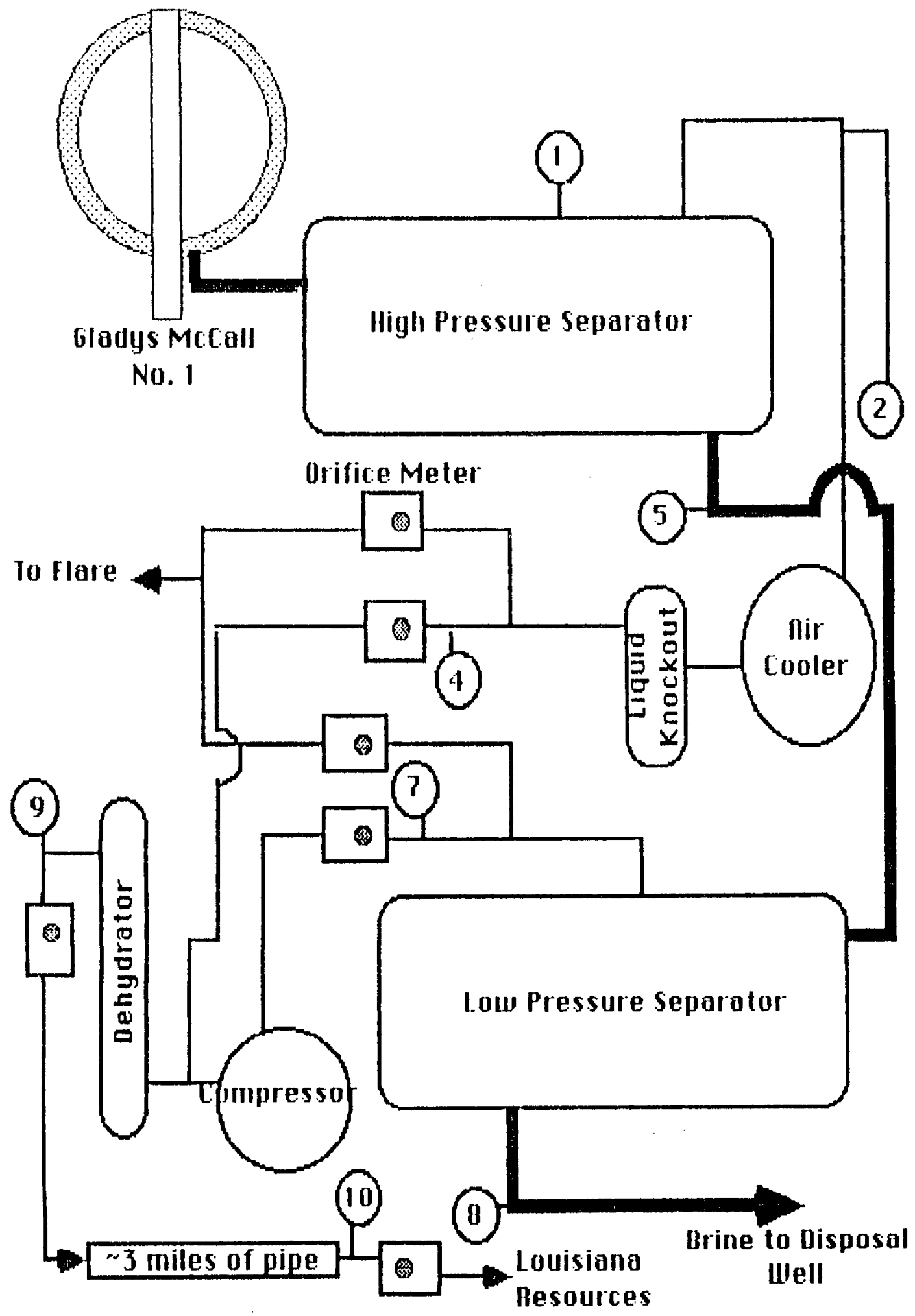

Exhibit 1.1 Gladys McCall Gas Separation Schematic 
from the gas stream. Appendix $B$ contains results of all gos analyses that we have found. They ore grouped by somple locotions thosen to foclitate dats interpretation for various purposes. The analyses reparted have teen performed by IGT, Weatherly Latoratories, or Petroleum Analyst, the. The latter laborgtory analyses samples far the gas buyer Luuisian Resources. inc). The natural gos liquids content, gravity, and hestung palue for all samples have been recalculated on a common basis since factors used by dif ferent latorataries are often not consistent. Note that heating value is tatulated for s base pressure of 14.73 psia wheress the notural gos liquids sre reported on the Louisiana pressure tase of 15025 peis.

Each sample locition is identified ty a number and a code word. In Exhicit 1.1 the somple locations are numbered. These numbers are also on the tables in Appendix E. Each sample location is discused telow

- Chaice 1, identified as GMITOFGAS, is gas obtained from the top of the first stage seporator. The gas ls sompled st the first stage separator pressure and brine temperature. This gos is at equilibrium with the onfe This gas is mast representative of what is being produced at a given moment from the well, because mast of the gas produced is first ansiable at that sample point.

- Choice 2, identified as GMllKELGGA, is gos attained from the gos line out of the first stage separator before the couler. This gas difers from Chnice 1 in that some coulung of the gas and associsted condensotion of water and natural gas liquids accurs as the gas mouse from the high pressure separator to the sample collection paint. Ths locaton is where kejey and Meriwether (USw) collect "cryocondensote" samples from the gas stream.

- Choice 4 identified as GMIMETRGAS, 10 gas obtained from a value on the side of the first stoge separgtar gas to sajes orifice meter. Analyses of this gos should tie used in the llowrate colculations for that orifice. This gos has been conled to near ambient temperature and the resultant hquids have been remaved. Gas samples obtained from the high pressure separstor $\mathrm{H}_{2} \mathrm{~S}$ sample foint are indistinguishable from gas obtained at the meter run. 
- Choice 5 , identified as GMIFLSGGAS, is actually obtained by collecting brine from the first stage separator before the dump valves. The brine is collected at the first stage separator pressure and temperature in steel cylinders. The brine is cooled and the pressure reduced to atmospheric. Gas exsolves from the brine. In normal operations, a portion of this gas would be recovered by the second stage separator and a portion injected with the brine down the disposal well.

- Choice 7, identified as GM2DRAGAS, is gas obtained at the second stage separator gas to sales orifice meter. This gas is at the second stage pressure and at a temperature usually near that of the brine. Analyses of this gas should be used in the flowrate calculations for that orifice. Gas samples obtained at the low pressure separator $\mathrm{H} 25$ sample point are similar to gas obtained at the orifice plate.

- Choice 8 , identified as GM2FLSHGAS, is gas flashed from brine collected at the second stage separator temperature and pressure. This gas is normally injected down the disposal well.

- Choice 9 identified as GMSALEGAS, is gas obtained after the first and second stage gas has been brought to sales line pressure, cooled, and had the water removed with a glycol unit. The sample location is near the sales gas or ifice meter.

- Choice 10 identified as GM_LASALE, is gas obtained at the custody transfer point near the road, roughly 2.4 miles from the Gladys McCall location. This gas is similar to Choice 9, but analyses of samples from this point by the buyer, Louisiana Resources Inc, are used for custody transfer considerations. These include verification that the gas meets contract specifications (such as water content, H2S content and less than 10\% carbon dioxide) and determination of BTU content.

\section{I.2 Gas Rate Measurement}

The direct measurements of gas production rates from the two separators and the comingled gas to sales are made with orifice meters. Each 
separator is equipped with separate orifice plates for gas flow to sales and for gas flow to flare. Portions of gas from each separator could be simultaneously sold and flared. The orifices are not equipped with block valves and bypasses. Thus, shut-in of production would be required for changing orifice plate size. In practice, sensitivity is adjusted by changing the span of the differential pressure transmitter, with the inherent degrading of resolution and accuracy for low rates.

The amount and composition of gas in the brine leaving each separator is periodically determined by measuring the amount liberated from a cooled brine sample when the pressure is reduced to atmospheric and analysis of that gas. The carbon dioxide content of recovered gas and of gas in brine sent to the disposal well is dependent upon whether scaling occurs. The formation of each molecule of carbonate scale is accompanied by formation of a carbon dioxide molecule.

\subsection{Orifice Metering}

The gas production rates reported from the Gladys McCall location are calculated by the operators with the use of a table for each meter run that is a function only of pressure and temperature. Multiplying the value obtained by interpolation of the table by the square root of the differential pressure then yields the reported gas rate. These tables were provided by a consultant during 1984. Notations on the tables reveal that the following values were used to calculate them:

Dimensions:

$$
\text { HPSep LPSep Sales }
$$

Pipe I.D., in.

Orifice bore, in.

2.626

.75

18.957

1.3

.015
2.626

.375

22.832

1.3

.015
2.067

.625

Gas Properties:

Molecular weight

Specific heat ratio viscosity, $c p$.

Dry Gas Gravity (ideal) calculated from the above molecular weight $\quad .6545$

19.407

1.3

.015 
This field procedure assumes that the only variables in the orifice equation for each meter run are the measured pressure, differential pressure and temperature. But, in practice, the orifice equation has multiplicative factors that are dependent upon the composition of the gas being metered. The most significant is the gas gravity factor, which is the inverse of the square root of the gas gravity. A smaller composition dependence is in the supercompressibility factor (inverse of the square root of the compressibility or $z$ ) for deviation from ideal gas behavior.

Correction of metered gas rates for water vapor is very significant for the meter runs on the low pressure separator. At a temperature of 260 degrees Fahrenheit, the vapor pressure of water is 35.4 psia. Thus, at a separator pressure of 400 psia, roughly 9 percent of the gas passing through the orifice plate is water vapor which is condensed and removed from the stream before the gas is sold. The effect of this water vapor upon gas gravity and supercompressibility should be taken into account in deducing total gas flow rate from the orifice meter and then correction should be made for the water to be condensed.

When IGT installed the computer data aquisition system on the Gladys McCall site in 1986, the real, dry gas gravities selected in an effort to match operator reported rates were $0.6562,0.727$ and 0.670 for the high pressure separator, low pressure separator and sales gas meter runs respectively. Resolution of differences of up a few percent between operator reported rates and rates from the digital system was not practicable due to lack of details on the calculations that produced the tables used by the operators.

The actual dry gas gravity depends primarily on the pressure of the separators. The higher the separator pressure, the lower the gas gravity. This function is clearly shown in Exhibits 1.2 and 1.3, which presents the gas gravity calculated from analyses of gas samples collected at the orifice meters on the high and low pressure separators (choices $4 \& 7$ ) at various times over the life of the test. The dry gas gravity will also be affected by the brine temperature and, for the low pressure separator, by the operating pressure of the high pressure separator. 


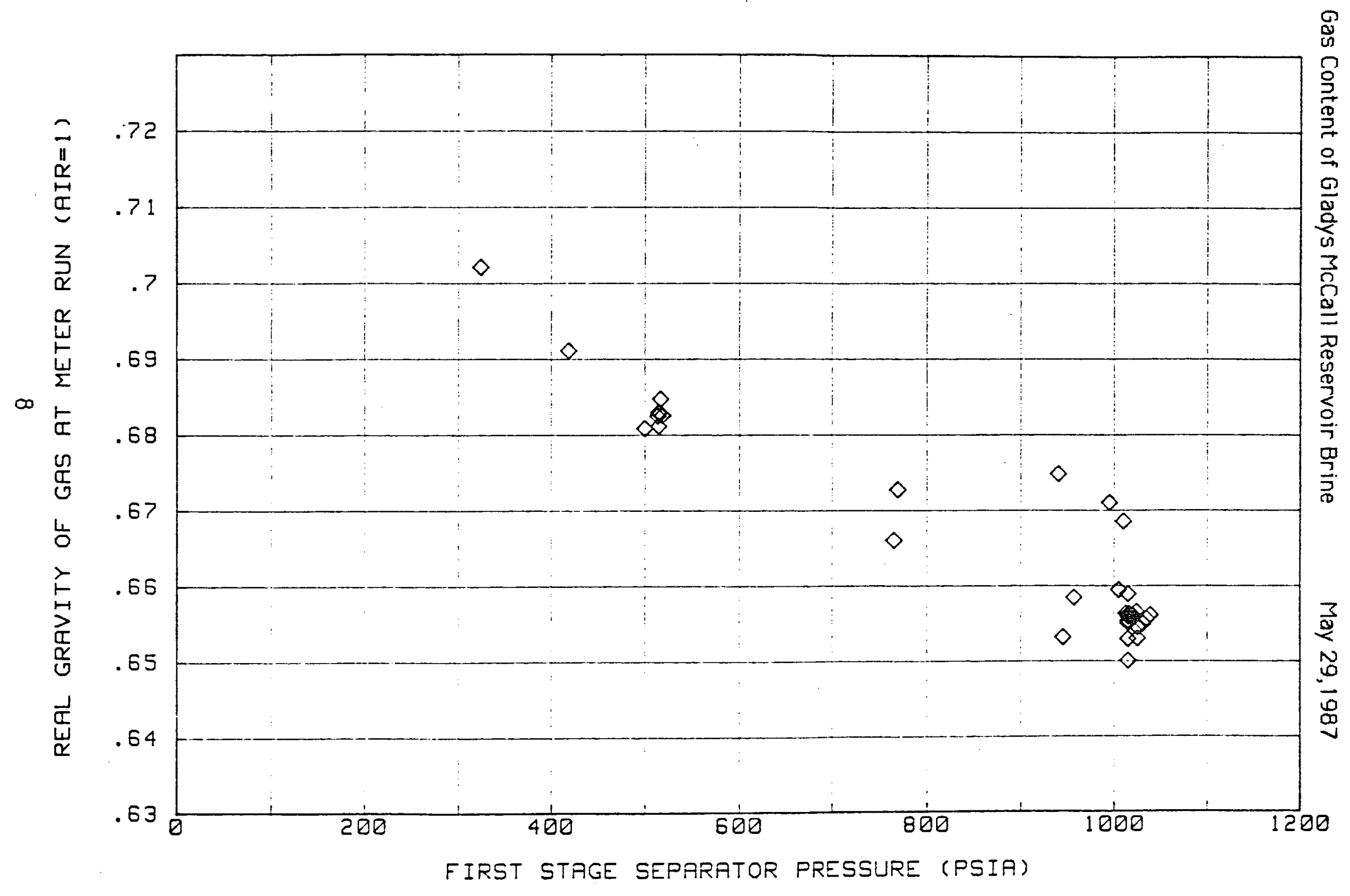

Exhibit 1.2 First Stage Separator Gas Gravity vs. Pressure 


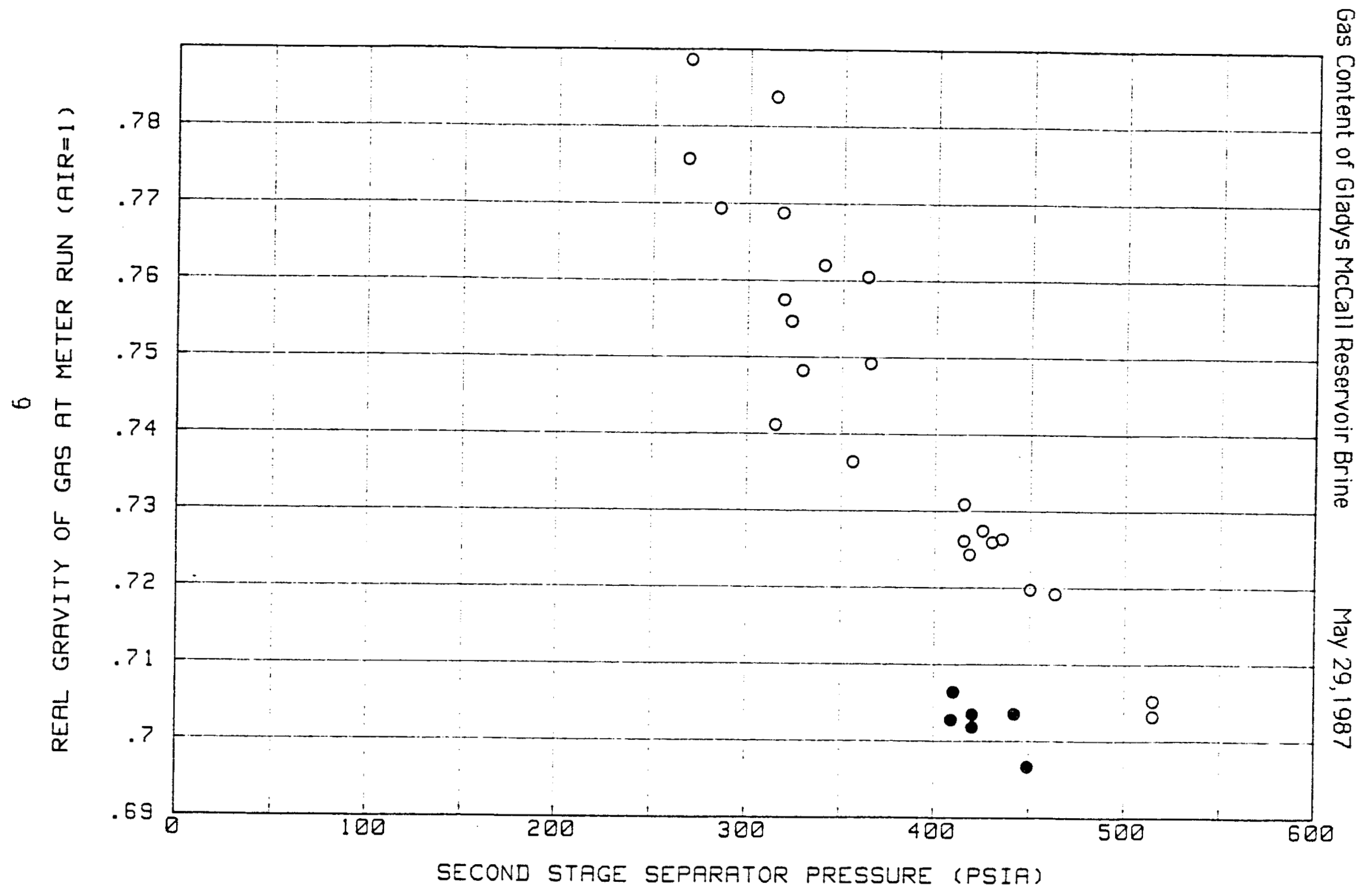

Exhibit 1.3 Second Stage Separator Gas Gravity vs. Pressure 
On April 13-14, 1967, when the high pressure separator was st 515 psia and the low pressure separstor was at $400-450 \mathrm{psia}$, low pressure separotor gos grovity wos lower than would be expected at that pressure. These data points are tlackened in Exhibit 1.3 to differentiate them from the remaining samples. The extent to which the lower grovities are due to undocumented transfers of gas from the high pressure separotor to the law pressure separator through a bypass line is not dear. These transfers were needed to maintain control of the level in the law preseure separatar.

With the actual gas gravities differing from the assumed gas gravity the calculated gos flow rates will be in error. The gravities are correct only if the high pressure separator is opersted st 1000 psis and the low pressure separator is kept at 420 psic. Exhibit 1.4 shows the error in the reported gas rates at several operoting pressures.

Exhibit 1.4, Error in Gas Rate Colculations Gased an

The Different Gas Gravities at Various Pressures

$\begin{array}{ccc}\text { Pressure } & \begin{array}{c}\text { Gos Gravity } \\ \text { High Pressure Seporatar }\end{array} \\ & 0.663 & 2.0 \% \text { high } \\ 500 \text { psia } & 0.669 & 1.0 \% \text { high } \\ 750 \text { psia } & 0.656 & 0.0\end{array}$

Low Pressure Separator (HF Sep 1000 psi)

$\begin{array}{llr}300 \text { psia } & 0.775 & 3.2 \text { g high } \\ 400 \text { psia } & 0.732 & 0.3 \% \text { high } \\ 500 \text { psia } & 0.708 & (-1.3) \% \text { low }\end{array}$

\subsubsection{Gos in Brine}

IGT uses an algarithm based an thase of Garg and Blount to calculate the amount of gos remoining in the brine after the seporotor. The validity of this algorithm has been demonstrated on numerous DOE wells. Exhibit 1.5 presents the amount of gos recovered during brine floshes performed by IGT and weotherly on brine from both the first and second stage separators versus the separator pressure. The thatnt of go ieit in the brine is 


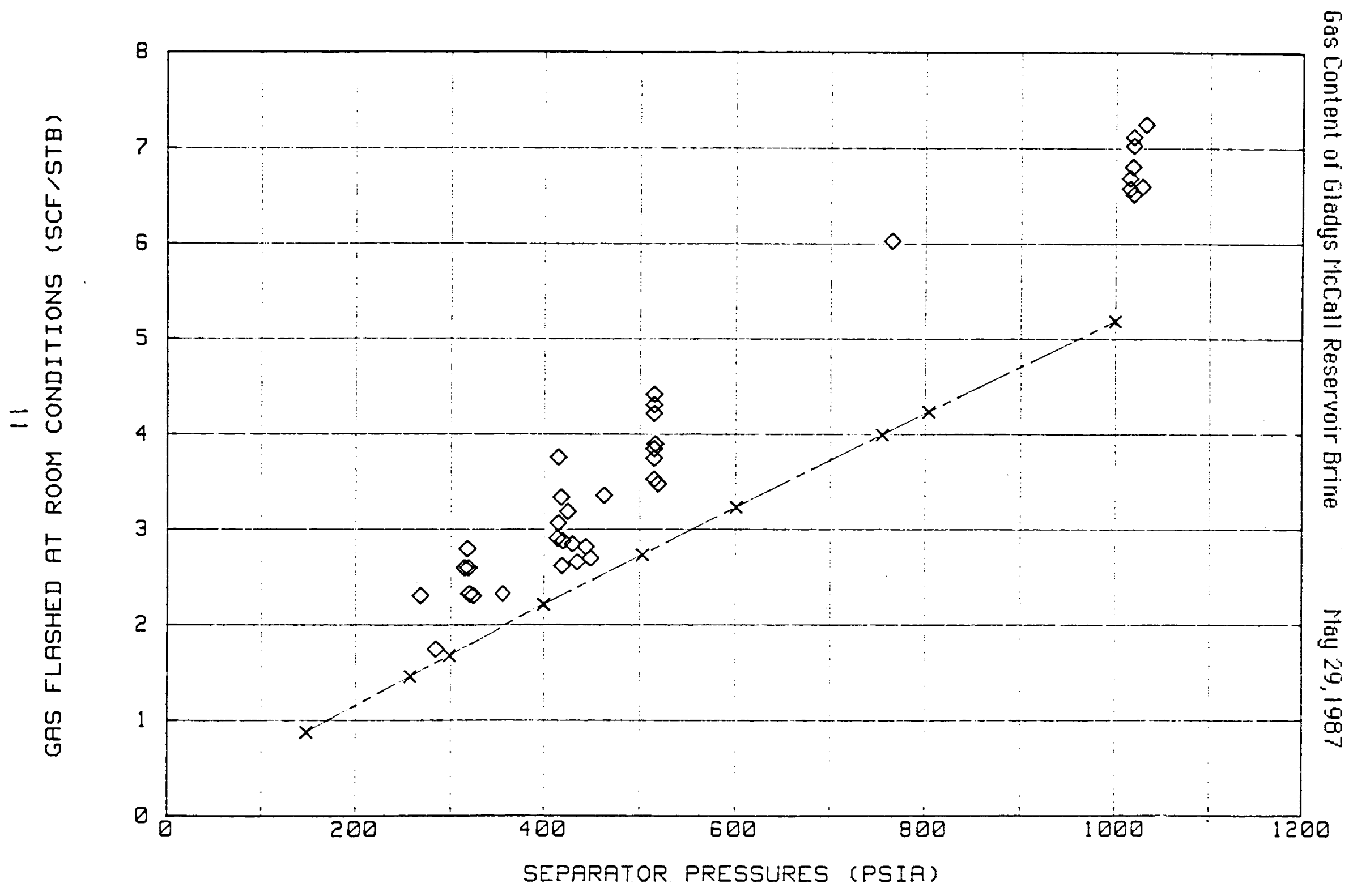

Exhibit 1.5 Gas Left in Brine vs. Separator Pressure 
dependent an the pressure of the separator. The temperature would also have a much smaller effect on gos content, but the Gladys McColl system has remained relatively isothermal.

The diamonds in Exhibit 1.5 are gas liberated by reducing the pressure on separotor brine to atmospheric pressure (flashing) by IGT and weotherly. The " $X$ "s represent calculated values which are low by about $30 \%$. Recall that the algorithm is based on methane solubility in brine.

Exhibit 1.6 presents the METHANE content of the separator brine versus the METHANE PARTIAL PRESSURE in the separator. The " $x$ "s are the same as in Exhibit 1.5, representing the IGT algorithm for calculating ges content in brine after the separator. The agreement between the two is excellent. Methane content of brine of ter the seporator is consistent with Henry's Law in that it deviates little from a linear dependence. For every 100 psi of methane partial pressure, 0.56 SCF/STB of methane will remain in the brine. This compares to values of $0.62 \mathrm{SCF} / \mathrm{STB} / 100 \mathrm{psi}$ for the wainoco P.R. Girouard $* 1,0.60$ SCF $/ S T B / 100$ psi for the Pleasant Bayou *2, and 0.53 SCF/STB $/ 100$ psi for the HO\&M Prairie Canal *1.

Exhibit 1.7 is a plot of ethane content of disposal brine versus the ethane partial pressure in the separator. Again, there is a simple linear relationship that follows Henry's Law, with 0.0040 SCF ethane/STE/psi, which compares favorably with $0.0038 \mathrm{SCF}$ ethane/STB/psi ethane partial pressure at the HO\&M Prairie Canal $* 1$ Well. Note that these values are yalid ONLY FOR METHANE AND ETHANE PARTIAL PRESSURES, not separotor pressure.

These simple relationships, which do not change with flowrate, indicate that the separators are at equilibrium and the only way ta recover mare methane is lower the separator pressure.

\section{I.3 Gas Production and Gas/Brine Ratios}

MONTHLY PRODUCTION REPORTS have been produced in the field in a consistent manner since the start of testing of the Gladys Mcciall well. Daily production and pressures are summarized on a single line on each of 


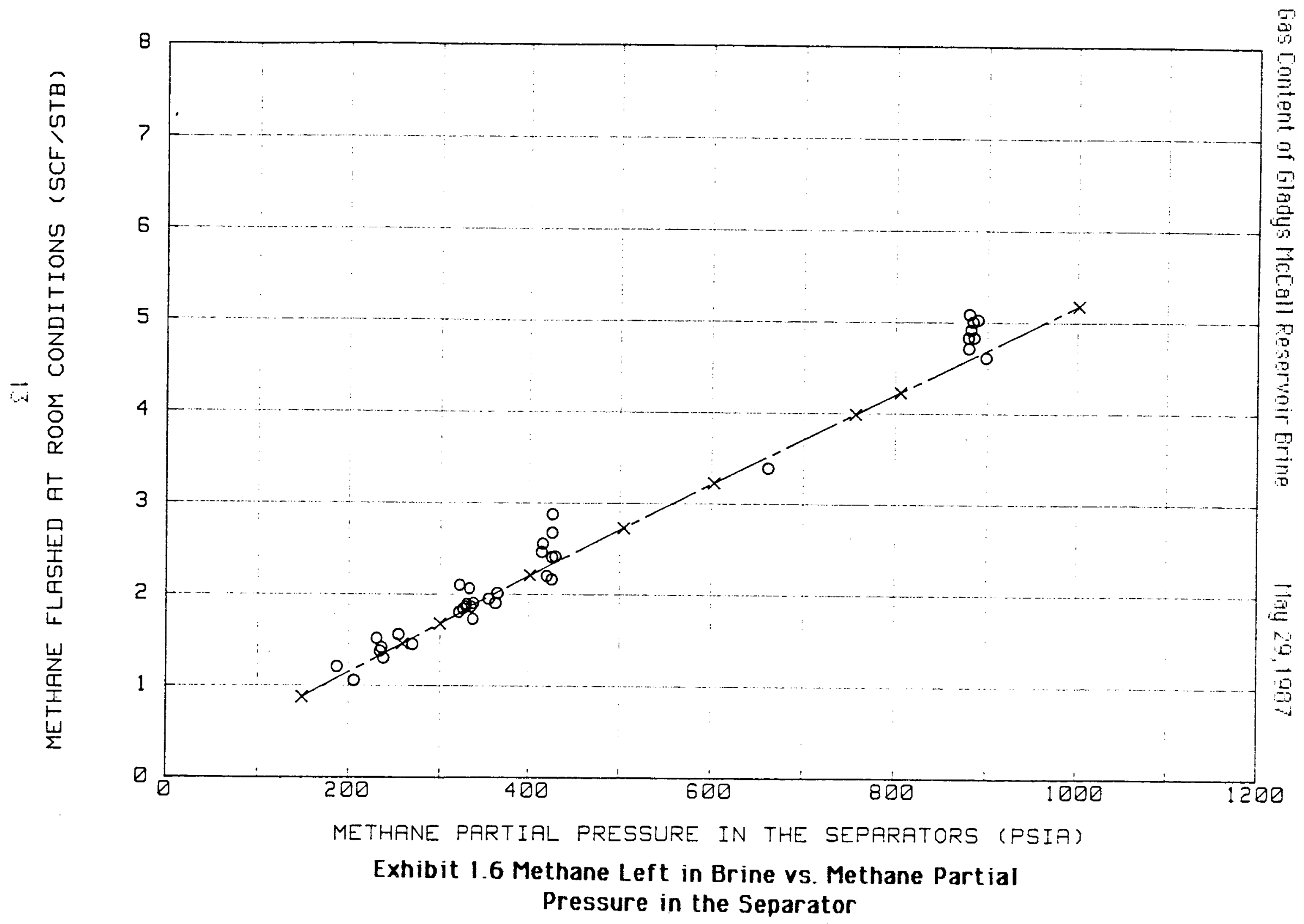




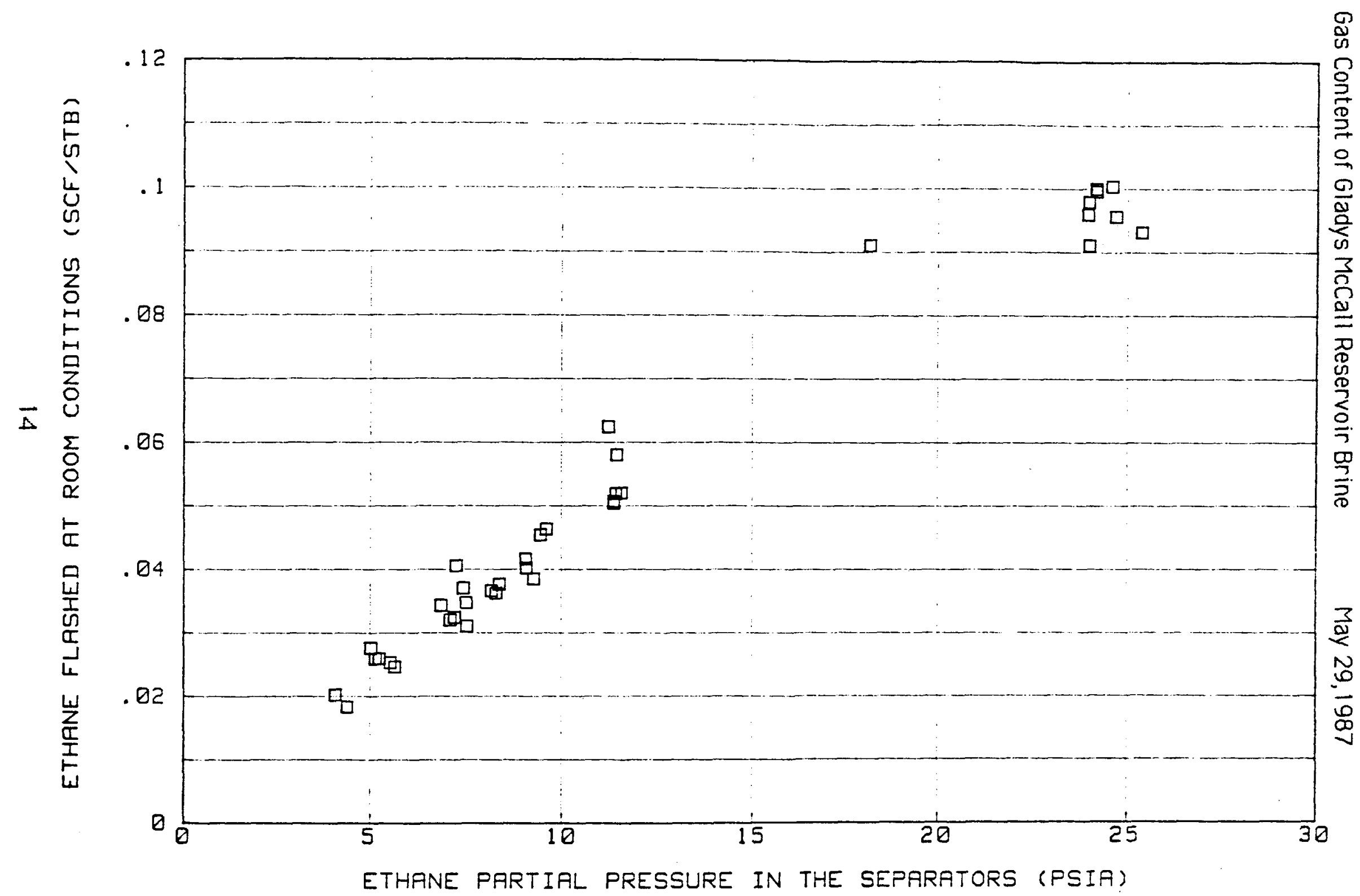

Exhibit 1.7 Ethane Left in Brine vs. Ethane Partial Pressure in the Separator 
the two pages of the monthly report. IGT has entered these data into a computer and augmented the data by using our algorithms to convert brine rate to stock tank barrels per day (STB), to calculate gas content of brine to the disposal well, and to calculate flowing bottomhole pressure

First, IGT calculates a brine rate in terms of stock tank barrels of brine per day (STB/D) from the reported separator barrels per day operator reported gas production rates are not adjusted for gas gravity or changed in any manner. Next, the computer calculates the amount of gas remaining in the brine after the second separator. By adding the gas recovered in the first separator, the gas recovered in the second separator, and the gas remaining in the brine after the second separator, all of the gas produced from the reservoir is accounted for. The result of this calculation procedure is called the perforation gas.

Cumulative perforation gas production versus cumulative brine production from these calculations is presented in Exhibit 1.8. The overall gas to brine ratio taken from the slope of the line is 28.8 SCF/STB.

\subsection{Total Gas Measurement}

The partitioning of gas between separator meter runs and brine to the disposal well is dependent upon separator pressures. Thus, deducing whether the gas content of each barrel of brine passing through the perforations into the wellbore has changed with time requires summing of two or three gas volume and composition measurements to deduce total gas content of produced brine at each time.

Several analyses are needed to define the total produced gas. The easiest method of determining this value is by measuring the first stage separator gas and the gas remaining in the brine after the first stage separator. In terms of the gas analyses in the Appendix, Choice 1 (or 2 or 4) with Choice 5. An equally acceptable alternative is to replace Choice 5 with Choice 7 and Choice 8.

The gas analyses are combined by weighting each by the gas to brine ratio at each sample point. The first stage separator gas generally comprises 


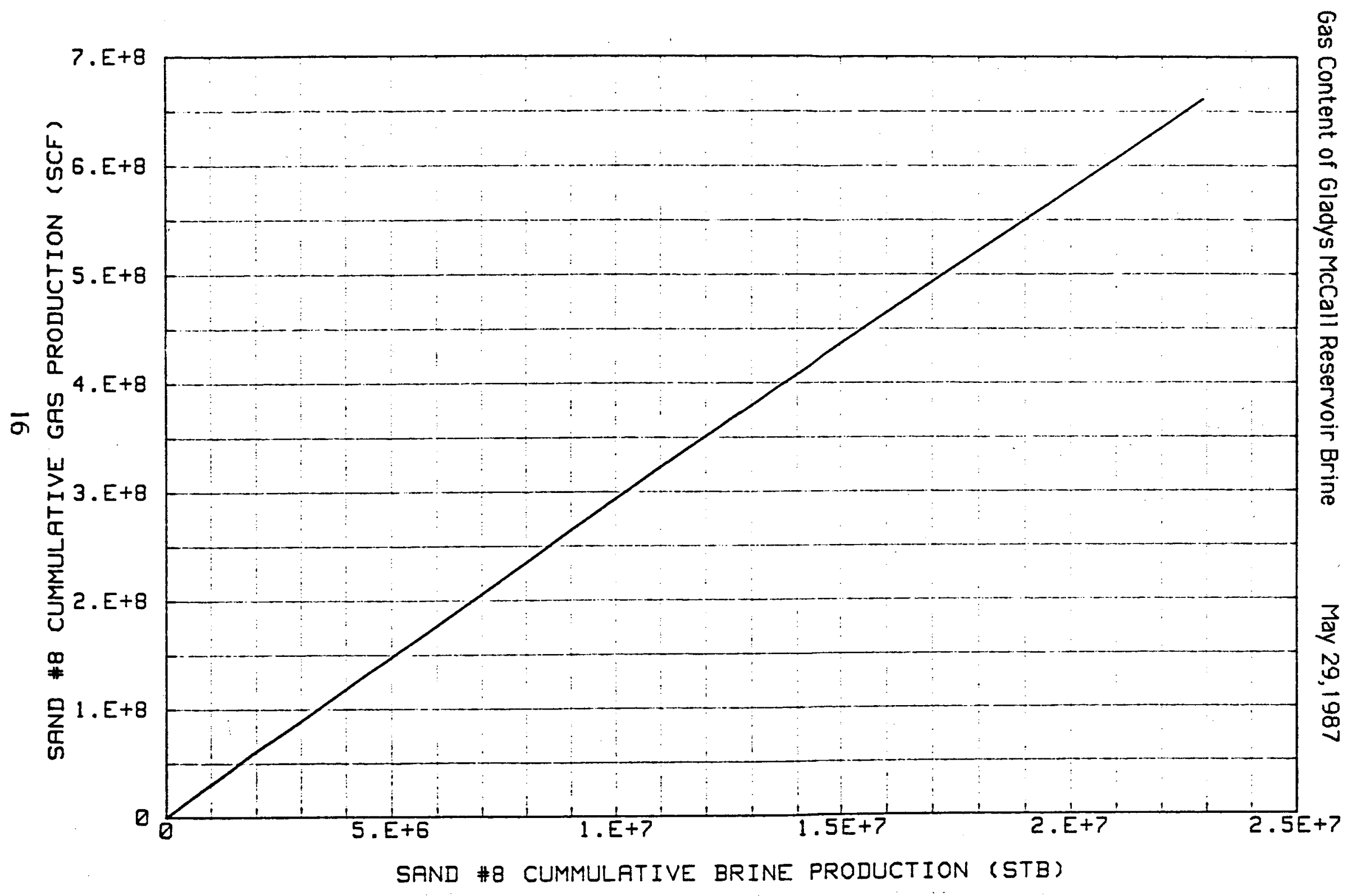

Exhibit 1.8 Cumulative Perforation Gas Production vs. Cumulative Brine Production 
23 SCF/STB out of a total of 29 SCF/STB, so the composition of the first stage gas greatly effects the composition of the total gas. In contrast, a flash of the second stage separator brine generally provides less than 3 SCF/STB. So even though the composition of this flashed gas is very different than that of the first stage gas, it does not overly affect the calculated composition of the total gas.

In more detail, for each sample point, the procedure is to multiply the mole fractions of each gaseous species by the appropriate gas to brine ratio. This will result in cubic feet of methane, ethane, propane, etc. per barrel of brine. Then, the contributions from sample points are added until all of the produced gas is counted, as described above. Finally, the gas/brine ratio for each gas component is divided by the sum of all gas to brine ratios to get the composition of the total gas.

A compilation of all total gas measurements made to date are provided in Appendix $C$. In cases where the first stage separator brine was flashed, the second stage separator gas is not needed to calculate the total gas, and -.10 is inserted in the gas composition table to differentiate no analysis from a measured zero concentration.

\subsection{GAS CONTENT OF RESERVOIR BRINE}

If a geopressured geothermal reservoir is not saturated with gas, the possibility of economically viable production has not been established. Conversely, if the reservoir is saturated with gas, there is a distinct possibility that free hydrocarbons exist somewhere in the reservoir. If these free hydrocarbons cone into the well, such as occurred on the Lear G.M. Koelemay * 1 well, the production economics improve dramatically.

Laboratory recombination of samples of separator gas and brine that were collected October 8,1983 , after only a day of production from sand * 8 , gave a bubble point of 9200 psia. This is much less than the initial reservoir pressure of 12,783 psia and indicated that the reservoir brine was not saturated with natural gas. The primary uncertainty in this conclusion was whether rate measurement problems had resulted in laboratory recombination of the wrong gas/brine ratio. 
The data from long term testing makes possible use of several other tests and analytical techniques to address the question of saturation of reservoir brine. These tests involve both gas to brine ratio measurements and chemical composition measurements. The preponderance of data leads us to conclude that the reservoir was not origionally saturated with gas. The reservoir may even now be drawn down to below the bubble point only in the near wellbore area. The data and interpretation leading to these conclusions are discussed in the following sections.

\subsection{P-V-T Studies}

The $1983 \mathrm{P}-\mathrm{V}-\mathrm{T}$ study (report is Appendix A) was performed by the same personel and laboratory facility as similar prior studies of samples from Wells of Opportunity. The prior work had eliminated many "bugs" from the very tricky and tedious procedure and achieved good agreement with other laboratories studying solubility of natural gas in brine.

Exhibit 2.1 presents the the gas to brine ratios from Appendix $A$ in terms of SCF/separator barrel and SCF/STB and the resulting bubble point pressures. The right hand column is methane solubility calculated from equations developed for DOE by C.W. Blount and his students.

Exhibit 2.1, Weatherly P-V-T Recombination Data

---GAS TO BRINE RATIOS---

SCF/sep. barrel SCF/STB

10.01

15.00

18.00

20.00

25.01

$31.9^{+}$
14.36

19.64

22.82

24.94

30.25

37.5 $\begin{array}{cc}\text { Bubble point } & \text { BLOUNT SOLUBILITY* } \\ \text { (psia) } & \text { SCF/STB }\end{array}$

15.85

20.68

23.64

25.67

30.30

35.84

+ extrapolated

* Calculated for 294 Deg F. and 95,000 ppm NaCl 
Due to the hydrostatic pressure of brine in the well, the only entries in Exhibit 2.1 descriptive of credible producing conditions are the three highest pressures. The agreement between recombination gas content and laboratory solubility of pure methane in pure $\mathrm{NaCl}$ brine is surprisingly close at bubble point pressures of 6780 and 9200 psia. Unfortunately, page 12 of the $P-V-T$ report in Appendix A reflects the authors questionable extrapolation to 31.9 SCF sep.gas @ 15.025 psia \& 60 deg F per BBL. sep.water @ 500 psig \& 268 deg $F$. at reservoir pressure that is on page 20 of the report. Correcting to atmospheric pressure and 60 deg $F$ and adding gas flashed from the separator brine results in the high value of 37.5 SCF/STB for gas solubility in reservoir brine. The authors extrapolation on page 23 of the report (to 35.8 SCF/STB) is in excellent agreement with expectations based on pure components.

As previously mentioned, one concern regarding the $1983 \mathrm{P}-\mathrm{V}-\mathrm{T}$ work is whether an incorrect ratio of separator gas and brine was recombined due to problems or errors in flow rate measurement. The oil accumulation in the separators that became apparent more than a year after the start of production provides another concern. It is virtually impossible to collect and recombine samples of three fluid phases (gas,oil \& water) in the correct proportions. Also, careful work in the same laboratory had previously revealed that trace amounts of oil precluded reproducible measurement of the gas/brine bubble point for samples from the Lear G.M. Koelemay well.

\subsection{Changes in the Produced Gas to Brine Ratio}

Weatherly's P-V-T data suggest that for every psi the brine is below the bubble point, 0.002 SCF/STB of gas will come out of solution. This gas will be trapped in the portion of the cone of depression that is below the bubble point pressure until the critical gas saturation of about 3\% of the pore volume is reached. The volume of this portion of the cone of depression will increase with time and a only a small portion of the gas being trapped will flow. The produced gas to brine ratio is expected to be reflect the solubility of gas at the pressure that exists with a few feet of the wellbore rather than the gas content of original reservoir brine. 
Exhibit 2.2 is a plot of the perforation gas to trine ratios for which daily perforition gas rotes have been colculated as set forth in section 13 to include an estimate of gas remoining in trine to the disposal well. The difficulty in messuring the gos rotes during the first portion of the test is opporent as scotter in values for the gosibrine rotio. Ey late 1964 the problems had been largely owercome and the dota appears good. Whether the drops in the gos to water ratio during the third and fourth quarters of 1985 are due to the bottomhole pressure folling below the butbile foint pressure is conjectural but is within the realm of paseibility. The first successful imhibitar pill had been pumped. Sustaned brie rates were higher than had previousily been practicable and flowing bottomhole pressure was was correspondingly lower (roughly 9500 psi)

This slight decline made the small charge in the slope of the cumulative gas versus cumulative brine plot (Exhitit 1.6) at about 10 millian tarrels of trine. The change in the gas to brine ratio is very small. We estimate that there has been less thon 1 SCF/STE decline since the beginning of the test. This is consistent with the bot tomhole pressure folling roughly 500 psi below the bubble point pressure.

Calculated bottombile pressures during the third quarter of 1985 ranged from 9700 psis to atout 9400 psia. This indicotes that the butble point pressure is in the some range. That range is in good agreement with the 9200 psio from the $P-V-T$ dets.

On the other hand, if the reservoir brine had been saturated with natural gis at original reservoir pressure, the tropping of exsolved gos in the reservoir would have been expected to reduce the surface deduced perforation gos to brine ratio by about 4 to 5 SCF/STE aver the time spon shown in Exhibit 2.2 .

\subsection{Changes in the Produced Gas Composition}

The natural gas in this reservoir is a mixture containing methare, ethane, propane, butanes, carbon diaxide, and other gases. Eecouse the individus components have different solubilities, o gas phose in equilibrium with 


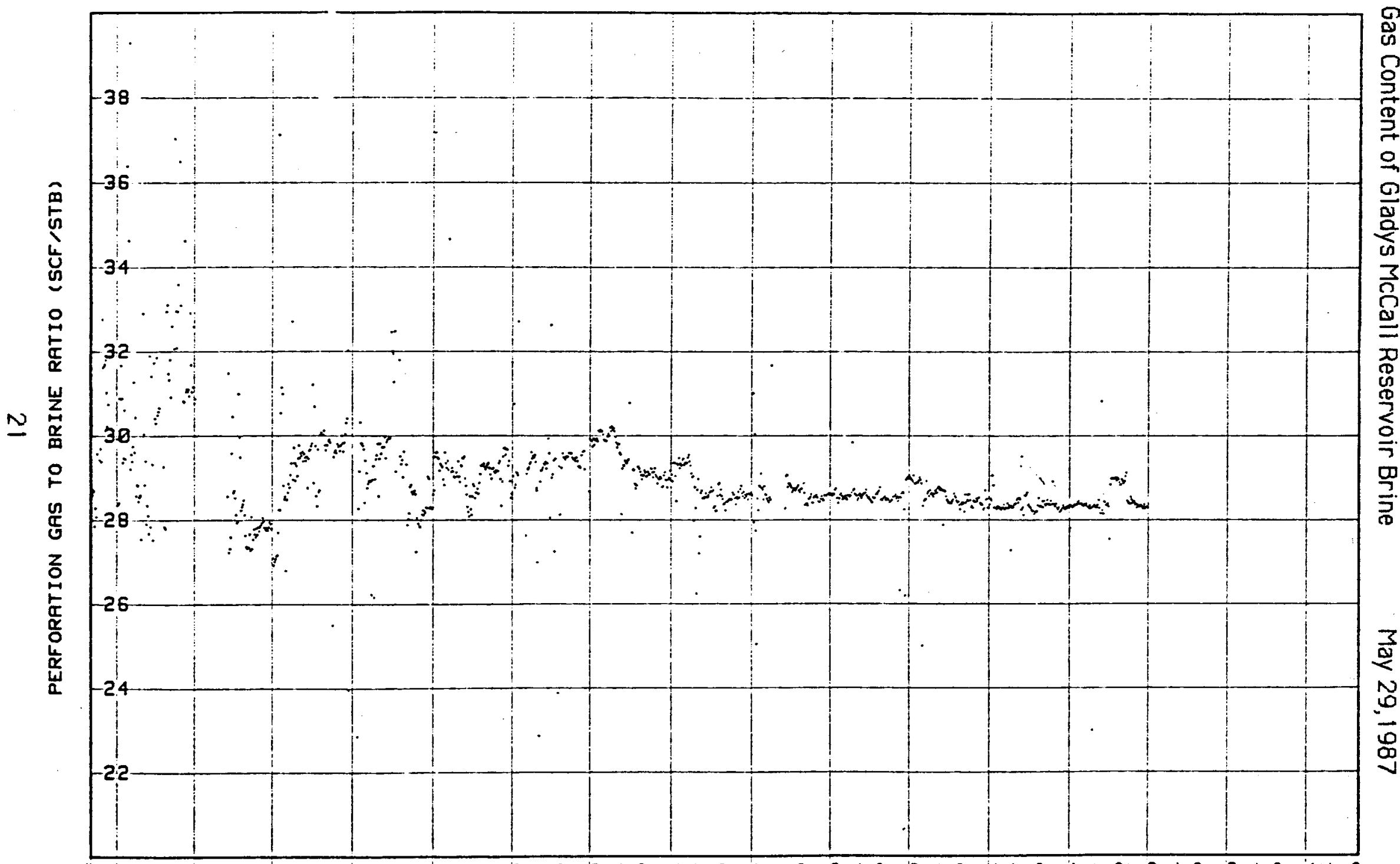

1st Otr2nd Otri3rd Otrith Otrlst Otrind Otri3rd Otr4th Otrist Otrind Otri3rd Otrith Otrist Otrind Otri3rd Qtrith C $1984|1984| 1984|1984| 1985|1985| 1985|1985| 1986|1986| 1986|1985| 1987|1987| 1987 \mid 198$

Exhibit 2.2 Perforation Gas to Brine Ratio vs. Time 
trine will have a diferent composition than the gas dissolved in the trine The heavier hydrocarbon/methane ratios are much higher in the free gas than in the dissolved gas. The effect becomes more pronounced as stin! heavier hydrocartons are examined. For instance, the fropone/methane ratio contrast is greater than the ethane/methane ratia contrast.

This effect is demonstrated in Exhibit 2.3, which presents data from s differential liberstion study perfarmed by hestherly Laborstaries as a port of the $P-y-T$ study covered by the report in Appendix $A$. Gas and trine from the Glodys mcCall well were recombined at 30.46 SCF/STB. The butble point pressure was 9200 psia. This fluid is representative of the reservoir brine priar to production. The pressure an the brine was reduced until a bubble large enough to sample had exsolved from the trine. This butble was then remaved and the pressure was lowered still further until onother bubble could be sampled.

Eshibit 23 Gge Libergted During P-V-T Differentigl Liberition

\begin{tabular}{|c|c|c|c|c|c|}
\hline $\begin{array}{l}\text { Pressure (psia) } \\
\text { Gas/Brine }\end{array}$ & 9200 & 6000 & 4000 & 2000 & 15 \\
\hline Rotio (SCF/STE) & 30.46 & 26.41 & 21.77 & 1466 & 0 \\
\hline & Solution Gas & \multicolumn{4}{|c|}{ Gos Liberated From Solution } \\
\hline & -...... & & & & \\
\hline Carton Diayide $(R)$ & 14.48 & 4.20 & 3.10 & 3.87 & 24.79 \\
\hline Methane $(P)$ & 82.45 & 89.03 & 91.74 & 92.34 & 7393 \\
\hline Ethane $(8)$ & 2.22 & 4.34 & 3.50 & 2.75 & 1.06 \\
\hline Propine $(8)$ & 0.48 & 1.53 & 0.99 & 0.63 & 0.11 \\
\hline Butanes $(8)$ & 0.14 & 0.40 & 0.32 & 0.16 & 000 \\
\hline Pentanes $(R)$ & 0.03 & 0.12 & 0.06 & 003 & 000 \\
\hline$c .6+(\mathbb{R})$ & 0.20 & 0.38 & 0.29 & 0.20 & 0.11 \\
\hline
\end{tabular}

The butble of gas that was remaved from the $P-Y-T$ cell and analyed would be tropped in the reservair during narmal production. This gas is richer in the heavy hydrocorbans than the original solution gas. At the same time, the gas remaining in solution in the trine, and produced up the wellbore, would become slightly depleted in ethane and heavier hydrocarbons as reservoir pressure was reduced below the bubtle point. 
Exhibit 2.4 presents the ethane/methane and propane/methane ratios in the total gas composition as described in Section 1.4. These values suggest that the reservoir may have been below the bubble point by December of 1985. At that time the hydrocarbon ratios were clearly below those at the start of the test.

We can estimate the change in solution gas composition as the pressure drops below the bubble point. For a 500 psi drop from a bubble point of $9200 \mathrm{psi}$, approximately 1.0 SCF/STB of gas should have been exsolved and trapped in the reservoir. Using the gas compositions in Exhibit 2.3, and assuming that all of the exsolved gas is trapped in the reservoir, we can calculate that the ethane content of the produced (solution) gas should drop from $2.22 \%$ to $2.15 \%$. The propane content should drop from $0.480 \%$ to $0.444 \%$. The ethane /methane ratio should drop from 0.269 to 0.261 , and the propane/methane ratio should drop from 0.0058 to 0.0054 . These changes are about as observed between the 1984 samples and the 1986-1987 samples.

The gaps of more than a year between total gas measurements preclude interpretation of Exhibit 2.4 in terms of bubble point. Some of the gaps in time were examined by making a similar plot (Exhibit 2.5) from analyses of samples from the first stage separator at times when the pressure was near to $1000 \mathrm{psi}$. Overall trends of the two plots are similar but they do not provide resolution of the question as to whether the change during 1985 was due to dropping below the bubble point or due to changes in the source of brine. The latter possibility cannot be ignored. Oil accumulation in the separators began early in 1985 and changes in the concentrations of some species in solution in produced brine changed between February and May, 1985. The most notable was an increase in barium concentration from about $100 \mathrm{mg} / 1$ to about $500 \mathrm{mg} / 1$.

\subsection{The IGT Bubble Test}

During tests of Wells of Opportunity that produced gas saturated brine (G.M. Koelemay, Riddle-Saldana, and Prairie Canal wells), IGT observed that sudden increases in production rate were accompanied by a transient 


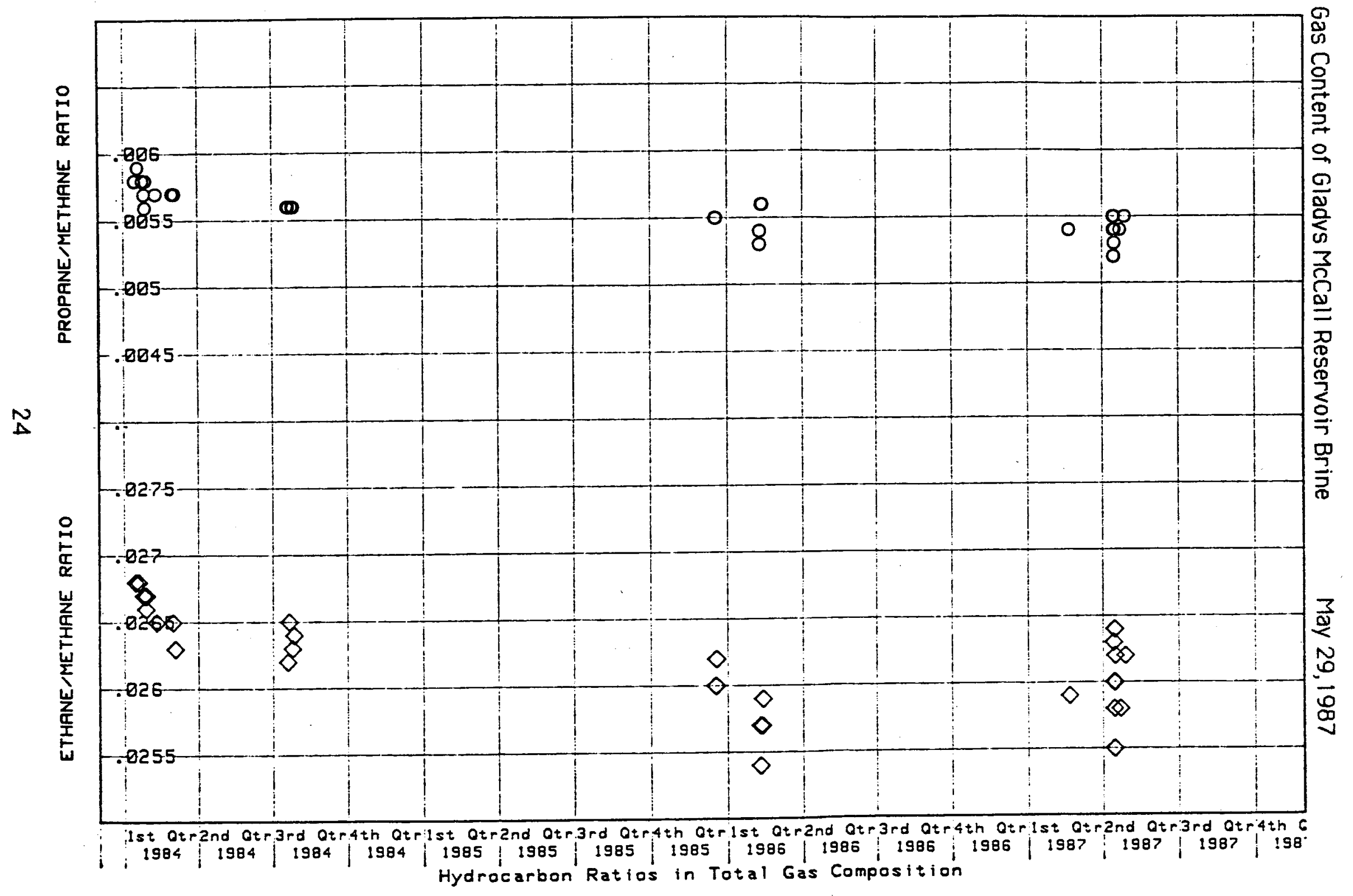

Exhibit 2.4 Ethane/Methane and Propane/Methane Ratios in the Total Produced Gas vs. Time 


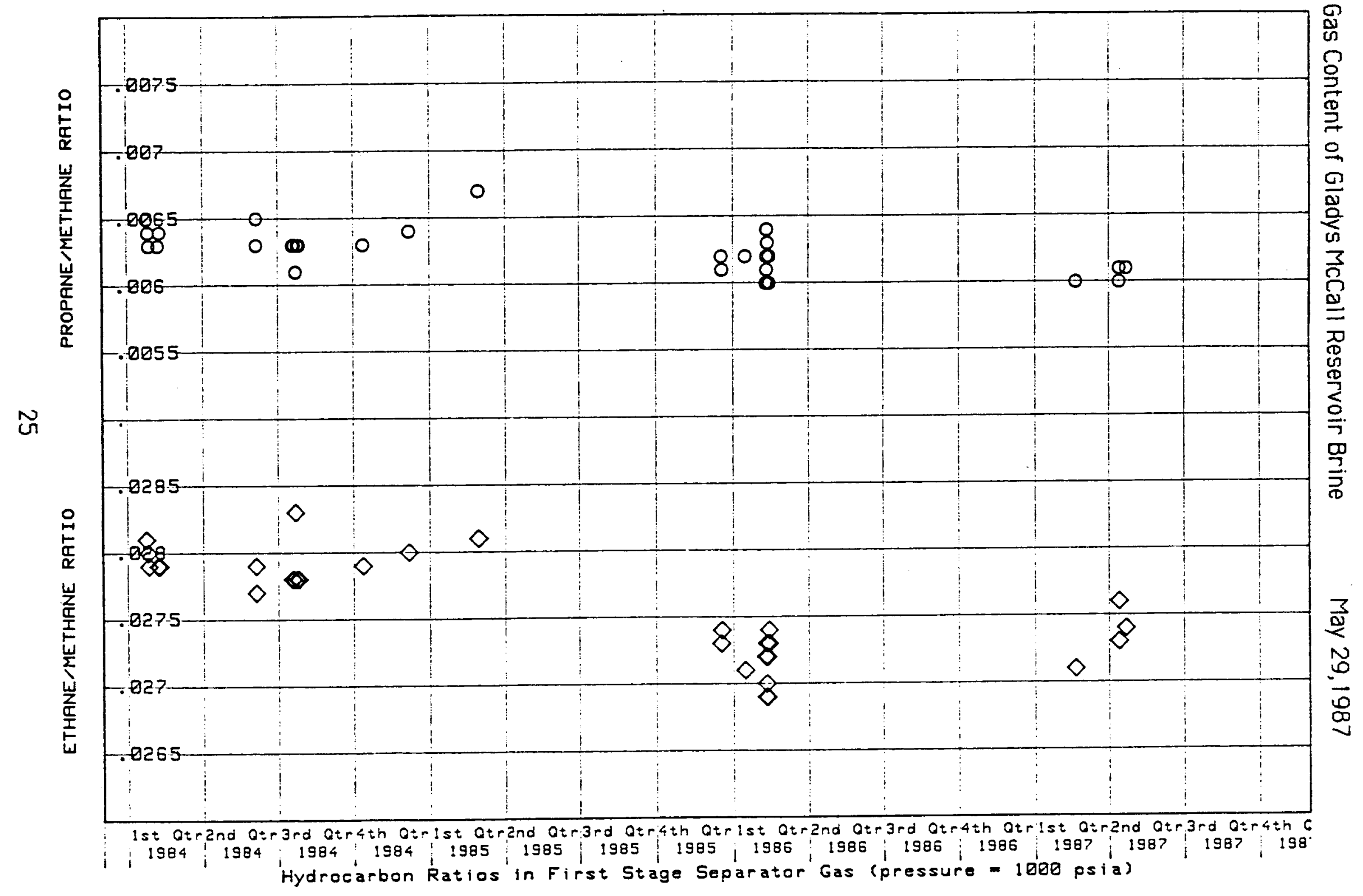

Exhibit 2.5 Ethane/Methane and Propane/Methane Ratios in the First Stage Separator Gas (Pressure $=1000$ psi) vs. Time 
"bubble" of natural gas having a duration of 10's of minutes. During the "bubble", produced gas/brine ratio was higher, natural gas liquid (NGL) content of the gas was higher, and carbon dioxide content was unchanged relative to steady-state production of gas saturated brine. Understanding of the bubble was found in the phenomena described above.

IGT adopted the procedure of carefully monitoring gas rates and composition following a step increase in drawdown as a "bubble test" to determine whether the flowing bottomhole pressure was below the bubble point pressure of reservoir brine. Or, in other words, to determine whether free gas was in pores near the wellbore.

Two bubble tests have been performed at the Gladys McCall well. The first was on Febuary 12, 1986 and the second was on April 14, 1987. Both suggested that the bottomhole pressure was below the bubble point pressure but that the amount of free gas in pores at near the critical gas saturation was very small. Details of the procedure, the test results, and interpretation are provided in the sections below.

\subsubsection{Physical Phenomena That Cause The Bubble}

As observed in Section 2.3, as brine pressure drops below the bubble point pressure, a portion of the gas is exsolved. This gas is much richer than the gas remaining in solution. Furthermore, this gas is trapped in the reservoir until the gas phase is continuous. The gas saturation needed to form a continuous gas phase is termed the "critical gas saturation". There is little data available on critical gas saturation, but the value is assumed to be about 3\% of the total pore volume (National Petroleum Council, 1980). Data from the P-V-T study indicate that the Gladys MCCall reservoir pressure would have to drop to below 2000 psia before gas would occupy $3 \%$ of the pore volume in the entire reservoir. But, in the area immediately surrounding the wellbore, brine being produced experiences large pressure gradients associated with brine converging on the wellbore and perforations.

As the BOTTOMHOLE PRESSURE drops below the bubble point pressure, gas exsolves near the wellbore. Gas saturation near the wellbore increases as 
fresh brine sweeps through the high pressure grodient region. leowing its small gos phase contribution. The gos soturation will increase until the critical gos soturation is reached. Thereater. any gis exsolung from solution will rase the saturation above critical and result in an equally small amount of free gas production up the wellbore. The reserboir wolume at the critical gas saturation will increase os the pressure dechnes but will always te a yery small fraction of the total reservoir golume under sny reasonable production scenario. Production of free gas from the high pressure gradient region near to the wellbore whl be hidden by exsolution of gos furthur out in the reservoir.

One condition wherein production of previcusly trapped free gos will be noticed is temporary in nature and constitutes $16 \mathrm{~T}$ 's "butbile test". If the weil hod been flowing at a steady rate and had buit up critical gas saturation near the welltare. a sudden drap in the bottambole preseure would couse the gas to expand. The amount of expansion will depend on the drop in the bottomhole pressure. For example, if the bottombale pressure orups from 9500 psis to 9300 psis, the gos will expand appraximately $9500 / 93005$, or about $2 \%$. This small portion of the gas in rear welloore pore space that is at critical gas soturation will become motile and will be produced.

The amount of gas will be small. But recall from Section 23 that the composition of the gas will be markedly different fram the composition of the dissolved gos that is normally produced. While small gis composition changes aver long periads of time may be attrituted to many foctors, these same small changes over a period of a few hours needed to perform a butble test are conclusive. If the ethane/methane and propane/methane ratios incresse after "bottoms-up" during a butble test, free gas is being produced.

\subsubsection{Febuary 11,1986 Bubble Test}

On Fetuary 11, 1966 the brine rate was incressed from stout $23000 \mathrm{~B} / 0$ to about 28500 B/D. IGT collected gos samples and anolysed them on-site Exhibit 2.6 presents the relevant data. As the brine rate increased the calculated bot tomhole pressure dropped from 9560 to 9250 fos. The 


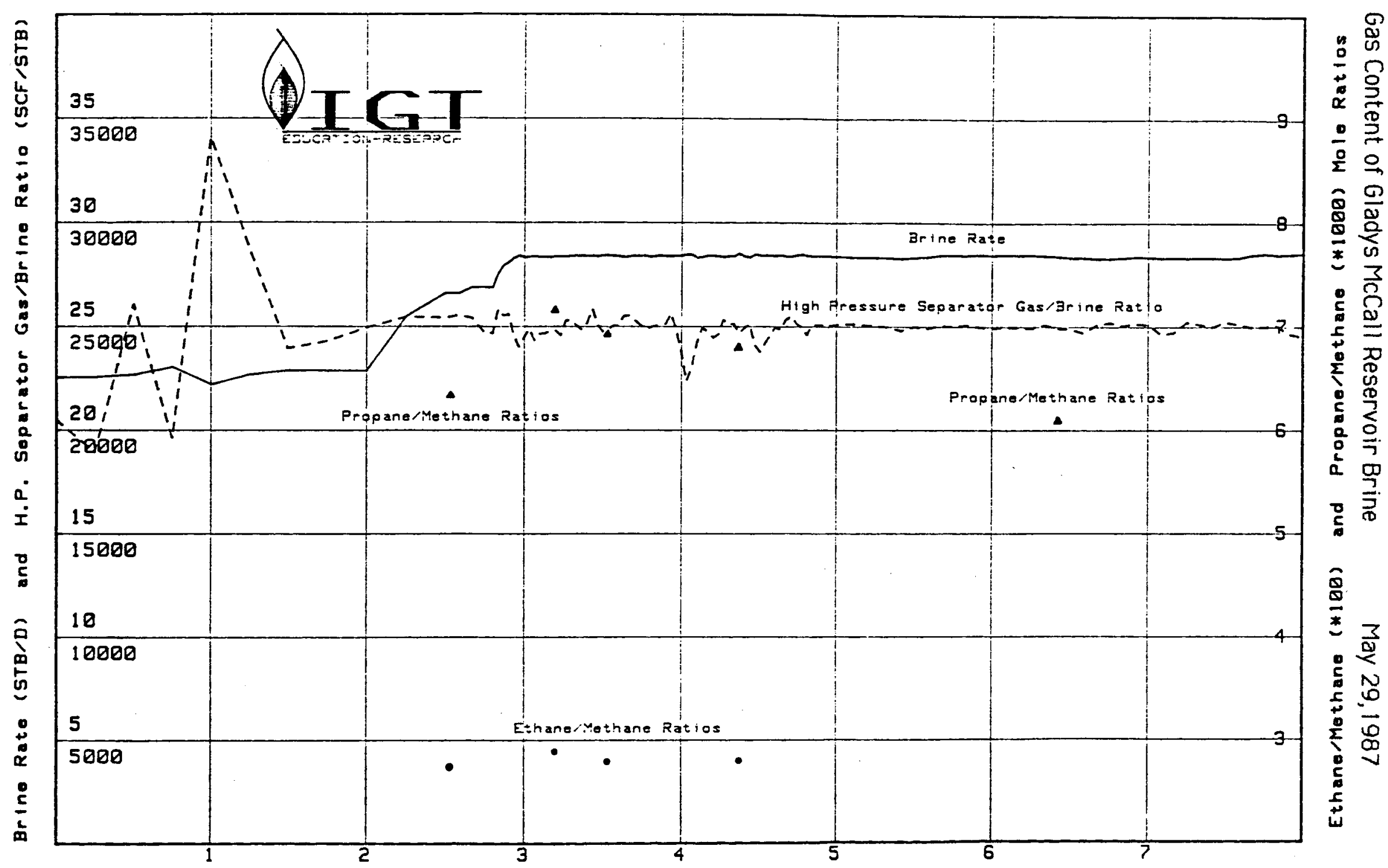

Gladys McCall Bubble Test - Hours After 08:00 on 11 FEB 1986

Exhibit 2.6 Brine Rate, First Stage Separator Gas/Brine Ratio, and Hydrocarbon Ratios vs. Time on Febuary 11, 1986 
rotios of ethane/methane and propane/methane changed significantly, as tatulated in Exhibit 2.7 and shown graphically in Exhitit 2.6.

Exhibit 2.7, Total Gos Hydrocartion Ratio Changes

During The Febuary 11, 1986 Eutible Test

Time in Test

Ethore/Methane

Propone/Methane

Eefore rate increase

0.0257

00056

After rate increase, tiefore

"trottoms-up"

0.0259

0.0056

Atrout 15 minutes after bottoms-up

0.0271

00063

Atrout 30 minutes after bottoms-up

0.0263

00061

About 60 minutes after bottam-up

0.0265

00060

Atrout 3.5 hours af ter bot toms-up

00257

0.0055

About 8 days after bottoms-up

0.0259

00054

The increase in the hydrucartion ratios after the slow cotrout ane hour) increase in brine rate was abyious in the above table and in Exhibit 2.7 Eut, examination of Exhibit 2.6 reveals no otwous increase in the gos to brine ratio. The increase, if any, was less than 1SCF/STE. The gas composition dota (Exhibit 2.7) reveals that the maximum amount of time that free gas may have been produced was 4 hours. This leads us to conclude that free gas production was less than 5 MLF

At bottomhole pressure and temperature 5MCF of gas would accupy less than 12 cubic feet of pore volume. Adjusting for porosity $(16 \%)$ and the gssumed water saturgtion (97\%), this is equivalent to the gas content of 2500 cubic feet of reservoir rack. As the fraction of gas produced would te proportional to the drop in the bottamhole pressure, which declined from 9580 psia to 9250 psia (only $36 \%$ of the free gas could flow), the free gos phose at the critical gos saturation necessary to produce $5 \mathrm{MCF}$ of gos should occupy 70,000 cutic feet of reservair rock. Assuming a pay thickness of 300 feet this volume would be a cylinder with a radius of 8.6 feet. This is an upper limit because on upper limit for free gas production (1 SCF/STE for 4 hours) was used in these calculations 
The buildup of free gos to critical gas soturation would have to have accurred over a time of doys or weeks before the "bubble test". Review of the histary of calculated flowing bottomhole pressure suggests that this may have occurred during the fourth quarter of 1965 at a pressure of roughly $9500 \mathrm{psi}$.

\subsubsection{April 14, 1987 Bubble Test}

During April 1987 the bubble test was repeated. Long term production had reduced the bottamhole pressure to about 8600 psia. Flawrotes had teen cantralled by the first stage separator pressure, and the chokes were fully open. It was recogrised that increasing the flawrate required lawering the separator pressure. If this accurred during the bubble test, changing inventories of gas in the separator yolume would make it difficult to quantize sny change in the gos to brine ratio.

on April 13, 1967 the first stage separotor pressure was lowered from 1010 psia to 515 psia, a minimum pressure needed to maintain contral of the levels in the separators and drive the disposal well. At the same time, the chakes were adjusted so that the wellhead pressure remained constant ot about 1150 psia and brine rate remained constant at slightiy shave $22,000 \mathrm{STB} / \mathrm{D}$. The well was then allowed to run overnight so that the gas compasitions in the separators would equilibrste at the lower separstor pressure and good baseline data could be obtained.

The chokes were then opened all the way at 1200 hours on April 14. The trine rate jumped from 22050 to $25300 \mathrm{STB} / \mathrm{D}$, the wellhead pressure drapped from 1150 to $710 \mathrm{psia}$, and the calculated battamhole pressure dropped from 8590 to 8395 psia. Exhitit 2.6 presents the changes in the gas to trine ratio, the brine flow rate, and the hydrocartion ratios during the test. Changes in hydrocarban ratios are also tabulated in Exhibit 2.9.

While the changes in the hydrocarban ratios ore not ss clear during this test as in the Febuary 1986 test, an increase in the hydrocartion ratios is evident. In Exhibit 2.6 it is also clear that the production of free gos was at most trivial. The bubble, if it could be called such, consisted of less then 1 MCF of gas. 


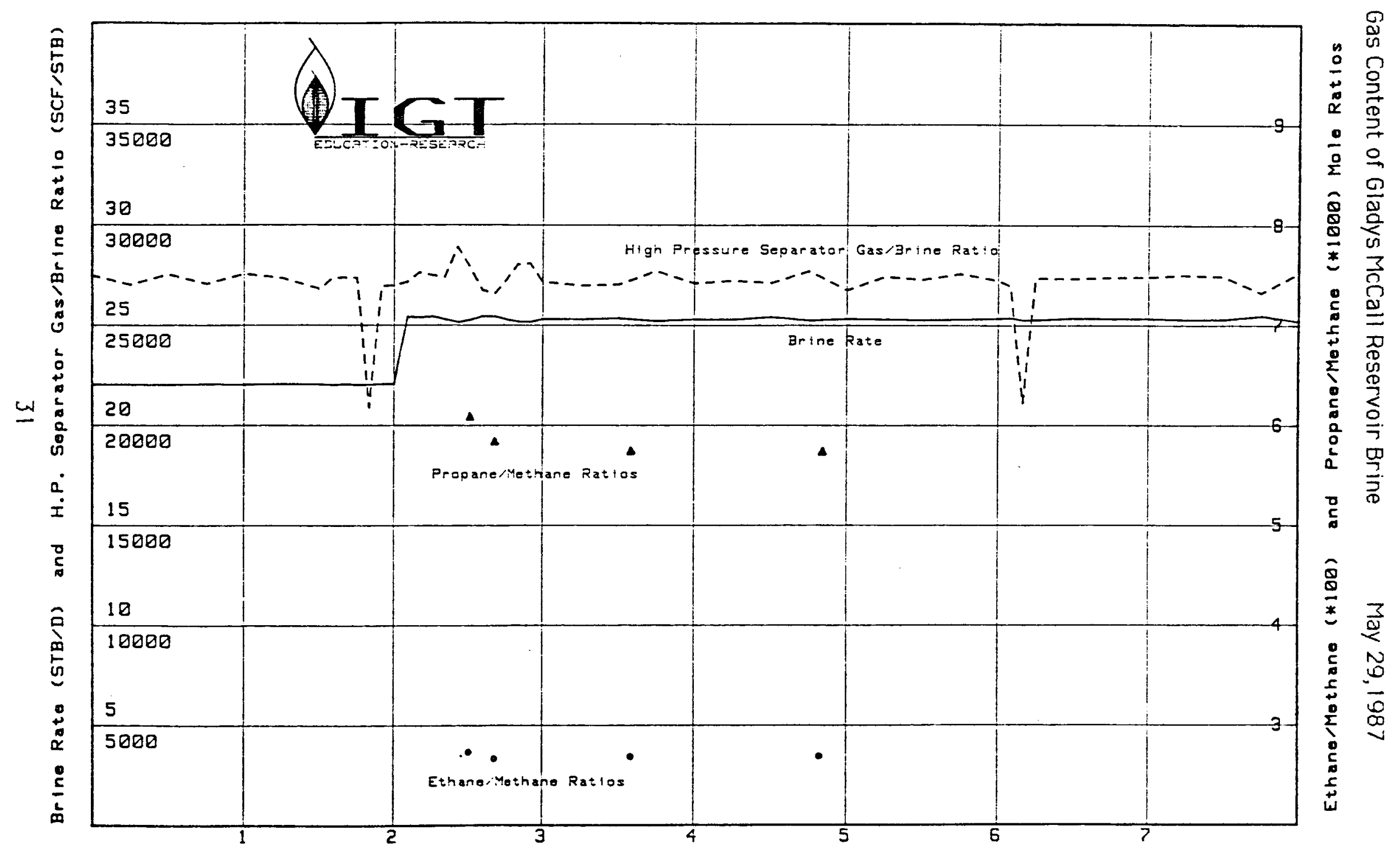

Gladys McCall Bubble Test - Hours Aftor 10:00 on 14 APR 1987

Exhibit 2.8 Brine Rate, First Stage Separator Gas/Brine Ratio, and Hydrocarbon Ratios vs. Time on April 14, 1987 
Exhitit 2.9, First Stgge Separator Gas Hydrocorton Rotio Changes During the Apri\} 14, 1967 Butble Test

Time in Test

Eefore rate increase

About 15 minutes after tottame-up

Atrout 25 minutes after bottoms-up

About 60 minutes after bottoms-up

Atout 25 hours after bottoms-up

About 10 hours after bottoms-up

About 18 hours after tottoms-up
Ethane/Methene

$$
\begin{aligned}
& 00264 \\
& 00274 \\
& 00266 \\
& 00269 \\
& 00269 \\
& 00265 \\
& 00267
\end{aligned}
$$

Froporemethone
00055
0006
00058
00057
0.0057
00050
0005

This is only stout 25 cubio feet of gos at bottomole pressure and tempersture Adjusting for porosity (16\%) and the assumed water soturation (97\%) this is equivalent to the gas content of 500 cutic feet of reservit. The froction of free gos that would te produced se proportionat to the drop in the bot tamble pressure and the resultont gos exponsion (atout $195 \mathrm{psi} / 6395 \mathrm{peia}$, or $23 \%$. Thus one MCF of gos le estimated ta have come from a reservoir volume af about 20 poo cubic feet. Assuming g thicknes of 300 feet, the qulume would be in s cylinder with a radius of 4.46 feet.

This date is not inconsistent with the Febuary 1960 test, which concluded that any free gos froduction had to come from a gyinder with a radius LESS than 7.7 feet.

\subsubsection{Discussion of Bubble Test Results}

The minmal "butble" an April 14, 1967 was g dissopoointing surptise to thase of us who had observed and sampled butbles during the tests of Wells of apportunity. However, some algetrs has revesled that the properties of the Gladys McCall reservair are such that a dramatio: "butuble" should not be expected.

The mothematical model that provides insight consists of examining is right circular cylinder in the reservoir that is concentric with the 
wellbore and has a radial thickness $\Delta r$. Brine that is below its bubble point pressure and is radially flowing through this cylinder of reservoir rock liberates about 0.002 SCF/STB of gas per psi of pressure drop across the radial thickness $\Delta r$. But, that flowing pressure drop is related to the dimensions of the cylinder and brine rate by Darcies Law. Equating the pressure drops from the equations for these two phenomena makes possible solving for the time required to achieve critical gas saturation as a function of radial distance from the wellbore, brine rate, and reservoir parameters. In conventional oil field units, the resultant equation is:
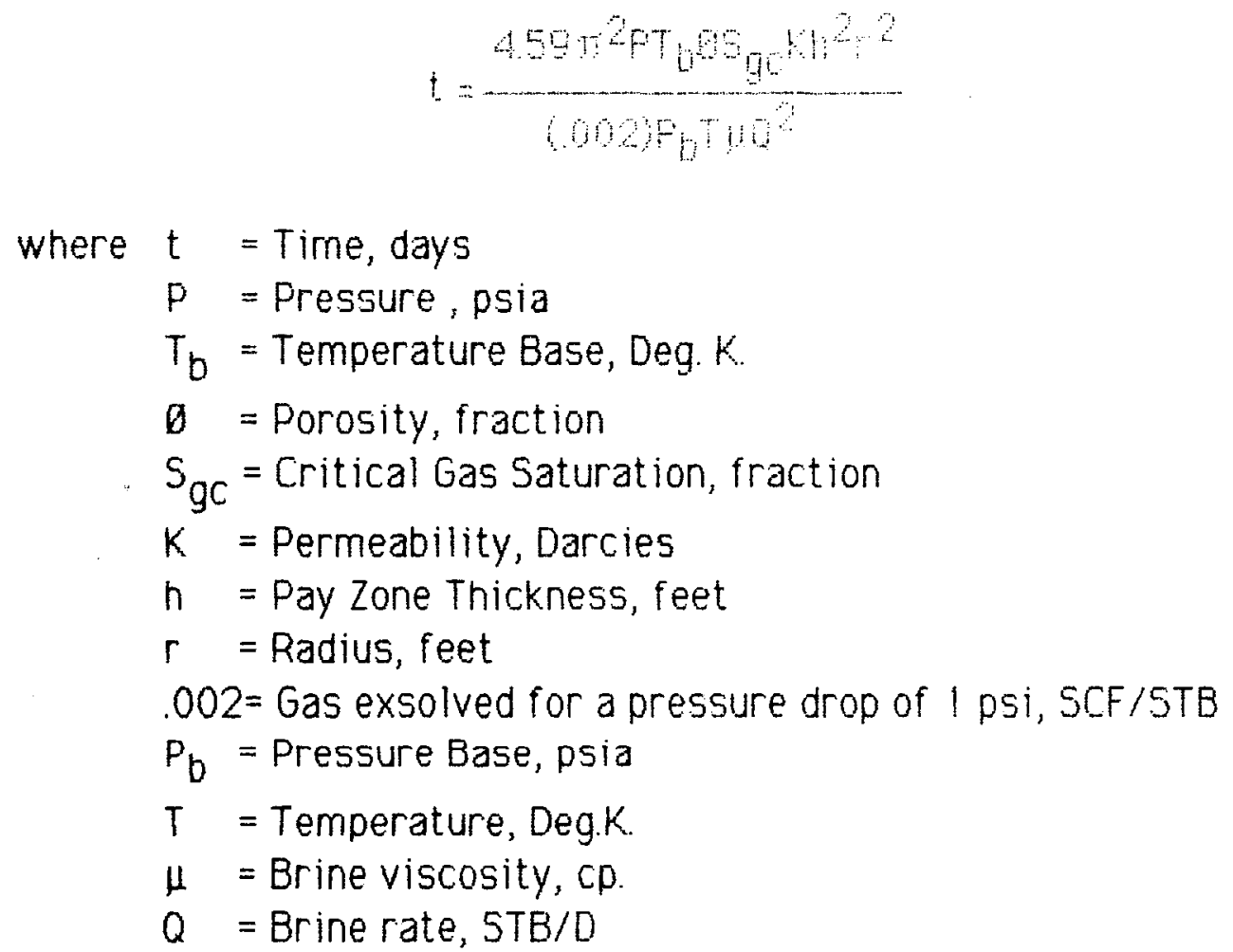

Solving this equation for the Gladys McCall well for a flow rate of 25,000 STB/D and for a radius of 10 feet reveals that about 320 days or more than 10 months would be required to achieve critical gas saturation. In contrast, for the Wells of Opportunity where the bubbles were observed, permeability and thickness were both about an order of magnitude smaller than for the Gladys McCall well. For a brine rate of 5000 STB/D, such well would achieve critical gas saturation 10 feet from the wellbore in the much shorter time of about a week. 
This very slow buildup of the critical gas saturation in the reservoir, coupled with not being able to change the bottomhole pressure more than a few percent, lead us to conclude that there is no reasonable engineering basis to support expectations of a large bubble of free gas being produced during April 1987. The bubble test was successful in that it did provide a qualitative indication that the bottomhole pressure was below the bubblepoint pressure of the reservoir brine.

\subsection{CONCLUSIONS FOR THE GLADYS MCCALL WELL}

The Gladys McCall Sand \# 8 was not saturated with gas at the origional reservoir pressure of 12783 psia. The bubble point pressure for the reservoir brine was probably between 9400 psia and 10000 psia. The tests and interpretations thereof used to reach this conclusion are summarized below.

- The $1983 \mathrm{P}-\mathrm{V}-\mathrm{T}$ analyses found a recombination bubble point pressure of 9200 psia for a gas to brine ratio of 30.25 SCF/STB. This result closely matched the methane solubility predicted by Blount's equation. The methane solubility predicted by Blount's equation, at $294 \mathrm{~F}$ and $95000 \mathrm{ppm} \mathrm{NaCl}$, is $30.30 \mathrm{SCF} / \mathrm{STB}$ at 9200 psia and 35.85 SCF/STB at 12783 psia.

- The produced gas to brine ratio appeared to start a very slow decline in the latter half of 1985. Bottomhole pressure had never been below 10,500 psia prior to the successful inhibitor pill in June 1985. After that pill, the vast majority of production has been at rates high enough for flowing bottomhole pressure to be below 10,000 psi and it got as low as 9400 psi during the latter half of 1985. The decline in the produced gas to brine ratio is assumed to be caused by gas being liberated in the reservoir due to the bottomhole pressure falling below the bubblepoint pressure.

- Changes in the produced brine composition (the barium concentration in the brine jumped over $400 \%$ between February and May 1985) and the characteristics of the produced hydrocarbons (oil production was first noticed during January 1985) may indicate 
arrival at the wellbore of brine from a a different reserboir comprartment having a different gos content. But, if so. This brine is also undersaturated with natural $90 \mathrm{~s}$ and therefore the major conclusian remains unchanged.

- The produced gas compasitian changed slightly between April and oecember 1965 There were no gas analyses during this period. The chenge, a slight reduction in the ethane/methane and fropane/methone ratias, is consistant with gas being liberated from the birine in the resoryar. The calculated tottombele pressure ranged from 9400 psia and 10800 psia and the mojority of production was with bottomhale pressure below 10,000 psi Agin. there remoins a possibility that a previausly isolated brine started teing produced during this time frome as discussed above.

- The February 11, 1986 bubble test provided conclusive enidence that the bottamhole pressure had been belaw the bubble point prior to that time. The lowest bottamhole pressure experienced before the test was 9400 psia in actober 1985 . Therefore the butile proint pressure of ariginal reservoir brine must have been above 9400 psio.

- The April 14, 1987 bubble test indicoted that the butble point pressure was atove 8600 psia. The result was redundant after the 1966 test but the small size of the 1987 bubble test motivated analysis that provided additional insight into the design and interpretation of future bubble tests.

\subsection{OTHER DESIGN WELLS AMD RECOMMENDATIONS}

The Gladys McCall reservoir brine was originally undersaturated with natural gas and bottomhole pressure hos teen drown to below the butite point pressure. We know af no additional tests. that do not require continuing production for years, that could improve definition of the ariginal butble point pressure for this reservair. While evidence supporting the undersoturated canclusion is strang, the minimal quantity and questionable quality of much of the data make interpretation and reporting both difficult and tedious. 
One can readily conclude from putilished dat a that none of the design wells have produced brine that was soturated at ariginal reservoir temperature and pressure. There is a P-Y-T report for every tested sand in every design well that shows a butble froint thousands of psi below origina! reservoir pressure. The following statement by OOE's prime controctor for the Sweet Lake and Gladys McCall wells is in the CK GeoEnergy Curporation minutes of the januory 10, 1904 DOE/INDUSTR GEOFRESGURE GEOTHEFMAL RESOURCE DEYELOPMENT PROGRAM WORKING GROUP MEETING:

"Now this is the fourth reservoir limit test that we'we done two st Sweet Lake and two ot Gladys McCall. All af them show roughly the same thing. They are atout $80 \%$ saturated. Never mind the brine is different, never mind the gas ta water ratios are different. They calculate out to be about bos saturated."

We have not found reports wherein DOE's prime contractors far the other two design wells have explicitly reported on whether the reservoir trine was saturated with natural gas. But, detailed examination of the data by IGT has failed to make a plausible case for either of them being saturated. In the cose of the DOW-DOE L.R. Sweezy No.1 well, probiems in messuring gas production were so great that little data was reported and the errors therein may well be $30 \%$ or more.

For the Pleasant Bayou No. 2 well, production of 4.5 millian barrels of brine was accompanied by little, if any, change in reported gas/brine ratia. For the last 30 million barrels, brine rate averaged a reported 16,375 STB/D. Under these canditions, sppreciable drswdown must have occurred. With the exception of cryacondensates and scale related anslyses, it appears thot no fluid analyses were performed during the lost 3 milion barrels. Nevertheless, the lack of decline in reported gasitine ratio out of the separators makes it unlikely that the reservoir brine was satursted with notural gas at ariginal pressure.

It is recommended that future design well tests involve much heavier emphasis upan definitive determination ss to whether reservoir brine is saturated with natural gas. Recommendations to achieve this include: 
- Accurate gas rate measurement, including sufficient gas analyses to be confident that correct values are being used for gas composition dependent factars in the orifice equation. Correction of rates for water vopar and corbon diaxide content of the gos poseing through the meters is essential.

- P-V-T studies performed in laboratories copable of pressures it. least as high as original reservoir pressure. Recombinotians should be performed at gas to brine ratios higher than the "produced" gos to brine ratio if higher retios are needed to reach the original reservoir pressure.

- Hydracartion and brine sample collection and analysis in a standard manner after every month or after every millian tiarrels of production, whichever is more frequent, as well as in conjunction with changes in production rate. Total produced gos, including gos remaining in solution in brine and cartion diaxide liberated from brine by acid at atmospheric pressure, needs to be determined each time.

- Bubble tests should be perfarmed at those times when prior understanding mokes it credible that production has reduced near wellbore pressure to below the bubble point pressure. Note that the bubble test will be much more definative of the bubble point pressure on the Pleasant Bigyou well than on the Giadye tocall well. This is because the reseryoir thickness is only $1 / 5$ th as large and the time to charge pores to critical gas saturstion yares as the square of thickness. 


\section{APPENDIX A}

Weatherly Laboratories, Inc.

\section{Reservoir Fluid Analysis}

Gladys McCall Well No. 1, Sand No. 8 
RESERVIR FUUID AMALYSIS

Far $\%$

TECAMARIL-FEMIX \& SCISSON, IMC.

CLADYS MOCALL WEL NO. 1, SAND 8

EAST CRAB LAKE FIEDD

CAMERON PARIEH, LOUISIANA

$\%$

7

$\%$

$\%$

$\%$

$\%$

$\%$

$\%$

8

$\%$

$\%$

$\%$

$\%$

$\%$

$\%$

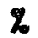

8 


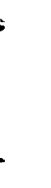


MEATHERYY LABDSATORIES, INC.

J. E. WEATHERLY, NR.

223 GEORBETTE LAFAYETTE, LA 70506

JOAN D. NEAL CHAIRTAN PHONE (318) 232-4877

PRESIDENT

BRYAN SONWIER

VICE PRESIDENT

\title{
OCTOBER 24, 1983
}

TECHAADRIL-FENIX \& SCISSON, INC.

3 MORTHPOINT LRIVE

SUITE 200

HOUSTON, TEXAS 77060

ATTENTION: MR. LARRY DURRETT

\author{
RE: RESERVOIR FLUID STUDY \\ GLADYS MCCALL WELL NO. 1, SAND 8 \\ EAST CRAB LAKE FIELD \\ CAMERON PARISH, LOUISIANA
}

\section{GENTLEREN:}

ATTACHED ARE THE RESULTS OF THE ANALYSES OF THE CHEMICAL AND PHYSICAL CHARACTERISTICS OF A RECOMBINED RESERVOIR FLUID SAMPLE FROM THE SUBUECT WELL. SLRFACE SEPARATOR SAMPLES WERE COLLECTED FROM THIS WELL BY A REPRESENTATIVE OF WEATHERLY LABORATORIES, INC. ON OCTOBER 8, 1983. THE GAS-WATER RATIO (GWR) MEASURED ON THIS TEST, 25.01 CUBIC FEET OF SEPARATOR GAS PER BARFEL OF SEPARATOR LIQUID, WAS USED AS THE BASIS FOR ONE RECOMBINATION. THE RESULTANT RESERVOIR FLUID EXHIBITED A BUBBLE POINT OF 9,200 PSIA AT THE RESERVOIR TEMPERATURE 290 DEGREES FAHFENHEIT.

OTHER RECOMBINATIONS WERE DONE TO DETERMINE A BUBBLE POINT -VS- GR RELATIONSHIP. A DIFFERENTIAL LIBERATION AND VISCOSITY MEASUREMENTS WERE PERFORTKD USING RESERVIR FLUID RECOMBINED TO THE PRODUCED GWR AT THE TIME OF SAMPLING.

WE WISH TO THANK YOU FOR THIS OPPORTUNITY OF SERVING YOU. SHOULD THERE BE ANY QUESTIONS CONCERNINO THIS REPORT, PLEASE CONTACT US.

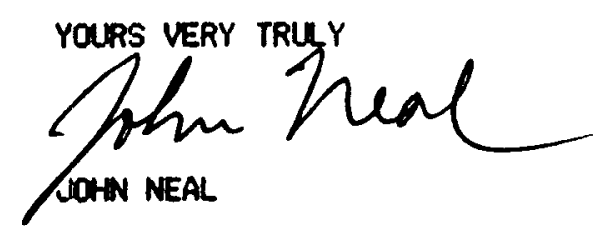

CC: MR. NONE BERNING

TECHNALRIL-FENIX \& SCISSCN, INC.

RT. 1, BOX 36-B

CRAND CHENIER, LA 70643

LAB. NO. N2106-10457 
TECHNADRIL-FENIX \& SCISSCN, INC. GLADYS MCCALL WELL ND. 1, SAND 8 EAST CRAB LAKE FIELD

CEOPRESSURE/CEOTHERWAL PROUECT SANFING AND LABORATORY PROCEDURE

1) WATER VAPOR CONTENT OF SEPARATOR GAS HAS DETERMINED BY FLOWING GAS FROM A METERING VALVE ON THE SEPARATOR GAS METER RUN THROUGH A WEIOHING TUBE (INDICATCIR DRIERITE (CaSO4) LEIGHED TO 0.1 MILLIGRAM) TO A RUSKA GASOMETER. SEPARATOR GAS SAMPLES WERE TAKEN FROM THE SAME PLACE INTO I GALLON STAIMESS STEEL (S.S.) CYLINDERS AFTER THOROLGH PURGING. SEPARATOR LIQUID SAMPLE CYLINDERS (1000 M. S.S.) WERE FIRST CHARGED WITH SEPARATOR GAS TO FUUL SEPARATOR PRESSURE. THE LIOUID CYLINDERS WERE THEN CONNECTEU TO THE SEPARATOR WATER SAMPLINO POINT BY A S.S. TUBE LONG ENOUGH TO LOOP THROUGH A COOLING BATH. THE WATER TRANSFER LINE WAS THEN SLONLY AND THOROUGHLY PURGED AT THE CYLINDER. SEPARATCR WATER WAS LET INTO THE CYLINOER BY SLOWY BLEEDING GAS FROM THE TOP VALVE. AT NO TIME WAS THE WATER CAUOHT IN THE CYL INDER ALLOWED TO DROP BELOW SEPARATOR PRESSURE.

2) FLASH LIBERATION OF GAS FROM SEPARATCR WATER HAS ACCOMPLISHED BY USING A WEIGHEI SEPARATOR FLASK. THIS SEPARATOR FLASK WAS CONECTED TO THE OUTLET OF A SEPARATOR WATER CYLINDER BY A SHORT CAPILLARY LINE. GAS FROM THE SEPARATOR FLASK PASSED THROUCH A HEIGHED DRYINO TUBE THROUGH A GLASS CYLINDER ( 300 ML.) TO A RUSKA GASOMETER. A VACUUM VALVE AND A MERCURY MANOMETER WAS CONNECTED TO THE GAS MANIFOLD BETHEEN THE DRYINUS TUBE AND THE GASONETER. BEFORE COMMENCING THE FLASH, THE ENTIRE FLASH GAS MANIFOLD WAS EVACLATED AND THEN FILLED WITH HELIUM TO ATMOSPHERIC PRESSURE. A KNOWN VOLUNE OF SEPARATOR WATER HAS PUSHED OUT OF THE SAMPLE CYLINDER AT A PRESSURE SLIGHTLY ABONE FIELD SEPARATOR PRESSURE BY USE OF A CALIBRATED MERCURY PUMP. THE VOUUYE OF STOCK. TANK WATER PRODUCED WAS DETERMINED BY ITS WEIGHT AND DENSITY. THE VOLUME OF DRY GAS EVOLVED WAS DETERMINED HITH THE GASOMETER. THIS CAS VOLUME WAS SUBJECT TO $+2 \%$ ERROR DUE TO THE VERY SMALL AMOUNTS MEASURED. THE GAS WAS CHARGED TO A CHROMOTOGRAPH FOR ANALYSIS FROM THE GLASS CYLINDER.

3) PHYSICAL RECOMBINATION OF SEPARATOR EFFLUENTS:

SEPARATCR GAS WAS CHARGED INTO A TEMPERATURE CONTROLLED CELL. THE VOLUME OF THIS WINDOWED CELL IS KNOWN FOR ANY PRESSURE AND TEMPERATURE. THE PRESSURE OF THE GAS IN THE CELL WAS MEASURED WITH A MERCURY MANOMETER AND A BAROMETER. THIS CALCULATELI GAS VOLUME WAS SUBJECT TO A $+1 \%$. ERROR DUE TO THE STALL AMOUNT CHARGED TO THE CELL. A VOLUME OF SEFARATOR WATER WAS CHARGED INTO THE WINDOUED CELL BY USE OF A CALIBFATED MERCURY PUMP. THE WATER LAS METERED AND MEASLRED AT A PRESSLRE SLIGHTLY ABOVE FIELD SEPARATOR PRESSURE. FOUR RECOHBINATIONS WERE DONE IN ORDER TO PRODUCE A SATURATION PRESSURE-US-GAS WATER RATIO CURVE. RESERWOIR FLUID RESULTING FROM RECUMBINATION OF THE PRODUCED GWR (FIFTH RECOMBINATION) WAS USED TO PERFORM A DIFFERENTIAL LIBERATION AND VISCOSITY MEASUREMENT. 
TECHNADRIL-FENIX \& SCISSON, INC. QRADYS MCCALL WELL NO. 1, SAND 8 EAST CRAB LAKE FIELD

4) PRESSURE-VOLUME RELATIONS OF RECOMBINED RESERVOIR FLUID AT RESERVOIR TEMPERATURE: EACH DATUM OF PRESSLLE-VOLLHE RELATIONS WAS CORRECTED FOR MERCLRY PUMP CALIBRATION, MANIFOLD EXPANSION, CELL EXPANSION, MERCURY COMPRESSIBILITY AND MERCURY THERMAL EXPANSION. LIQUID VOLUHE PERCENT HAS IETERMINED BY CALIBRATED CATHETONETER AND BY DATA INTERPRETATION.

5) DIFFERENTIAL LIBERATION OF RESERVOIR FLUID AT RESERVOIR TEMPERATURE:

GAS FROM EACH PRESSURE DECREMENT OF THE DIFFERENTIAL LIBERATION HAS ANALYZED IN THE SAME MANER AS DESCRIBED IN 2), (FLASH LIBERATION). DIFFERENTIAL LIQUID CHANGES WERE NOTED.

6) VISCOSITY OF RESERVOIR FLUID WAS MEASURED BY MR. J. R. COMEAU OF WEATHERLY LABORATCRIES. A DESCRIPTION OF MR. CONEAN'S EXPERIMENTAL PROCEDURES IS GIVEN BELOW: CEOTHERTAL WATER VISCOSITIES WERE REASURED USING A RUSKA ROLLING BALL VISCONETER WITH AN ELECTRONIC DETECTION SYSTEM TO PREVENT ELECTROLYSIS. THE DETECTION SYSTEM CONSISTS OF A SENSITIVE AUDIO AMPLIFIER WITH POSITIVE FEEDBACK ADUUSTED UST BELOW OSCILLATION. THE BALL IS HED BY AN ELECTROMAGNET. HHEN CURRENT TO THE MAGNET IS TURNED OFF, A PULSE IS PRODUCTED WHICH STARTS A DIGITAL TIMER. WHEN THE BALL STRIKES THE CONTACT AT THE OTHER END OF THE VISCOMETER THE ELECTRICAL DISTURBANCE PRODUCED IS GENERALY AMPLIFIED AND TURNS THE TIMER OFF. TIMES WERE MEASURED TO $1 / 100 T H$ OF A SECOND AND AVERACED. THE VISCOMETER WAS CALIBRATED AT EACH OF THO ANOLES USING DISTILLED WATER AT SEVERAL TEMPERATURES. THESE RESULTS WERE USED ALONO WITH PREVIOUS RESULTS TO OBTAIN NEW CALIBRATION CURVES. $t$ P VERSUS U WERE PLOTTED TO OBTAIN CALIBRATION.

$t=$ ROLL TIME, (SECONDS)

$p=$ DENSITY DIFFERENCE BETHEEN BALL AND RESERNOIR FLUID, $(\mathrm{gm} . / \mathrm{m})$.

$u=$ VISCOSITY, (CENTIPOISE)

THE VISCOMETER WAS CHARGED HITH RESERVOIR FLUID ANU RUN AT 290 'F AT 1000 LB. INTERVALS. THE VISCOSITIES HAD A PROBABLE ERROR OF \pm 0.01 CENTIPOISE.

NOTE! ALL DATA FOR PRESSURES GREATER THAN 11, PSI WERE OBTAINED BY EXTRAPOLATION, THE VISCOSITY DATA ARE ABOUT 0.1 CENTIPOISE LOWER THAN THE PREVIOUS REPORT (N190110224 OF APRIL 1983). HE BELIEVE THAT THIS IS DUE TO A FILM BUILDUP IN THE 404 S.S. BARREL OF THE OLD E.L.1. VISCOHETER. THIS FILM DID NOT FORM IN THE 316 S.S. BARREL OF THE RUSKA VISCOMETER. 
FIELD DATA FOR WEATHERLY LABORATORY INUESTIGATION

WEH RECORD

COMPANY

WELL

FIELD

PARISH AND STATE
TECHMADRIL-FENIX \& SCISSON, INC.

GLADYS MCCALL MO. 1

EAST CRAB LAKE

CAMERON, LOUISIANA

FIED CHARACTERISTICS

FORMATION NAME

SAND NAME AND DESIGNATION

8

DATE COMPLETED

ORIGINAL RESERVOIR PRESSURE

WEL CHARACTERISTICS

ORIGINAL PRODLCED GAS-LIQUID RATIO

PERFORATIONS

ELEVATIONS

TOTAL DEPTH

LAST RESERWOIR PRESSURE

RESERVIR TEMPERATURE

12,783 PSIA

290 DEGREES $F$

SAMPLINO CONDITIONS

DATE SAMPLED

TUBING PRESSURE, FLOWING

PRIMARY SEPARATCR TEMPERATURE

(METER RUN)

PRIMARY SEPARATOR PRESSURE

PRIMARY SEPARATOR GAS RATE

SEPARATOR LIQUID RATE

(NET GAS)

GAS-LIQUID RATIO (SEPARATOR)

$10-8-83$

$12-8-83$
12,676

97

500

349,750

13,987

25.01

PSIO

DEGREES F, (SEP.) $26 \cdot 8^{\prime} \mathrm{F}$

PSIG

SCF/DAY

BBLS. /DAY

SCF / BEL. SEP. WATER

SHRIMKAGE FACTOR (VO.S.T.WATER $\odot 60^{\prime}$ F/VO. SEP. WATER)

0.9437

BAS-LIQUID RATIO (STOCK TANK)

26.50 SCF/BEL.S.T. WATER

PRESSURE BASE

15.025 PSIA 60 DEGREES $F$

NOTE: FOR DRY GAS, 24.95 SCF/BBL. SEP. WATER SEP. CONDITIONS.

26.44 SCF/BEL. S.T. HATER $60^{\prime} \mathrm{F}$. 
TECHNADRIL-FENIX \& SCISSON, INC.

GLADYS MCCALL WELL NO. 1, SAND 8

EAST CRAB LAKE FIELD

CALCULATION OF GAS RATE, 10-8-83 TEST

(Factors from OPSA Engineering Data Book)

\begin{tabular}{|c|c|c|c|c|c|c|c|c|c|c|}
\hline V/the Pf & $=$ & 107.5735 & $H$ & $=$ & 22.47 & $" \mathrm{H} 2 \mathrm{O}$ & , & $\mathrm{Pf}$ & $=$ & 515 psia \\
\hline $\mathrm{Fb}$ & $=$ & 113.9873 & D & $=$ & 2.6 .26 & " & , & $d$ & $=$ & $0.750 "$ \\
\hline$F p b$ & $=$ & 0.9804 & & & 15.025 & psia & & & & \\
\hline Fr & $=$ & 1.0004 & $b$ & $=$ & 0.0470 & & & & & \\
\hline$Y 2$ & $=$ & 1.0003 & $\mathrm{H}$ wa $/ \mathrm{Pf}$ & $=$ & 0.042 & & ' & $d / D$ & $=$ & 0.286 \\
\hline $\mathrm{Fg}$ & $=$ & 1.2116 & Gravity & $\mathrm{s}$ & 0.6812 & & ' & $\mathrm{Fg}$ & $=$ & $1 / 1 / 0.6812$ \\
\hline Ftf & $=$ & 0.9662 & Temp. & $:=$ & 97 degre & $\operatorname{ses} F$ & ' & Ftf & $=$ & $1 / 520 / 557$ \\
\hline \multirow[t]{3}{*}{ Fpv } & $=$ & 1.0348 & pTr' & $=$ & 1.547 & & ' & $\mathrm{pPr}^{\prime}$ & $=$ & 0.751 \\
\hline & & & $z$ & $=$ & 0.9339 & & 1 & Fpv & $=$ & $1 / \overline{1}$ \\
\hline & & & Epsilan & $=$ & 12.5 & & & & & \\
\hline
\end{tabular}

$Q=\sqrt{ }=\overline{H W f} \times F b \times F p b \times F r \times Y 2 \times F g \times F t f \times F p v \times 24$

$Q=349,750$ SCF/day 215.025 PSIA 60 Degrees $F$ (WET) 
TECHNADRIL-FENIX \& SCISSON, INC. GLADYS MCCALL WELL NO. 1, SAND 8 EAST CRAB LAKE FIELD

\section{RESERVIR FLUID SUMARY}

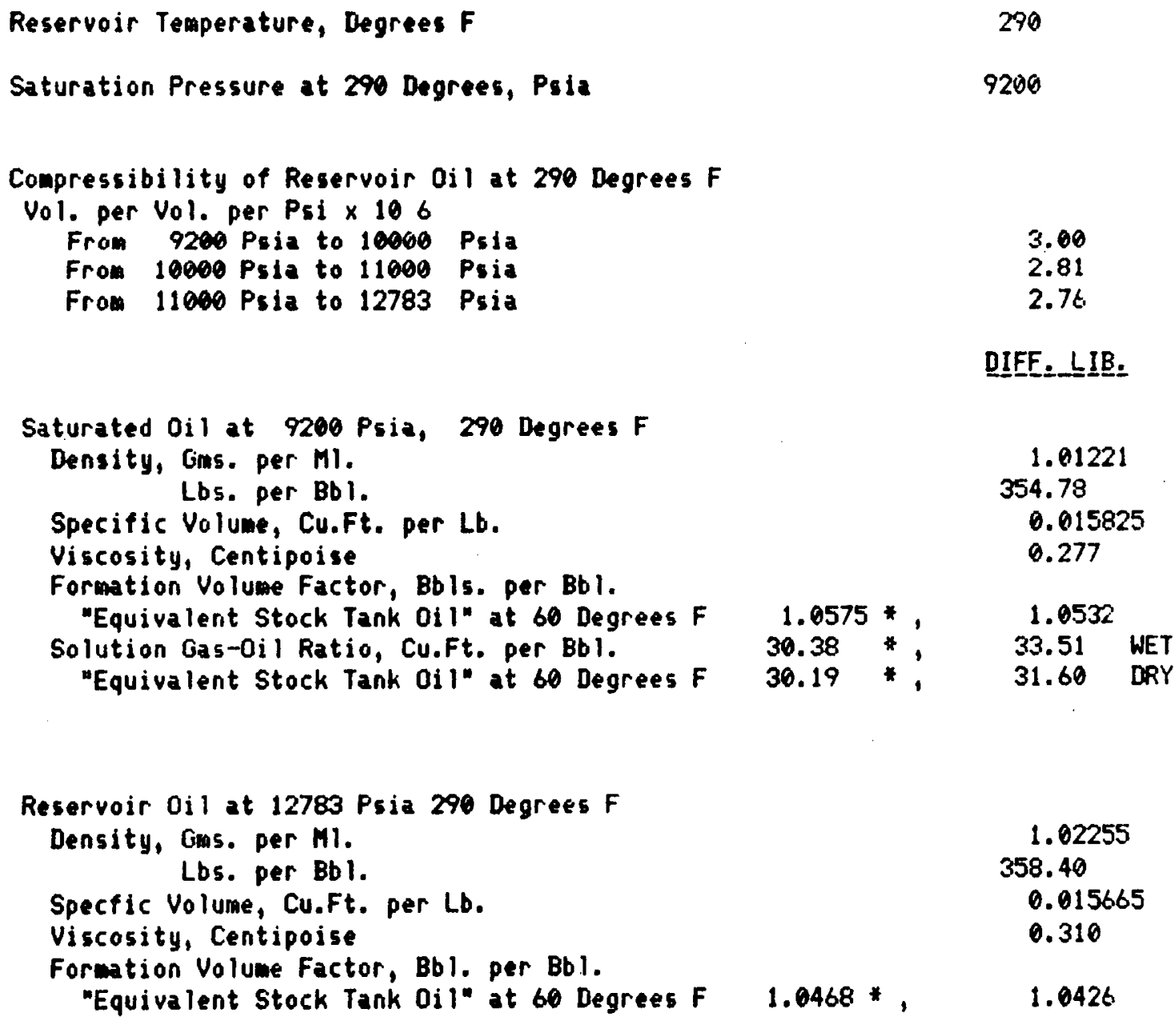

NOTE: REFERENCES TO 'OIL' ABOVE SHOULD READ 'WATER'.

* based on separator hater flash. 
TECHNADRIL-FENIX \& SCISSON, INC. GLADYS MCCALL WELL NO. 1, SAND 8 EAST CRAB LAKE FIELD

COMPOSITE LABORATORY DATA 29 DECREES F

RECOMBINATION (1) 20.00 SCF SEP. GAS 15.025 PSIA \& 60'F/BEL. SEP. WATER O SEP. CONDITIONS.

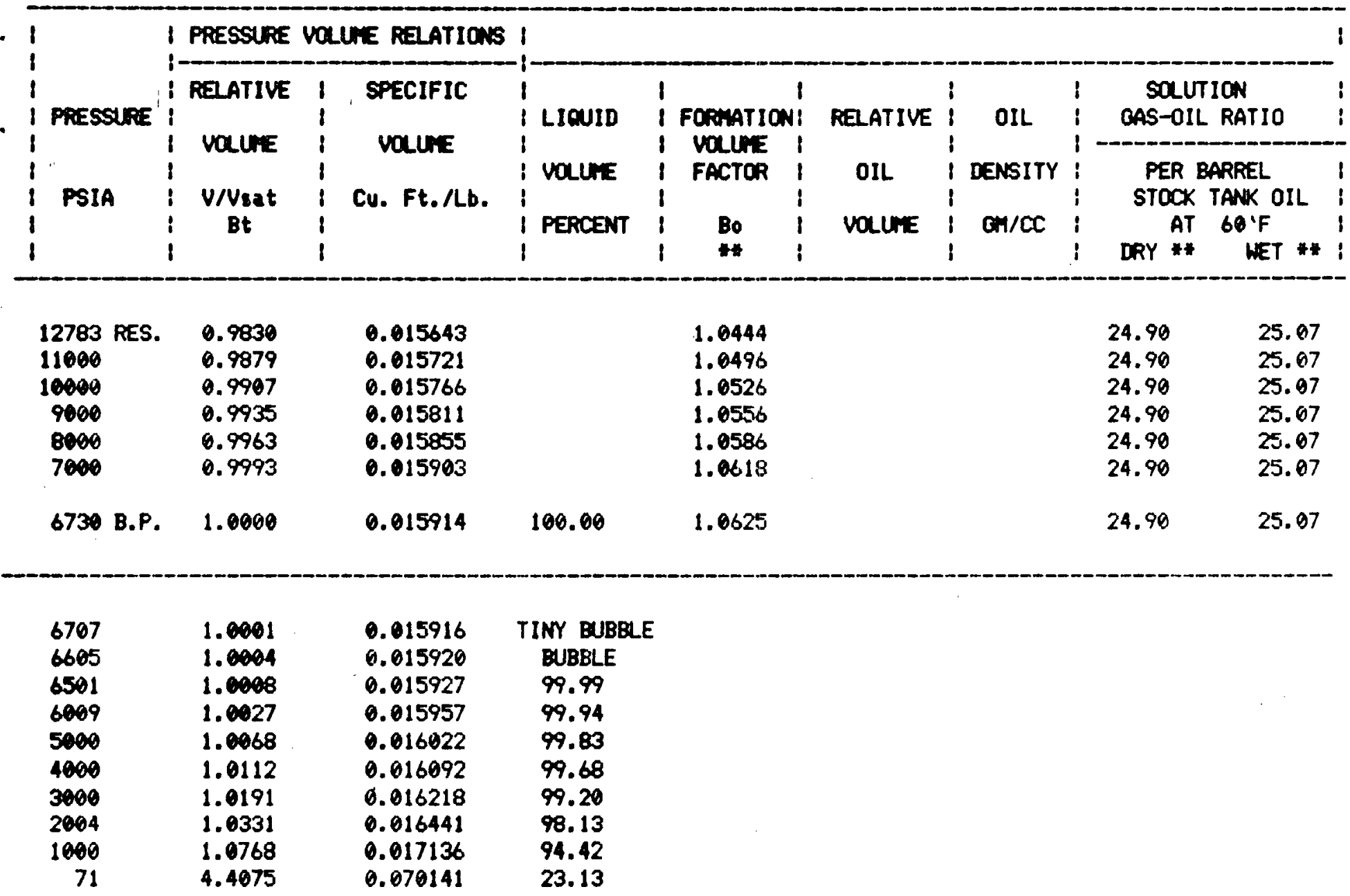

\section{NOHENCLATURE:}

V/USAT. IS THE VOLUNE OF FLUIDS (OIL AND GAS) AT THE INDICATED TEMPERATURE AND PRESSURE RELATIVE TO THE VOLUME OF SATLRATED OIL AT BUBBLE-POINT PRESSURE AND INDICATED TEMPERATURE.

BO IS THE VOLUME OF OIL AT RESERNOIR TEMPERATURE AND INDICATED PRESSLRE RELATIVE TO THE VOLURE OF EQUIVALENT STOCK TANK OIL NEASURED AT 60 DECREES F.

GAS-OIL RATIO, IS CUBIC FEET OF GAS AT 15.025 PSIA AND 60

DEGREES $F$, PER BARREL OF STOCK TANK OIL AT 60 DEGREES $F$.

NOTE: * BASED ON SEPARATOR WATER FLASH. REF. TO 'OIL' ABOVE SHOULD READ 'WATER'. 
TECHNADRIL-FENIX \& SCISSON, INC.

GLADYS MCCALL WELL NO. 1, SAND 8

EAST CRAB LAK'E FIELD

COMPOBITE LABOPATORY DATA 29 DECREES F

RECOMBINATION (2) 18.00 SCF SEP. GAS 15.025 PSIA \& 60'F/BBL. SEP. HATER Q SEP. CONDITIONS.

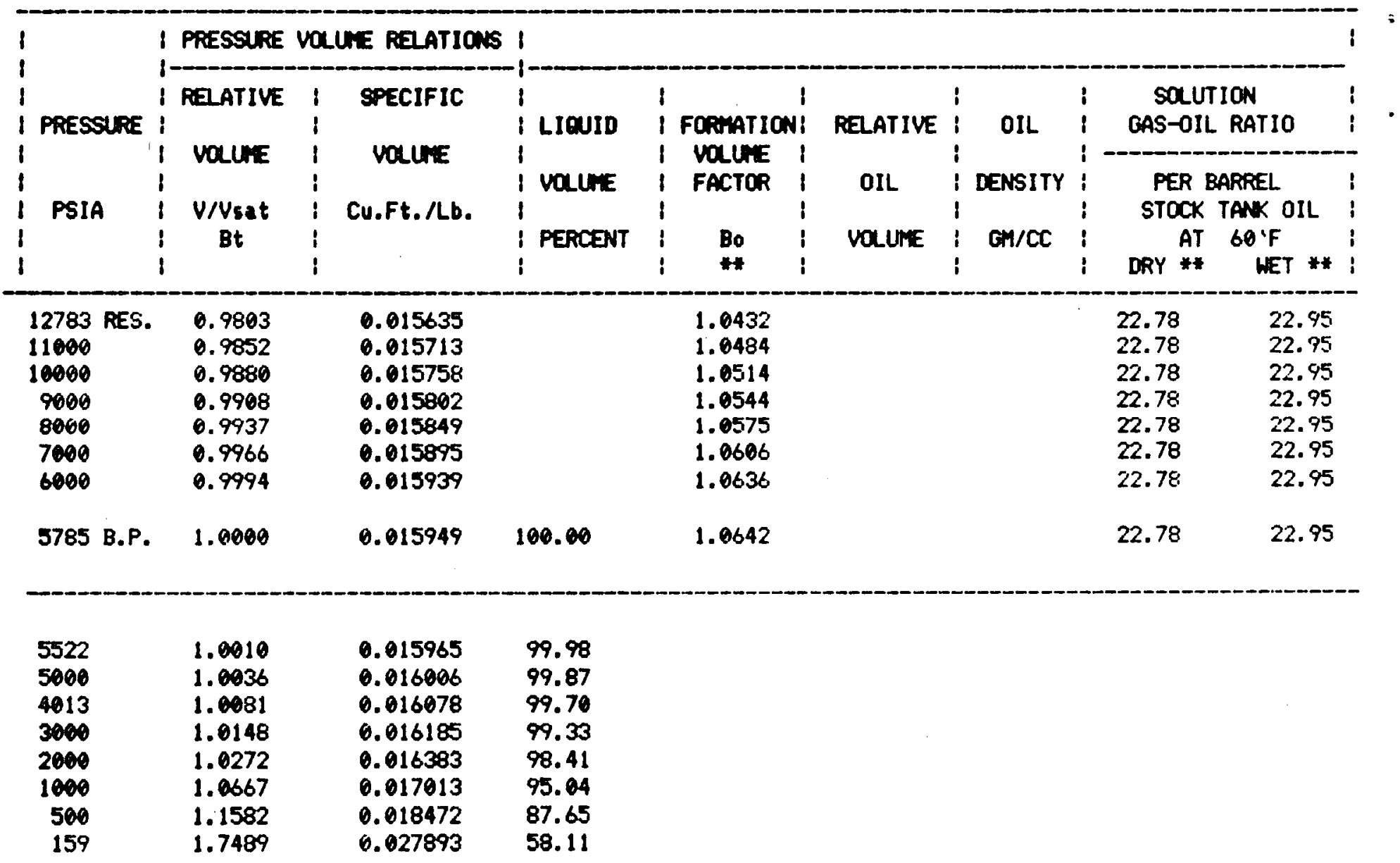

\section{NOHENCLATURE:}

U/VSAT. IS THE VOLLME OF FLUIDS (OIL AND GAS) AT THE INDICATED

TEMPERATURE AND PRESSURE RELATIVE TO THE VOLUME OF SATURATED

OIL AT BUBBLE-POINT PRESSLRE AND INDICATED TEMPERATURE.

Bo IS THE VOLUME OF OIL AT RESERNOIR TEMPERATURE AND INDICATED PRESSURE RELATIVE TO THE VOLUNE OF EQUIVALENT STOCK TANK OIL MEASURED AT 60 DEGREES F.

GAS-OIL RATIO, IS CUBIC FEET OF GAS AT 15.025 PSIA AND 60 DEGREES $F$, PER BARREL OF STOCK TANK OIL AT 60 DEGREES $F$.

NOTE: * BASED ON SEPARATOR WATER FLASH.

REF. TO 'OIL' ABONE SHOULD READ 'WATER'. 
TECHNADRIL-FENIX \& SCISSCIN, INC. GLADYS MCCALL WELL NO. 1, SAND 8

EAST CRAB LAKE FIELD

\section{COMPOSITE LABORATORY DATA 290 DECREES F}

RECOMBINATION (3) 15.00 SCF SEP. OAS 15.025 PSIA \& 60'F/BBL. SEP. WATER Q SEP. CONDITIONS.

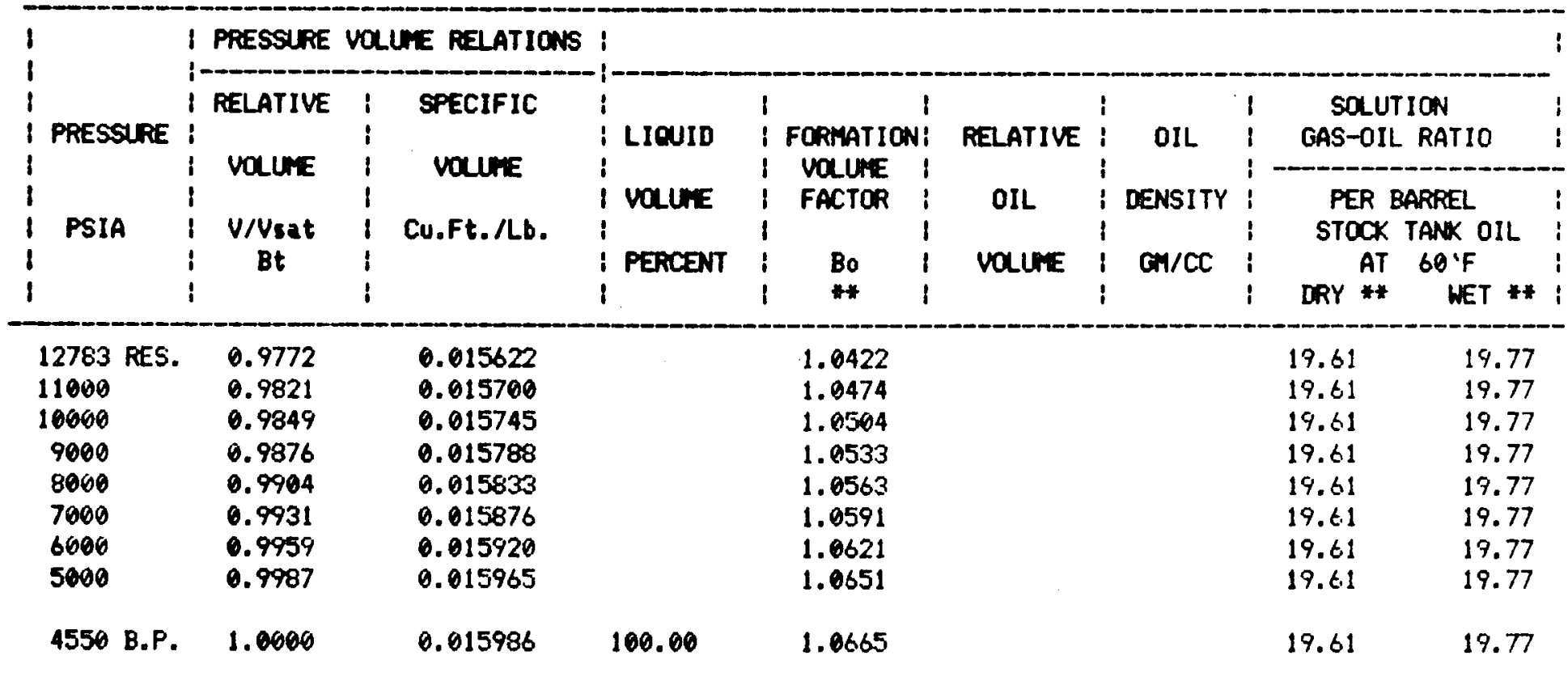

$\begin{array}{rrrr}4500 & 1.0002 & 0.015989 & \text { BUBBLE } \\ 4000 & 1.0022 & 0.016021 & 99.93 \\ 3500 & 1.0046 & 0.016060 & 99.84 \\ 3000 & 1.0080 & 0.016114 & 99.64 \\ 2000 & 1.0188 & 0.016287 & 98.86 \\ 1000 & 1.0526 & 0.016827 & 95.95 \\ 500 & 1.1318 & 0.018093 & 89.36 \\ 197 & 1.4605 & 0.023348 & 69.31\end{array}$

NOMENCLATURE:

V/USAT. IS THE VOLUNE OF FLUIDS (OIL AND GAS) AT THE INDICATED TEMPERATURE AND PRESSURE RELATIVE TO THE VOLLME OF SATURATED OIL AT BUEBLE-POINT PRESSURE AND INDICATED TEMPERATURE.

Bo IS THE VOLUME OF OIL AT RESERNOIR TEMPERATURE AND INDICATED PRESSURE RELATIVE TO THE VOLUME OF EQUIVALENT STOCK TANK OIL MEASURED AT 60 DEGREES F.

GAS-OIL RATIO, IS CUBIC FEET OF GAS AT 15.025 PSIA AND 60 DEGREES $F$, PER BARREL OF STOCK TANK OIL AT 60 DEGREES $F$.

NOTE: * BASED ON SEPARATOR WATER FLASH. REF. TO 'OIL' ABOVE SHOULD READ 'WATER'. 
TECHNALRIL-FENIX \& SCISSON, INC. GLADYS MCCALL WELL NO. 1, SAND 3 EAST CRAB LAKE FIELD

\section{COMPOSITE LABORATORY DATA 290 DECREES F}

RECOHBINATION (4) 10.00 SCF SEP. GAS 15.025 PSIA \& 60'F/BBL. SEP. WATER E SEP. CONDITIONS.

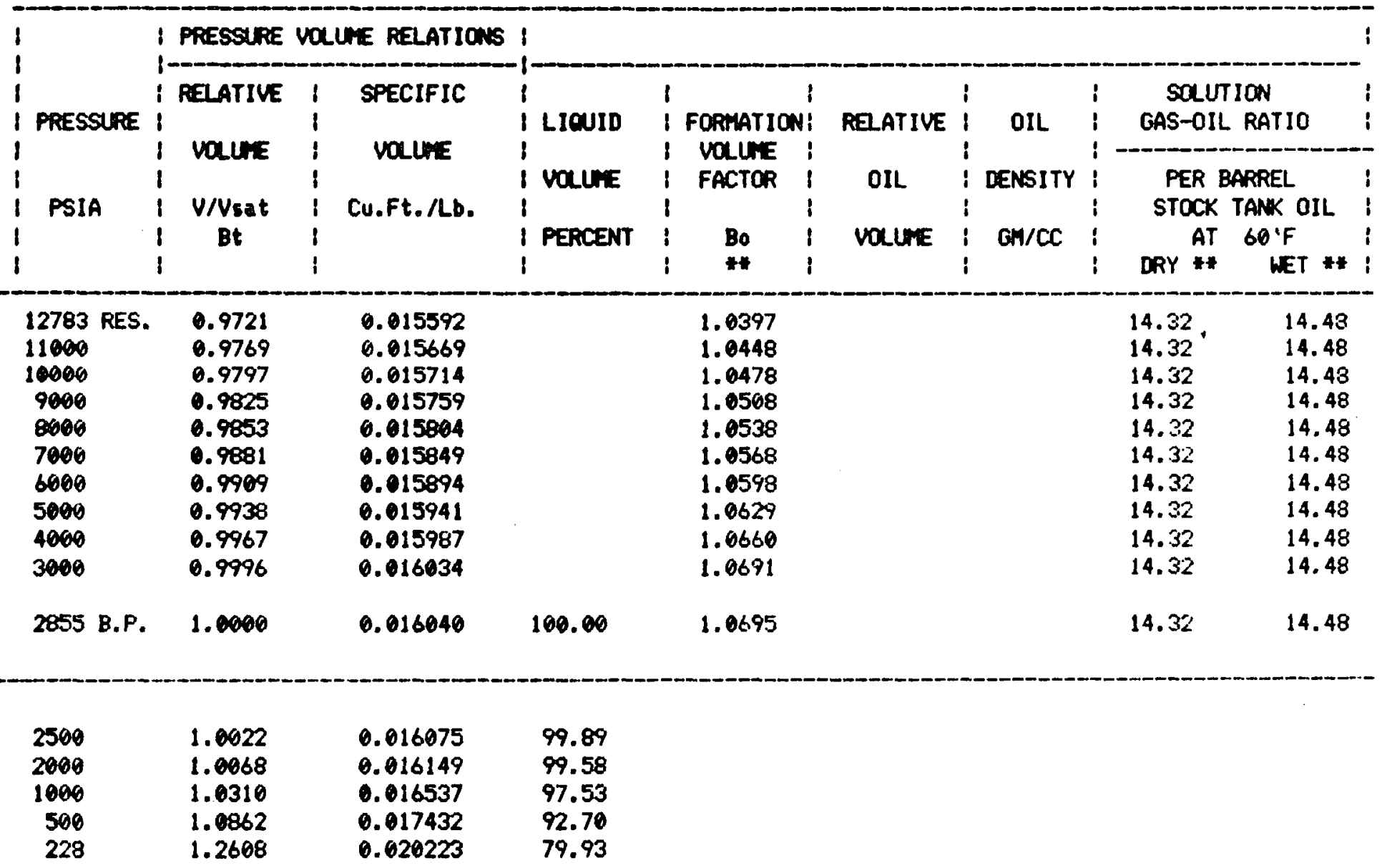

NOHENCLATURE:

V/USAT. IS THE VOLUME OF FLUIDS (OIL ANI GAS) AT THE INDICATEI TEMPERATURE AND PRESSURE RELATIVE TO THE VOLUME OF SATURATEL OIL AT BUBBELE-POINT PRESSURE AND INDICATED TEMPERATURE.

BO IS THE VOLUME OF OIL AT RESERVOIR TEMFERATURE AND INDICATED PRESSURE RELATIVE TO THE VOLUME OF EQUIVALENT STOCK TANK OIL MEASURED AT 60 DEGREES $F$.

GAS-OIL RATIO, 1S CUBIC FEET OF GAS AT 15.025 PSIA AND 60 DEGREES $F$, PER BARREL OF STOCK TANK OIL AT 60 DEGREES $F$.

NOTE: * BASED ON SEPARATOR WATER FLASH. REF. TO 'OIL' ABOVE SHOULD READ 'WATER'. 
TECHNADRIL-FENIX \& SCISSON, INC. GLADYS MCCALL WELL NO. 1 , SAND 8 EAST CRAB LAKE FIELD

\section{COMPOSITE LABORATORY DATA 290 DECREES F}

RECOMBINATION (5) 25.01 SCF SEP. GAS Q 15.025 PSIA \& 60'F/BEL. SEP. HATER Q SEP. COND. - PRODUCED GWR

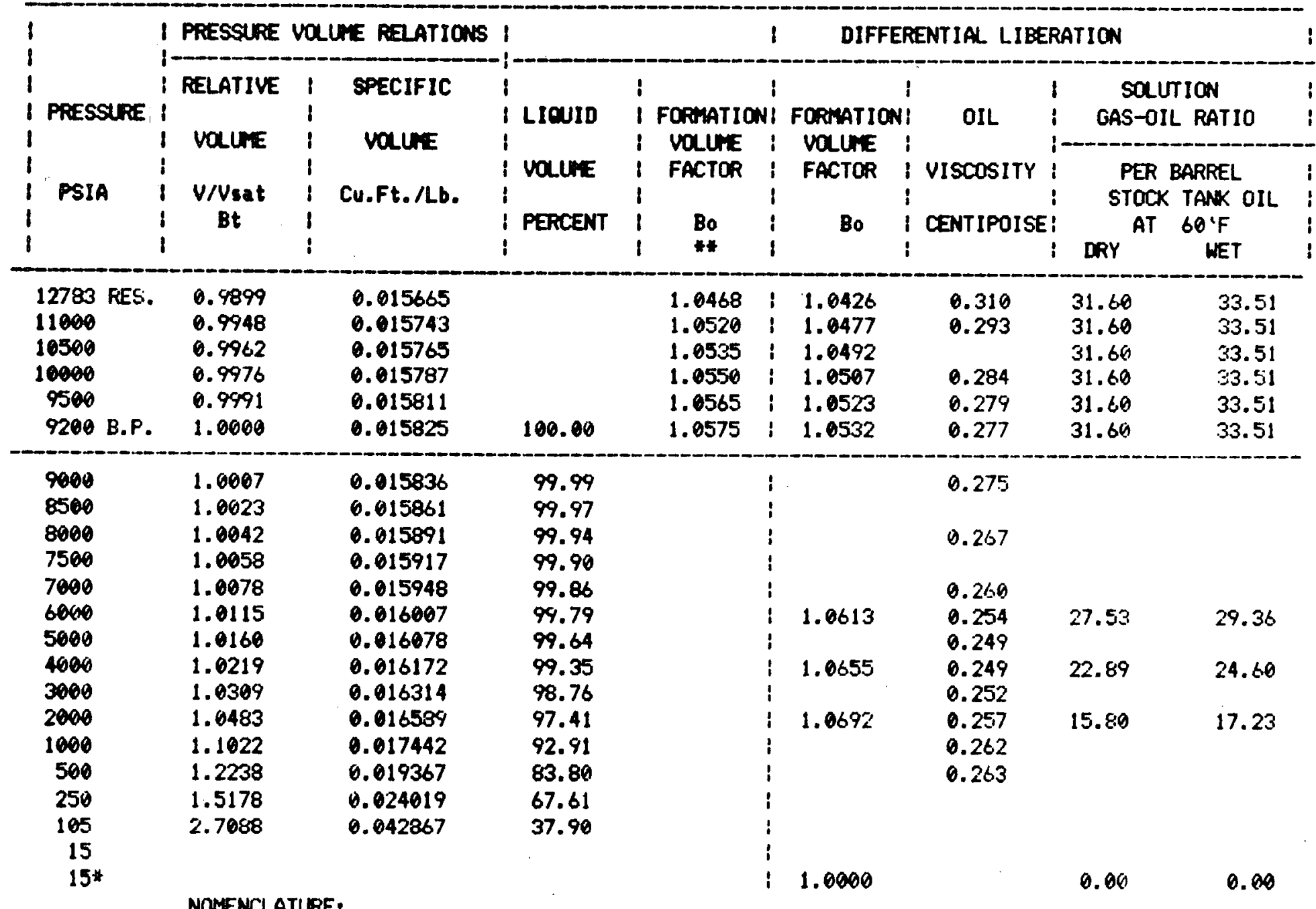

V/USAT. IS THE VOLUTE OF FLUIBS (OIL AND GAS) AT THE INDICATED TEMPERATURE AND PRESSURE RELATIVE TO THE VOLUME OF SATURATED OIL AT BUBBLE-FOINT PRESSURE AND INDICATED TEMPERATURE.

BO IS THE VOLLME OF OIL AT RESERVOIR TEMPERATURE AND INDICATED PRESSURE RELATIVE TO THE VOLUME OF EQUIVALENT STOCK TANK OIL MEASURED AT 6O DEGREES F.

GAS-OIL RATIO, IS CUBIC FEET OF CAS AT 15.025 PSIA AND 60 DEGREES $F$, PER BARREL OF STOCK TANK OIL AT 60 DEGREES $F$.

note: * indicates valle measured 2 60'F

* BASED ON SEPARATOR WATER FLASH

ALSO BASED ON SEP. WATER FLASH: SOLUTION GAS IN RES. FLD. IS

30.19 SCF DRY GAS/BBL. S.T. WATER E GQ' $F$ 30.38 SCF WET GAS/BBL. S.T. WATER 60'F

REF. TO "OIL" ABOVE SHOULD READ "WATER" 
TECHNADRIL-FENIX \& SCISSON, INL. GLADYS MCCALL WELL NO. 1 , GAND 8 EAST CRAB LAKE FIELD

\section{EFECT OF OAS-WATER RATIO UPON BUBELE POINT PRESSHRES $290^{\prime} \mathrm{F}$}

GAS-WATER RATIO

(SCF SEP. GAS 15.025 PSIA $760^{\circ} \mathrm{F}$ )

(BBA. SEP. WATER 500 PSIG \& 268)

* 31.9 EXTRAPQLATED

25.01 (PRODUCED)

20.00

18.00

15.00

10.60
BUBBLE POINT

(PSIA)

12783 RES. PRESSURE

9200

6730

5785

4550

2855 
TECHNADRIL-FENIX \& SC:ISSCIN, INC. GLADYS MCCALL WELL NO. 1, SAND 8 EAST CRAB LAKE FIELD

\section{SEPARATOR WATER FLASH TO O PSIO \& 78' $F$}

SOLUTION GAS-WATER RATIO, DRY = 3.75

$$
\begin{aligned}
& \text {, WET }=3.88 \text { SCF CAS } 15.025 \text { PSIA \& 60' F } \\
& \text { BBL. WATER O PSIG \& } 60 \text { ' } \mathrm{F}
\end{aligned}
$$

SHRINKAGE

$$
=0.9437
$$

VOL. S.T. HATER 69'F

WLL. SEP. H20 500 PSIGi \& 26.8'F

STOCK TANK WATER DENSITY

$$
=1.0656
$$

Gm/MI. $60^{\prime} \mathrm{F}$

GAS GRAVITY

$$
\begin{aligned}
& \text {, DRY }=0.9729 \\
& \text {, WET }=0.9590
\end{aligned}
$$$$
\text { (SEE ANALYSIS ON PAGE 15) }
$$

PRODUCED OCTOBER 8, 1983:

$$
\begin{aligned}
& \text { GWR }=26.44+3.75=30.19 \text { SCF TOTAL DRY GAS 15.025 PSIA \& 60'F } \\
& \text { BBL. STOCK TANK. WAIER O G0' } \mathrm{F} \\
& \text { GHR }=2450+3.88=30.38 \text { SCF TOTAL WET GAS } 15.025 \text { PSIA \& } 60^{\prime} F \\
& \text { BBL. STOCK TANK WATER } Q 60^{\prime} \mathrm{F}
\end{aligned}
$$


TECHNADRIL-FENIX \& SCISSON, INC. GLADYS MCCALL WELL NO. 1, SAND 8 EAST CRAB LAKE FIELD

\section{SEPARATOR GAS SAMPLED:}

OCTOBER 8, 1983 ?

500 PSIG \& $97^{\prime} \mathrm{F}$

\section{CHROMATOCRAPHIC ANLYSIS}

DRY

WET

MOLE
WATER

CARBON DIOXIDE

NITROGEN

METHANE

ETHANE

PROPANE

ISO-BUTANE

N-BUTANE

ISO-PENTANE

N-PENTANE

HEXANES

HEPTANES PLUS

TOTAL

GRAVITY (AIR $=1.00)$
10.63

0.25

85.96

2.34

0.52

0.09

0.07

0.02

0.01

0.00

0.11

100.00

0.6813
$0.22 \pm .04$

10.61

0.25

85.77

2.33

0.52

0.09

0.07

0.02

0.01

0.00

0.11

100.00

NOTE: WATER VAPOR MEASURED ON SITE, AVERAGE 5 RUNS. 
TECHWADRIL-FENIX \& SCISSON, INC. GLADYS MCCALL WELL NO. 1 , SAND 8 EAST CRAB LAKE FIELD

SOLUTION GAS FROM

SEPARATOR HATER FLASH

- PSIG \& 78'F

(CALCULATED NITROCEN FREE)

CHROMATOCRAPHIC ANALYSIS

$\begin{array}{lcc}\text { WATER } & - & 3.24 \\ \text { CARBON DIOXIDE } & 39.89 & 38.60 \\ \text { NITROSEN } & - & - \\ \text { METHANE } & 57.73 & 55.86 \\ \text { ETHANE } & 1.39 & 1.34 \\ \text { PROPANE } & 0.19 & 0.18 \\ \text { ISO-BUTANE } & 0.02 & 0.02 \\ \text { N-BUTANE } & 0.02 & 0.02 \\ \text { ISO-PENTANE } & 0.00 & 0.00 \\ \text { N-PENTANE } & 0.00 & 0.60 \\ \text { HEXANES } & 0.00 & 0.00 \\ \text { HEPTANES PLUS } & 0.76 & 0.74 \\ \text { TOTAL } & -0.9729 & 100.00 \\ \text { GRAVITY (AIR }=1.00) & 1000 & 0.9590\end{array}$

MOLE \%

WET

-

CRAVITY (AIR $=1.00)$ 
TECHNADRIL-FENIX ST:ISSON, INC. GLADYS MCCALL WELL NO. 1 , SAND 8 EAST CRAB LAKE FIELD

\section{SOLUTION GAS FRON}

6000 PSIA SAMPLE -

DIFFERENITAL LIBERATION

(CALCILATED NITROCEN FREE)

CHROMATOCRAPHIC ANALYSIS

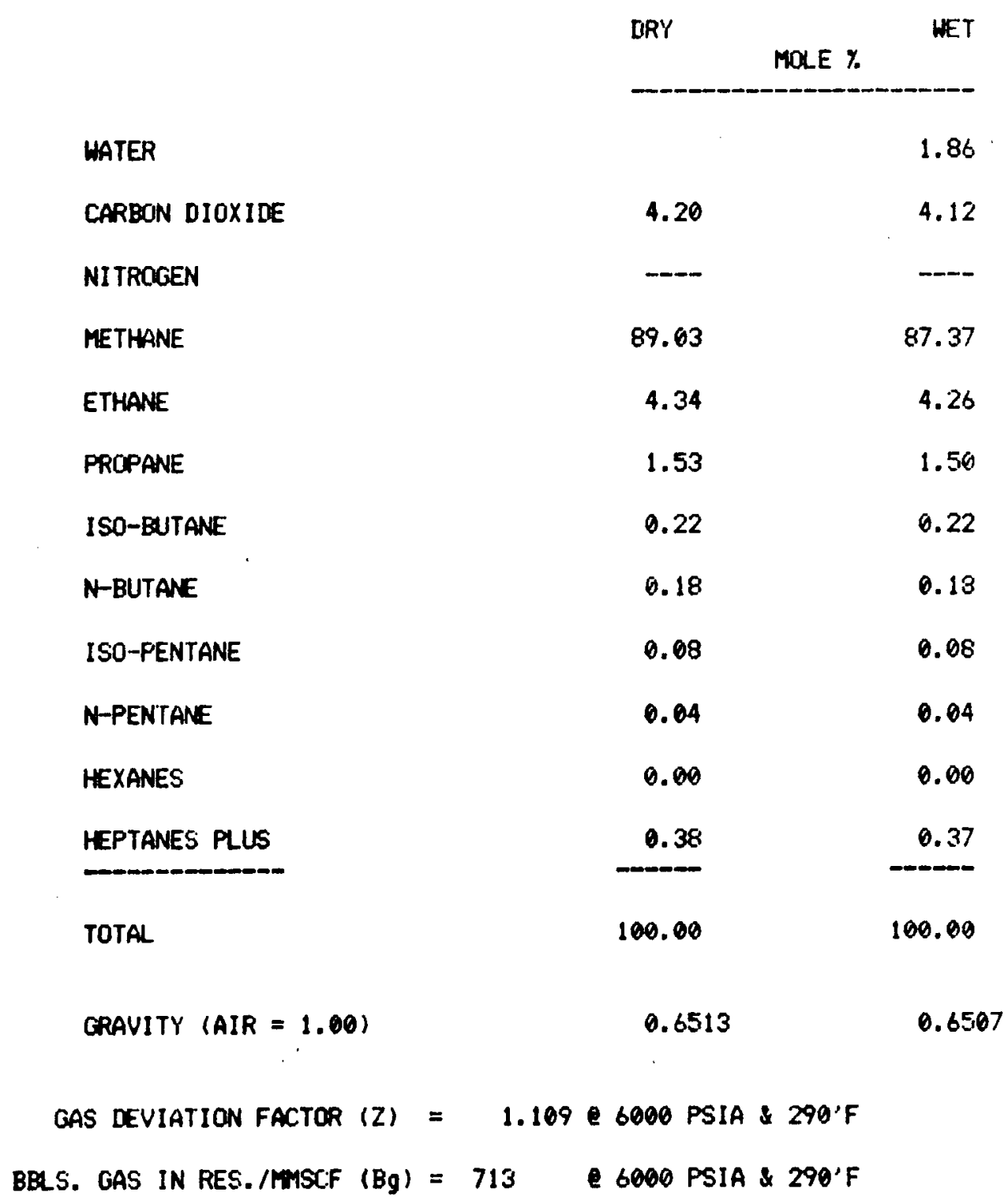


TECHNADRIL-FENIX \& SCISSON, INC. GLADYS MOCALL WELL NO. 1, SAND 8 EAST CRAB LAKE FIELD

\section{SOUUTION GAS FROM 4000 PSIA SAMPLE - DIFFERENITAL LIBERATION (CALCULATED NITROGEN FREE)}

\section{CHROMATOGRAPHIC ANALYSIS}

DRY WET MOLE \%

\section{WATER}

CARBON DIOXIDE

NITROGEN

METHANE

ETHANE

PROPANE

ISO-BUTANE

N-BUTANE

ISOIPENTANE

N-PENTANE

HEXANES

hEPTANES PLUS

TOTAL

$\begin{array}{ll}2.53 \\ 3.10 & 3.02 \\ \cdots & \end{array}$

91.74

89.42

$$
3.50
$$

3.41

0.99

0.96

0.19

0.19

0.13

0.13

0.04

0.04

0.02

0.02

0.00

0.00

0.29

0.28

100.00

100.00

GRAVITY (AIR $=1.00)$

0.6260

0.6259

BBLS. GAS IN RES. /MHSCF $(B g)=962$

e 4000 PSIA \& 290'F 
TECHNADRIL-FENIX \& SCISSCIN, INC. GLADYS MCCALL WELL NO. 1, SAND 8 EAST CRAB LAKE FIELD

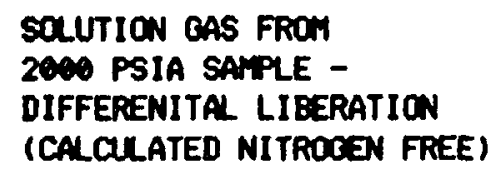

CHROMATOCRAPHIC AMALYSIS

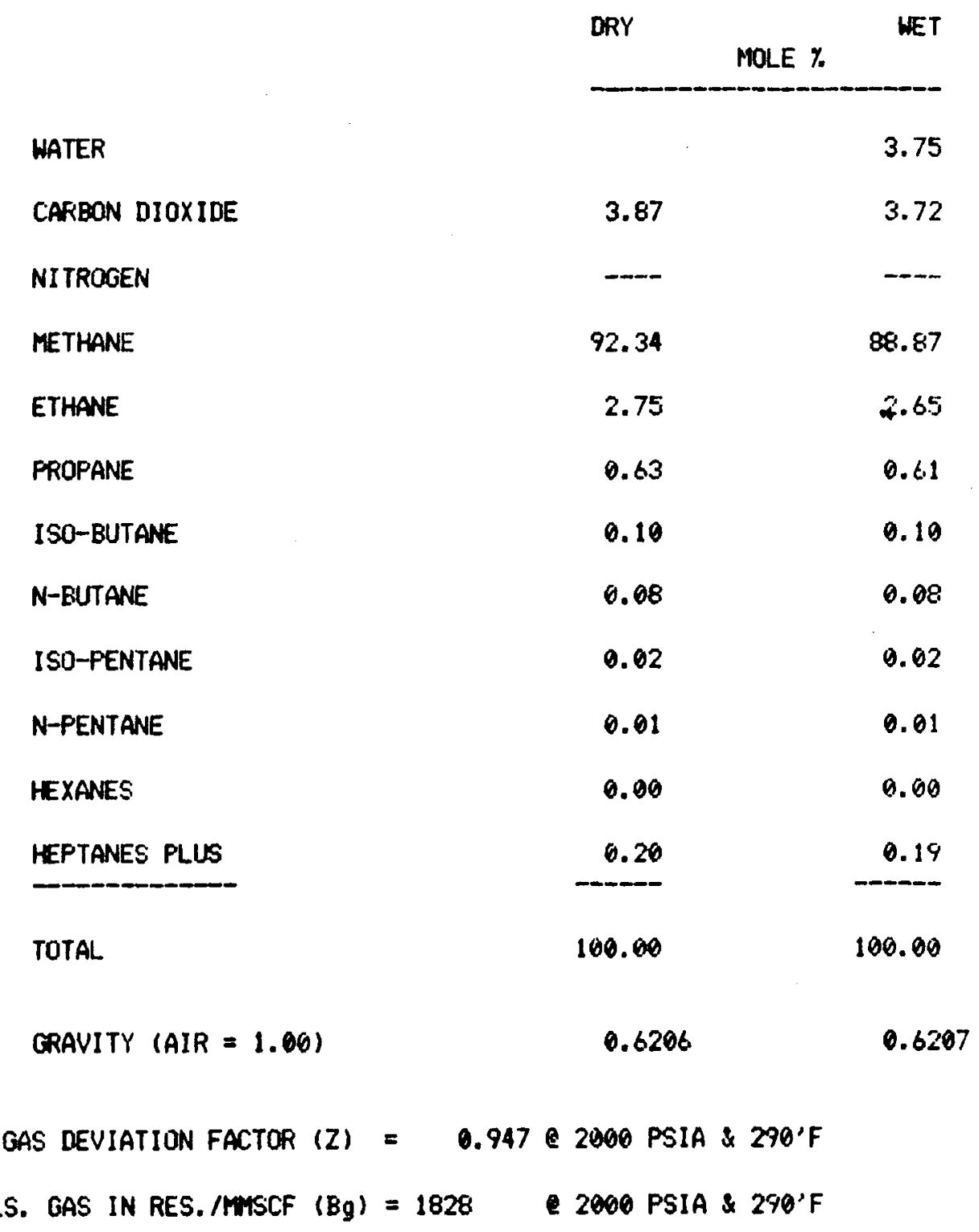


TECHNADRIL-FENIX \& SCISSON, INC. GLADYS MOCALL WELL NO. 1, SAND 8 EAST CRAB LAKE FIELD

\section{SOLUTION GAS FROH \\ 15 PSIA SAMPLE - \\ DIFFERENITAL LIBERATION \\ (CALCULATED NITROOEN FREE)}

CHROMATOCRAPHIC ANALYSIS

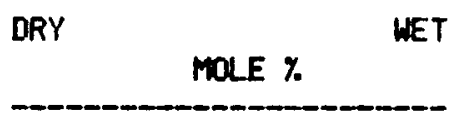

WATER

CARBCAN DIOXIDE

NITRCGEN

METHANE

ETHANE

PROPANE

ISO-BUTANE

N-EUTANE

ISO-PENTANE

N-PENTANE

HEXANES

HEPTANES PLUS

TOTAL
24.79

8.32

\section{(24.79}

73.93

67.78

1.06

0.97

0.11

0.10

0.00

0.09

0.00

0.00

0.00

0.00

0.00

0.00

0.00

0.00

0.11

0.10

100.00

100.00

GRAVITY $(A I R=1.00)$

0.8032

0.7881

GAS DEVIATION FACTOR $(Z)=1.000$ 15 PSIA \& $290^{\prime} \mathrm{F}$

BBLS. GAS IN RES. /MHAF $(B g)=256,893 \quad 15.025$ PSIA \& 290'F 
Company Technadril-Fenix \& Sc1sson well Gladys McCal1 No. 1 Reservoir Sand 8 Field East Crab Lake

FIG. 1: Effect of Gas-Water Ratio on Bubble Point Pressure (a 2900F

16

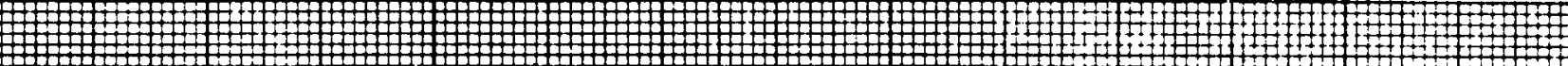

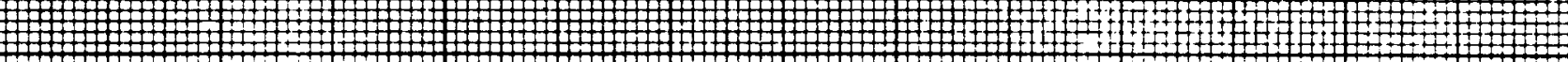
( (2)

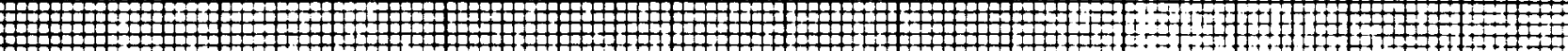

14 (1)

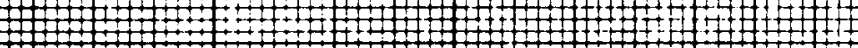

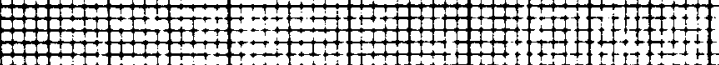

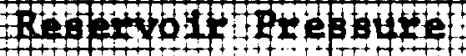

12

$1+14+2+1$

\section{4}

$1+1+1+1$

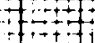

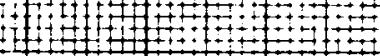

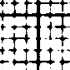

$+1+1$

$4+1$

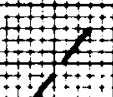
$\square$

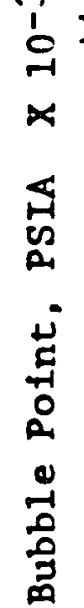

$+1$

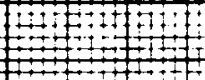

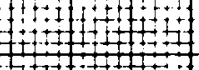

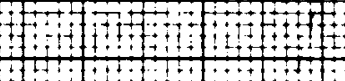

$+$

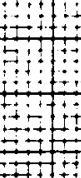

$14+1+1+1+140$

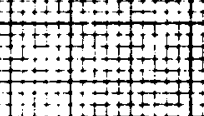

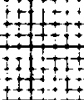
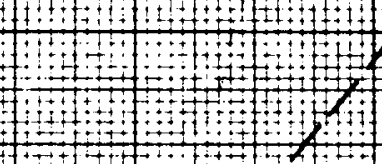

$++1+\div$

10
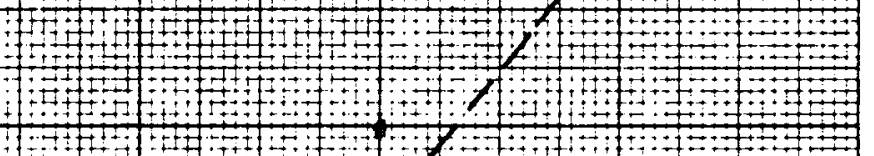

$\$$

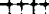

$+1+4$

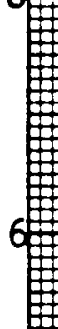

$10.1+1+1$

\#

4

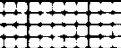

$1+1+1$

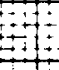

Irtitif

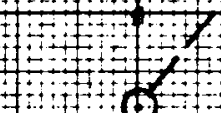

$40+1+2$

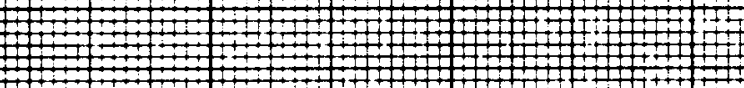

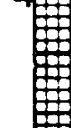
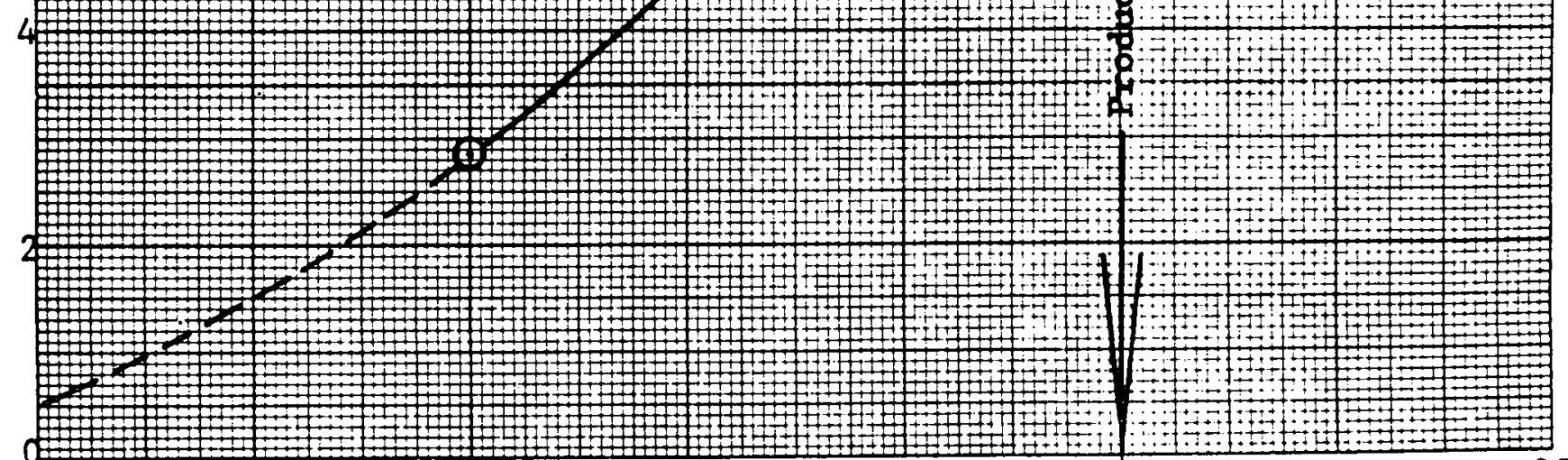

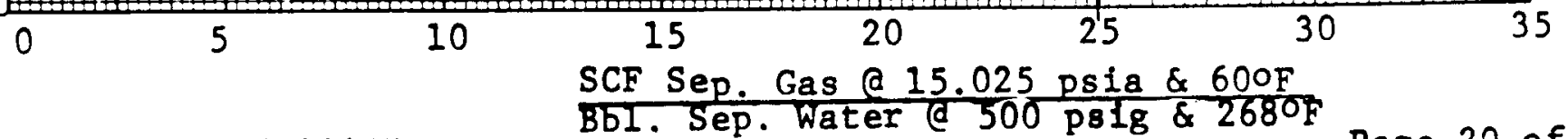

Lab. No. N2106-10457 
Company Technadril-Fenix \& Scisson Well Gladys McCall No. 1 Reservoir Sand 8 Field East Crab Lake

FIG. 2: Liq. Vol. \% vs. Pressure-Res. Water @ 2900F GWR $=25.01$

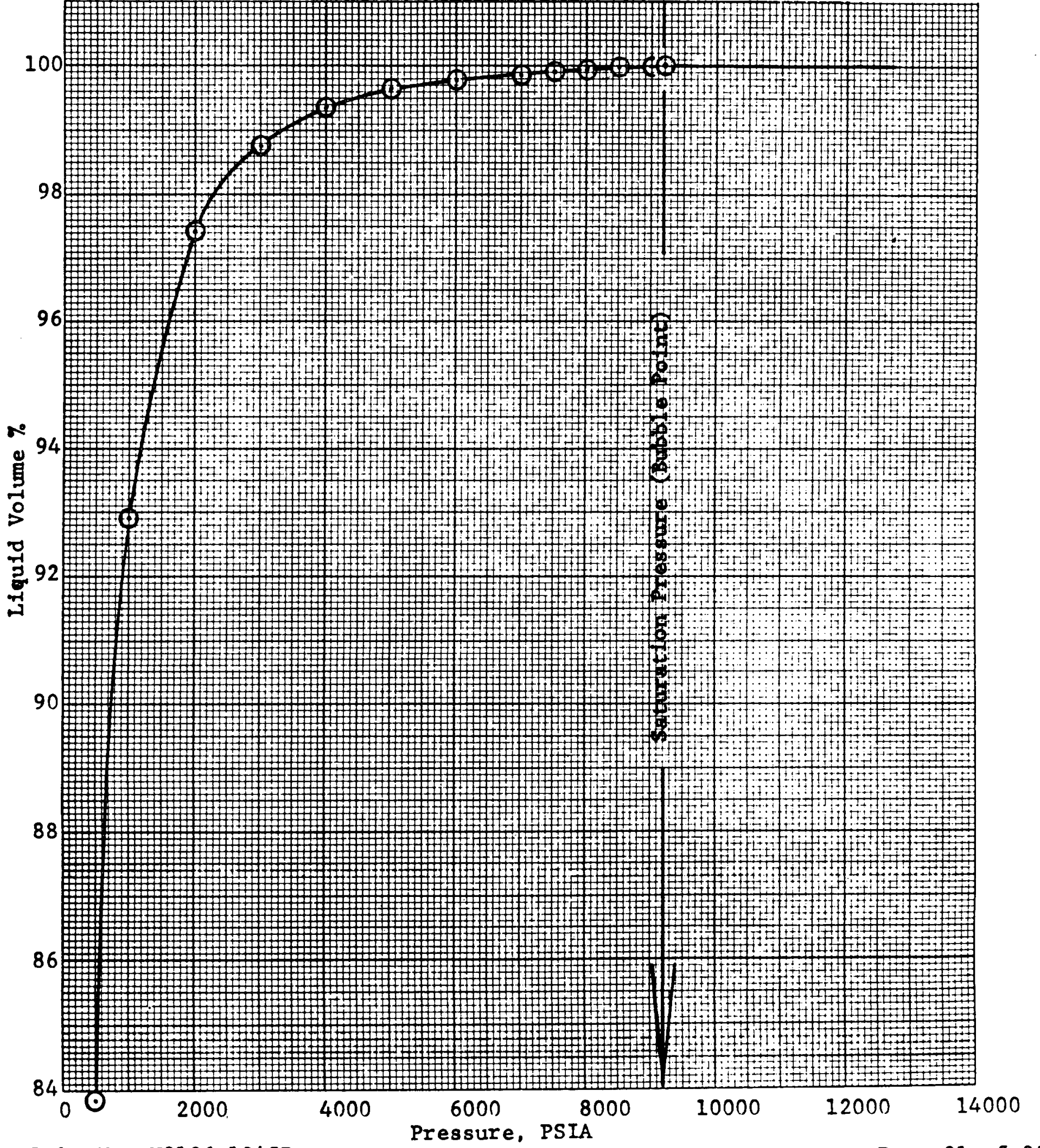

Lab. No. N2106-10457

Page 21 of 2 ? 


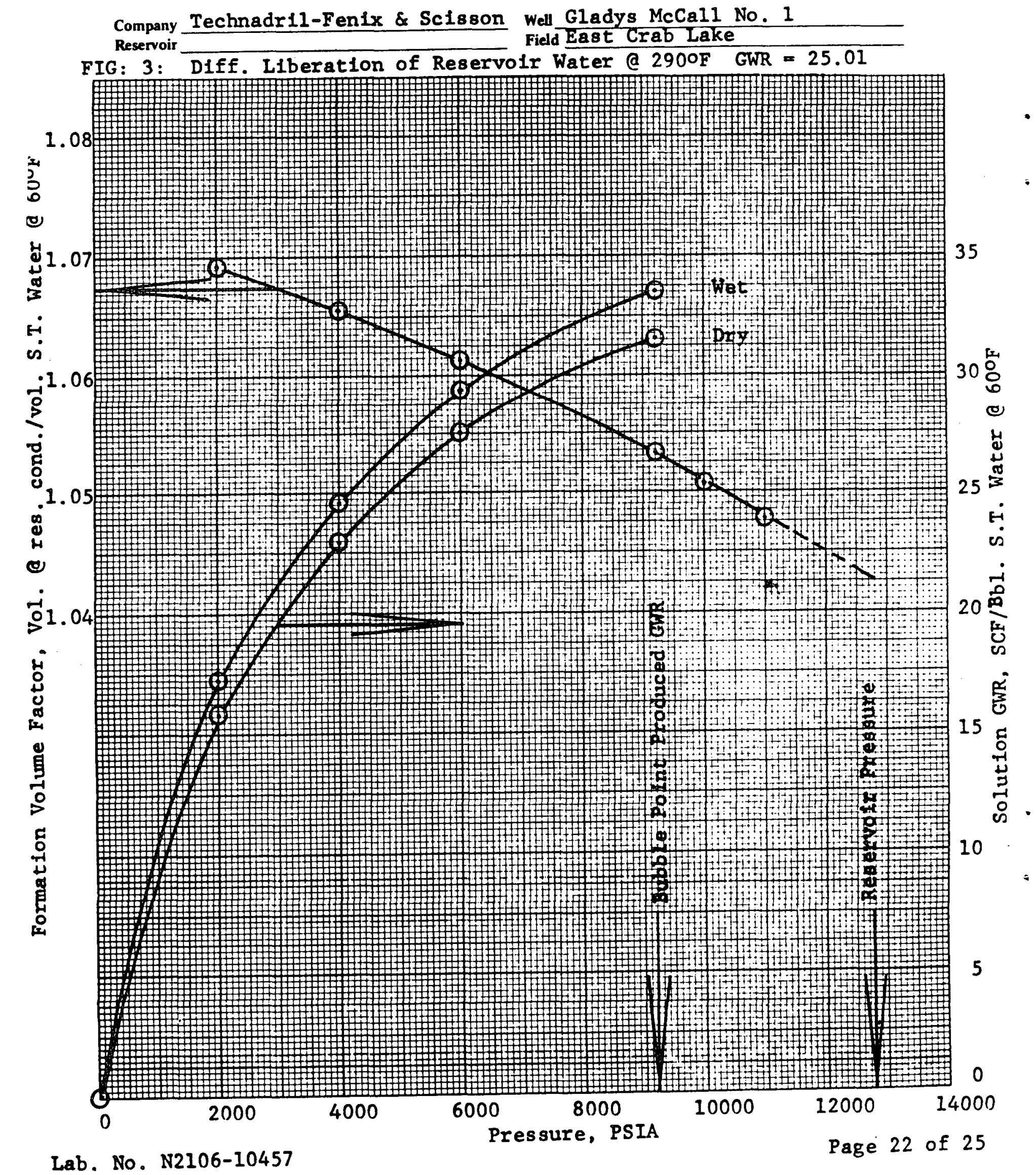


Company Technadril-Fenix \& Scisson Well Gladys McCall No. 1

FIG : 4: FVF \& Solution GWR of Saturated Water (Based on sep. water flash) a 2900F

1.08 W

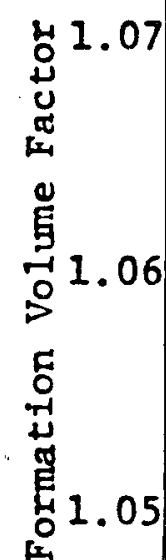

约

约 功

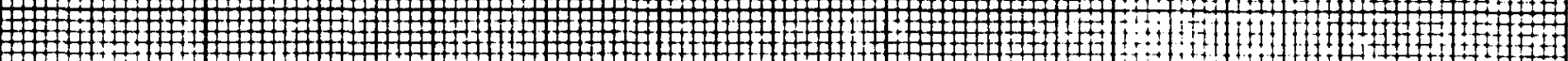

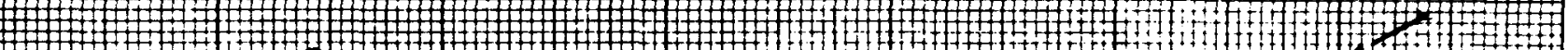

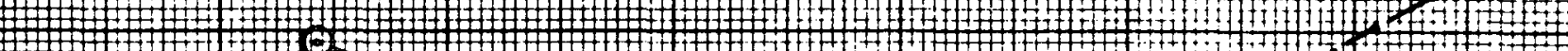

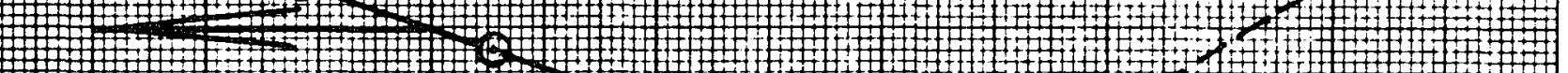

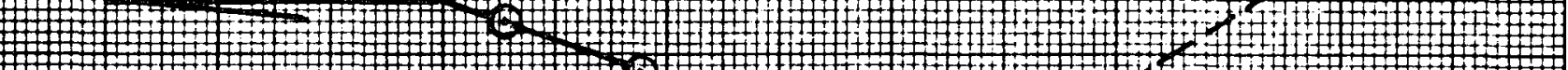

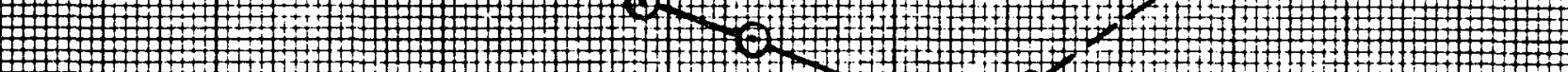

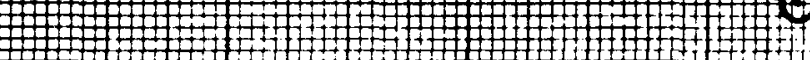

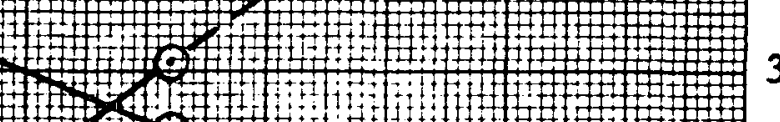

$30 \stackrel{1}{0}$

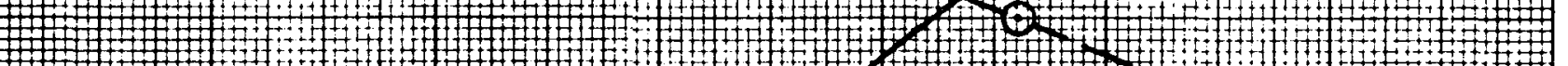

()

$1+1$

+214:

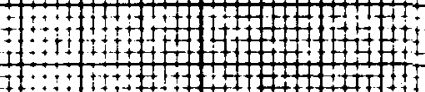

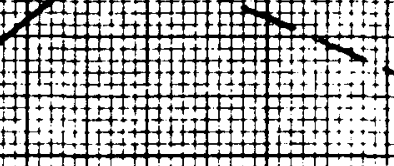
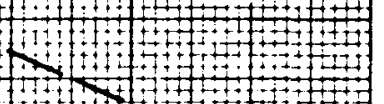

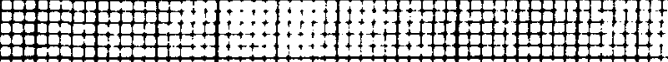

计

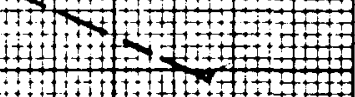

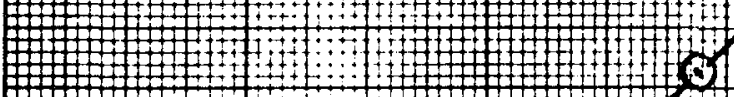

1.04

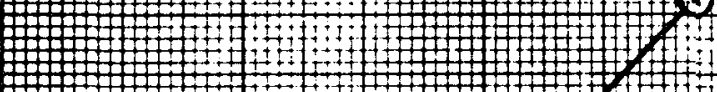
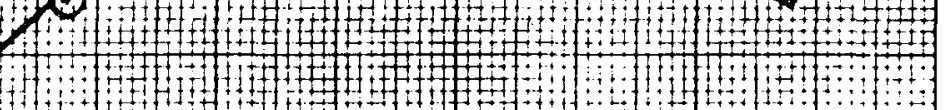

25

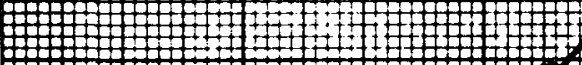

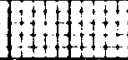

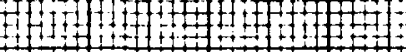

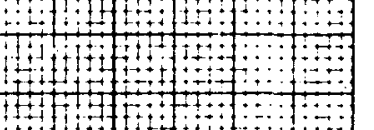

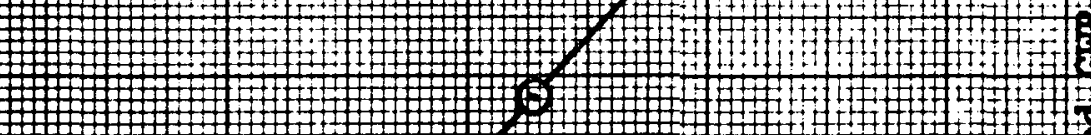

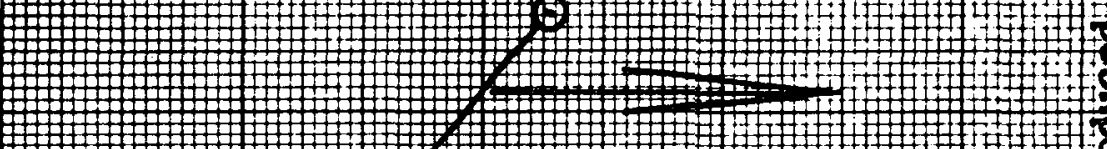

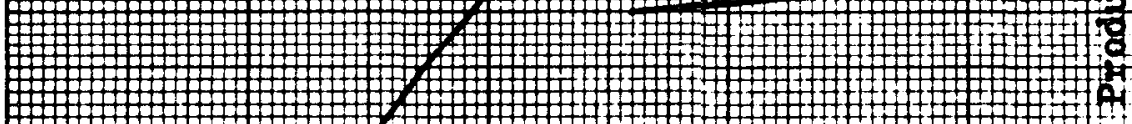

:

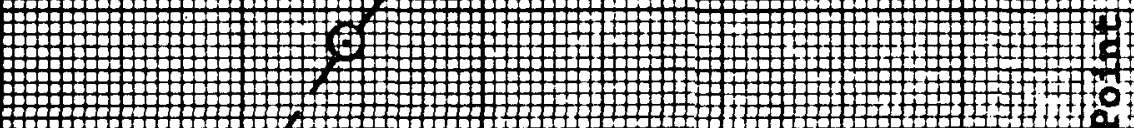

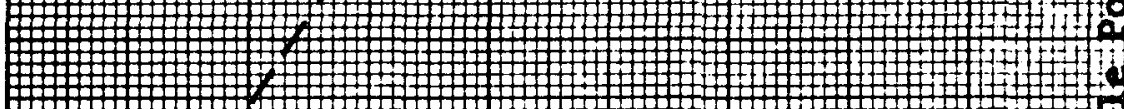

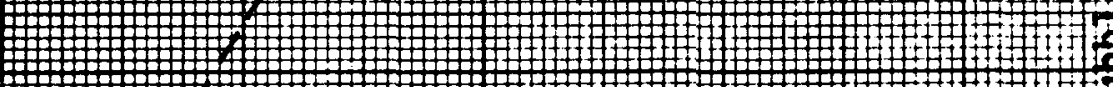

功

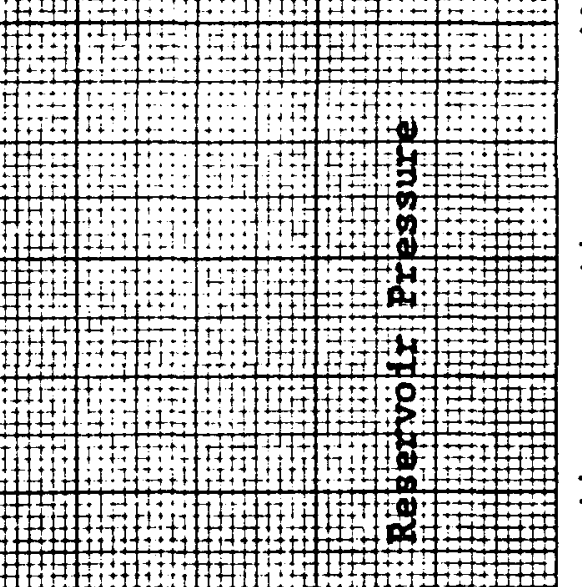

功

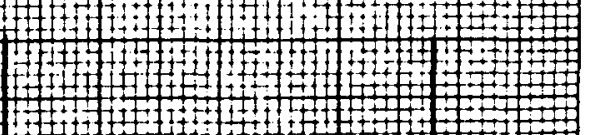

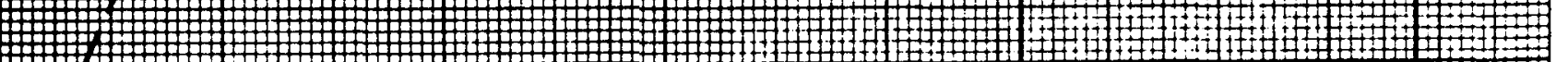

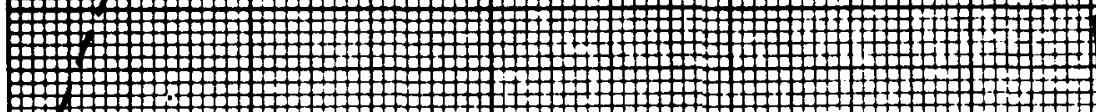

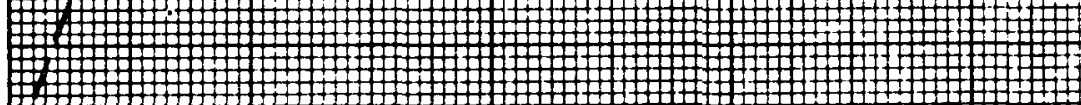

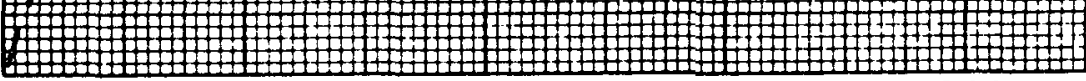

0

2000

4000

6000

8000

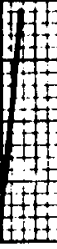

Lab. No. N2106-10457

Pressure, PSIA

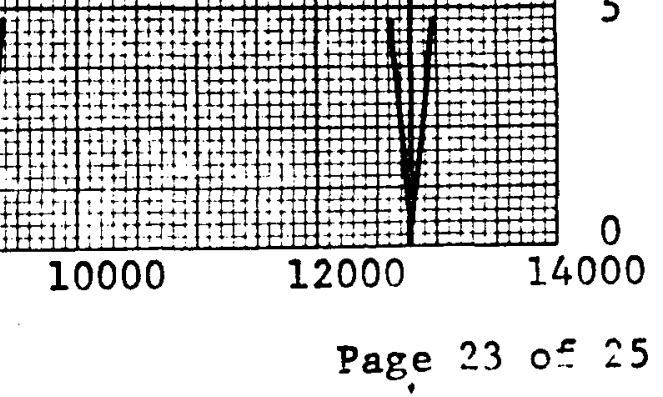


Company Technadr1l-Fenix \& Scisson Well Gladys McCal1 No. I Reservoir Sand 8 Field East Crab Lake

FIG: 5: Specific Volume of Saturated (Bubble Point) Water a $290 \mathrm{~F}$

.0163

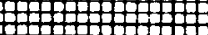

.0163

.0162

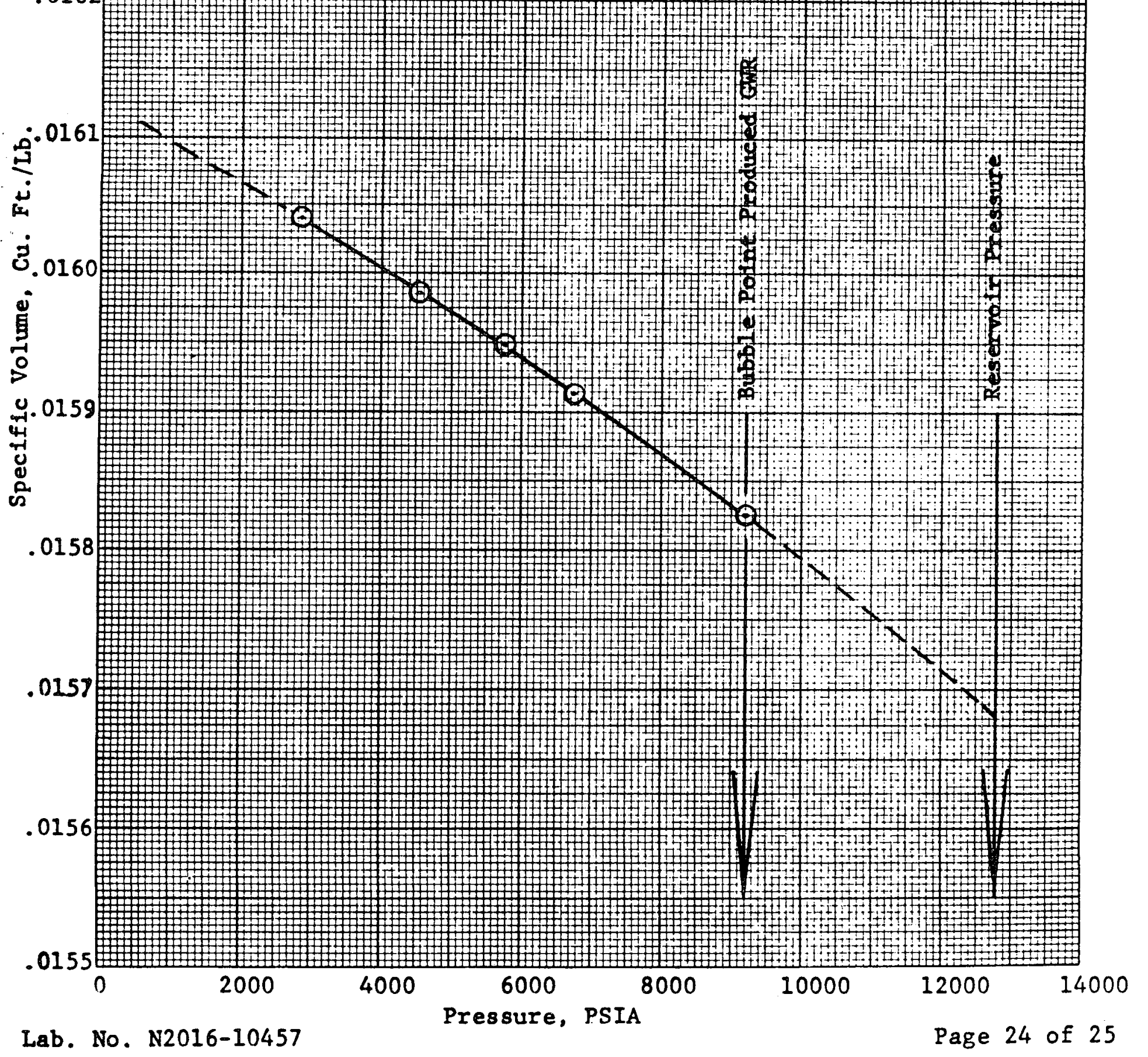

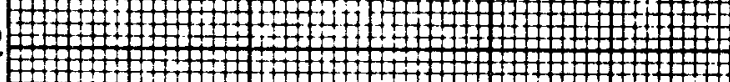

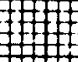

\#車

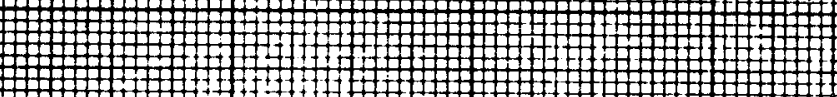

(

$+1+$

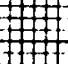




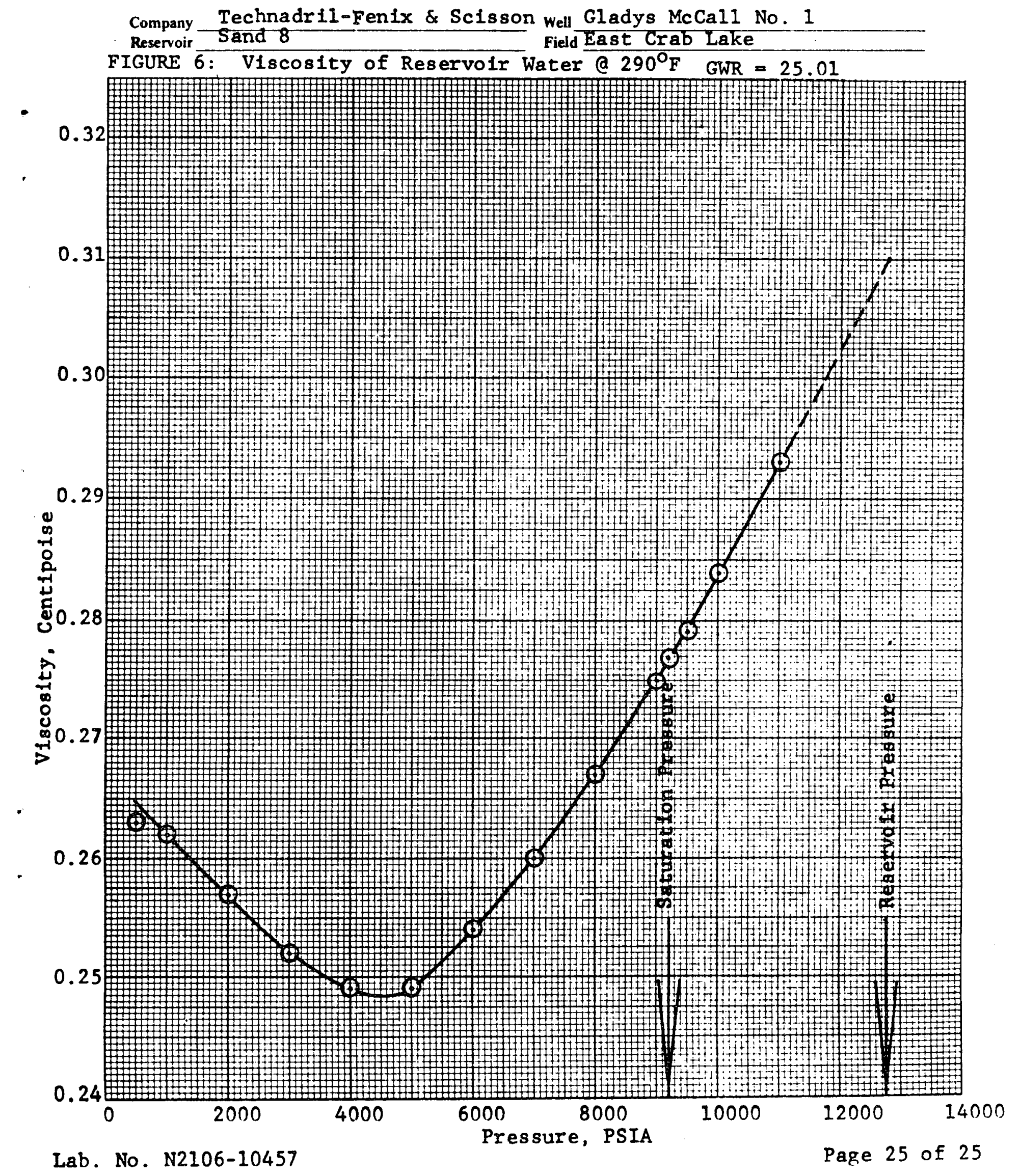


APPENDIX B

Gas Analysis by Sample Location 
THIS IS CHOLEE 1.

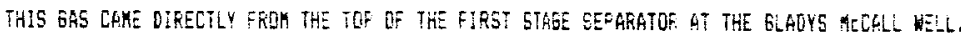

\begin{tabular}{|c|c|c|c|c|c|c|c|c|c|c|c|c|c|c|c|c|c|c|c|c|}
\hline $\begin{array}{l}\text { RECORD } \\
\text { NOD. }\end{array}$ & $\begin{array}{l}\text { NUNAEERS } \\
\text { IN RECORD }\end{array}$ & DATE & TIEE' & $\begin{array}{l}\text { TERP, } \\
\text { f }\end{array}$ & $\begin{array}{l}\text { PFESS, } \\
\text { PSIA }\end{array}$ & $\begin{array}{l}\text { GRAVITYZ } \\
\text { AIR }=1\end{array}$ & $\begin{array}{l}\text { GROSS HEATINEZ } \\
\text { VALLE, ETU/CF }\end{array}$ & $\begin{array}{l}\angle A B^{3} \\
N 0 .\end{array}$ & $\mathrm{CC2}$ & $\mathrm{N}_{2}$ & C1 & $\mathrm{C2}^{2}$ & {$[3$} & 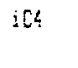 & $\pi i k$ & $i C 5$ & nec5 & $86+$ & TETA: & \\
\hline$=:=$ & $=\geq z= \pm$ & y=:=:==:=s= & $z= \pm=$ & $==$ & $== \pm=$ & $=== \pm=$ & $s=z=z$ & $== \pm=$ & : $=z=z$ & $== \pm==$ & $=z=z$ & $=:=z=$ & $== \pm==$ & $=z==$ & $== \pm=$ & $== \pm=$ & $==z=z$ & $==z=z$ & $s=z=z=$ & \\
\hline $\begin{array}{l}1 \\
1\end{array}$ & $\begin{array}{r}1-17 \\
18-25\end{array}$ & 9 Feb 1980 & $14: 45$ & 265 & 1024 & .6536 & 969 & 1 & 7.75 & .20 & 88.78 & $\begin{array}{r}2.41 \\
.657\end{array}$ & $\begin{array}{r}.55 \\
.154\end{array}$ & .09 & $\begin{array}{l}.065 \\
.026\end{array}$ & $\begin{array}{l}.02 \\
.067\end{array}$ & $\begin{array}{r}0.00 \\
0.000\end{array}$ & $\begin{array}{r}.22 \\
.050\end{array}$ & $\begin{array}{r}100.00 \\
.725\end{array}$ & $\begin{array}{l}\text { HLLL } \\
\text { GEY }\end{array}$ \\
\hline $\begin{array}{l}2 \\
2\end{array}$ & $\begin{array}{r}1-17 \\
1 E-25\end{array}$ & $9580 \div 936$ & $19: 15$ & 285 & 1025 & .6528 & 969 & 1 & 7.68 & .24 & 88.86 & $\begin{array}{l}2.39 \\
.652\end{array}$ & $\begin{array}{r}.35 \\
.154\end{array}$ & $\begin{array}{r}.08 \\
.027\end{array}$ & $\begin{array}{r}.08 \\
.026\end{array}$ & $\begin{array}{r}.02 \\
.007\end{array}$ & $\begin{array}{l}0.00 \\
0.000\end{array}$ & $\begin{array}{r}.12 \\
.650\end{array}$ & $\begin{array}{r}105.00 \\
.916\end{array}$ & $\begin{array}{l}\mathrm{MOLL} \\
\text { GFH }\end{array}$ \\
\hline $\begin{array}{l}3 \\
3\end{array}$ & $\begin{array}{r}1-17 \\
18-25\end{array}$ & $10 \mathrm{Fet} 1986$ & $13: 05$ & 294 & 1615 & .6562 & 973 & 1 & .74 & .24 & 88.64 & $\begin{array}{l}2.41 \\
.65 .7\end{array}$ & $\begin{array}{r}.56 \\
.357\end{array}$ & .09 & $\begin{array}{r}.018 \\
.026\end{array}$ & $\begin{array}{l}.02 \\
.007\end{array}$ & $\begin{array}{l}.01 \\
.004\end{array}$ & .21 & $\begin{array}{r}100.00 \\
.965\end{array}$ & $\begin{array}{l}M D L Z \\
G P M^{2}\end{array}$ \\
\hline $\begin{array}{l}4 \\
4\end{array}$ & $\begin{array}{r}1-17 \\
10-25\end{array}$ & 11 Fet 1986 & $10: 31$ & 306 & 1620 & .5596 & 970 & 1 & 7.78 & .23 & 85.52 & $\begin{array}{l}2.42 \\
.660\end{array}$ & $\begin{array}{r}.56 \\
.157\end{array}$ & $\begin{array}{r}.09 \\
.030\end{array}$ & $\begin{array}{r}.67 \\
.022\end{array}$ & $\begin{array}{r}.02 \\
.007\end{array}$ & .01 & $\begin{array}{r}.30 \\
.12 t\end{array}$ & $\begin{array}{r}160.60 \\
1.006\end{array}$ & $\begin{array}{l}\text { MLLI } \\
\text { BP!? }\end{array}$ \\
\hline $\begin{array}{l}5 \\
5\end{array}$ & $\begin{array}{r}1-17 \\
18-25\end{array}$ & 1. Fet 1786 & $11: 11$ & 289 & 1022 & $.6 t 2 t$ & 977 & 1 & 8.00 & .22 & 86.67 & $\begin{array}{l}2.54 \\
.692\end{array}$ & $\begin{array}{r}.63 \\
.177\end{array}$ & $\begin{array}{r}.12 \\
.040\end{array}$ & $\begin{array}{r}.10 \\
.132\end{array}$ & $\begin{array}{r}.03 \\
.011\end{array}$ & $\begin{array}{r}.01 \\
.004\end{array}$ & $\begin{array}{r}.28 \\
.117\end{array}$ & $\begin{array}{r}100.00 \\
1.674\end{array}$ & $\begin{array}{l}\text { MCLL } \\
\text { GPK' }\end{array}$ \\
\hline $\begin{array}{l}6 \\
6\end{array}$ & $\begin{array}{r}1-17 \\
18-25\end{array}$ & 11 Fet $1780^{\circ}$ & $21: 32$ & 291 & 1019 & .6629 & $\varphi 77$ & 1 & 8.01 & .33 & 83.12 & $\begin{array}{l}2.46 \\
.371\end{array}$ & $\begin{array}{r}.61 \\
.171\end{array}$ & .011 & $\begin{array}{r}.10 \\
.032\end{array}$ & $\begin{array}{r}.04 \\
.015\end{array}$ & .004 & $\begin{array}{l}.31 \\
.130\end{array}$ & $\begin{array}{r}106.00 \\
1.059\end{array}$ & $\begin{array}{l}\text { MOLI } \\
\text { EPH }\end{array}$ \\
\hline $\begin{array}{l}7 \\
7\end{array}$ & $\begin{array}{r}1-17 \\
16-25\end{array}$ & 11 Fes 1986 & $12: 21$ & 294 & $\operatorname{lin} 20$ & .6584 & 972 & $\mathrm{i}$ & 7.91 & .22 & 88.37 & $\begin{array}{l}2.48 \\
.576\end{array}$ & $\begin{array}{r}.60 \\
.163\end{array}$ & .111 & $\begin{array}{r}.09 \\
.029\end{array}$ & .03 & .01 & .18 & $\begin{array}{l}500.00 \\
1.00 !\end{array}$ & $\begin{array}{l}\text { ME: } \\
\text { BF } \mathrm{H}^{2}\end{array}$ \\
\hline $\begin{array}{l}8 \\
8\end{array}$ & $\begin{array}{r}1-17 \\
15-25\end{array}$ & 11 Feb 1936 & $14: 25$ & 302 & the & .6537 & 968 & 1 & $7.6 i$ & .22 & 80.74 & $\begin{array}{l}2.40 \\
.654\end{array}$ & $\begin{array}{r}.54 \\
.15 i\end{array}$ & .090 & $\begin{array}{r}.07 \\
.072\end{array}$ & .62 & $\begin{array}{r}.01 \\
. \$ 4\end{array}$ & $\begin{array}{r}.10 \\
.642\end{array}$ & $\begin{array}{r}10.60 \\
.911\end{array}$ & $\begin{array}{l}\mathrm{MML} \\
\mathrm{SPH}\end{array}$ \\
\hline $\begin{array}{l}9 \\
9\end{array}$ & $\begin{array}{r}1-17 \\
15-25\end{array}$ & 13 Apr 1967 & vg: $4 \tilde{3}$ & 284 & 1013 & .6551 & 963 & : & 8.67 & .24 & 88.50 & $\begin{array}{l}2.42 \\
.660\end{array}$ & $\begin{array}{r}.53 \\
.149\end{array}$ & .08 & .07 & $\begin{array}{r}.02 \\
.007\end{array}$ & .007 & .05 & $\begin{array}{r}000,00 \\
.894\end{array}$ & $\begin{array}{l}\text { MoL: } \\
6 P y^{2}\end{array}$ \\
\hline $\begin{array}{l}10 \\
10\end{array}$ & $\begin{array}{r}1-17 \\
16-25\end{array}$ & 13 Apr 1967 & $10: 00$ & 284 & 515 & .685 & 929 & 1 & 11.31 & .23 & 85.43 & $\begin{array}{l}.31 \\
.630\end{array}$ & $\begin{array}{r}.49 \\
.133\end{array}$ & .07 & .1.5 & $\begin{array}{r}.02 \\
.067\end{array}$ & .61 & .68 & $\begin{array}{r}10.60 \\
.851\end{array}$ & 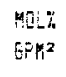 \\
\hline $\begin{array}{l}11 \\
11\end{array}$ & $\begin{array}{l}t-17 \\
1 \bar{E}-25\end{array}$ & 14 Apr 198 ? & $07: 5 i$ & 230 & 515 & .6523 & 931 & 1 & 10.99 & .27 & 8.7 .77 & $\begin{array}{l}2.26 \\
.616\end{array}$ & $\begin{array}{l}.47 \\
.132\end{array}$ & .07 & .05 & $\begin{array}{l}.02 \\
.067\end{array}$ & .007 & $\begin{array}{r}.07 \\
\therefore 29\end{array}$ & $\begin{array}{r}10.50 \\
.25\end{array}$ & $\begin{array}{l}\text { MOL: } \\
\text { GFY? }\end{array}$ \\
\hline $\begin{array}{l}! 2 \\
! 2\end{array}$ & $\begin{array}{l}1-17 \\
26-25\end{array}$ & 14 Apr 1967 & $12: 36$ & 280 & $5: 5$ & .6853 & 95 & 1 & 11.05 & $\therefore 5$ & 85.52 & $\begin{array}{l}2.34 \\
.638\end{array}$ & $\begin{array}{r}.52 \\
.146\end{array}$ & .019 & .06 & .67 & $\begin{array}{l}.02 \\
.007\end{array}$ & $\begin{array}{l}\text { ii } \\
\text { A } 4 t\end{array}$ & $\begin{array}{r}100.00 \\
.901\end{array}$ & $\begin{array}{l}\text { MoLi } \\
\text { GFF? }\end{array}$ \\
\hline
\end{tabular}

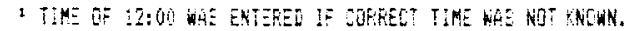

BOHTOERE:

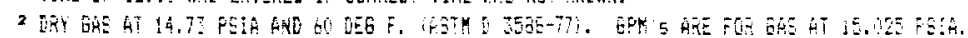

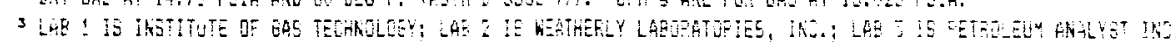


This is cholut 1.

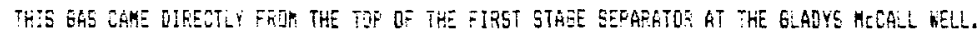

\begin{tabular}{|c|c|c|c|c|c|c|c|c|c|c|c|c|c|c|c|c|c|c|c|c|}
\hline $\begin{array}{c}\text { REORD } \\
\text { No. }\end{array}$ & $\begin{array}{l}\text { NUFEERS } \\
\text { IN FECORE }\end{array}$ & DHTE & TINE: & $\begin{array}{c}\text { iEMF, } \\
F \text {, }\end{array}$ & $\begin{array}{l}\text { FRESS, } \\
\text { PSIA }\end{array}$ & $\begin{array}{c}\text { ERAGIIYZ } \\
A I F=1\end{array}$ & $\begin{array}{l}\text { GRISS HEATING } \\
\text { VALLEE, BTUIEF }\end{array}$ & $\begin{array}{c}\angle A A^{3} \\
k 0 .\end{array}$ & 502 & $k 2$ & c! & 2 & 3 & $\$ \vdots 4$ & nit & $i c 5$ & $r: 25$ & 06 & TOTA: & \\
\hline$==$ & $==:=z$ & =:=ez=z=z=s & $z= \pm==$ & $===$ & $===$ & $====$ & $==z=$ & $====$ & $== \pm=$ & $== \pm x=$ & $==:=:$ & $=:=: 2$ & $=:== \pm$ & :=:=s & $=:= \pm=$ & $=z=z=$ & $=z= \pm=$ & $=:=z=$ & $=z= \pm=$ & \\
\hline $\begin{array}{l}13 \\
13\end{array}$ & $\begin{array}{r}1-17 \\
: E-25\end{array}$ & 14 Apr 1987 & $12: 40$ & 280 & 515 & $.68 ? 9$ & 933 & 1 & 10.97 & .5 & 85.73 & $\begin{array}{l}2.28 \\
.22 \%\end{array}$ & $\begin{array}{l}.50 \\
.140\end{array}$ & $\begin{array}{l}.08 \\
.027\end{array}$ & .077 & $\begin{array}{l}.03 \\
.011\end{array}$ & $\begin{array}{l}.02 \\
.007\end{array}$ & $\begin{array}{r}.07 \\
.229\end{array}$ & $\begin{array}{r}100.09 \\
.659\end{array}$ & 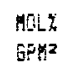 \\
\hline $\begin{array}{l}14 \\
14\end{array}$ & $\begin{array}{l}1-17 \\
8-25\end{array}$ & 14 Ap: 1987 & $13: 35$ & 280 & 516 & .3858 & 932 & 1 & 11.19 & .23 & 85.49 & $\begin{array}{l}2.30 \\
.627\end{array}$ & $\begin{array}{r}.49 \\
.138\end{array}$ & $\begin{array}{r}.07 \\
.023\end{array}$ & $\begin{array}{l}.07 \\
.022\end{array}$ & $\begin{array}{r}.03 \\
.011\end{array}$ & $\begin{array}{r}.62 \\
.007\end{array}$ & $\begin{array}{l}.11 \\
.046\end{array}$ & $\begin{array}{r}100.00 \\
.875\end{array}$ & $\begin{array}{l}\text { Muz } \\
\text { GFy }\end{array}$ \\
\hline
\end{tabular}

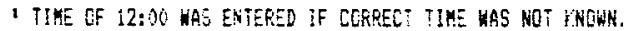

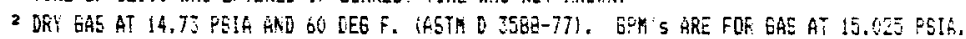

[GMITUP:AST]

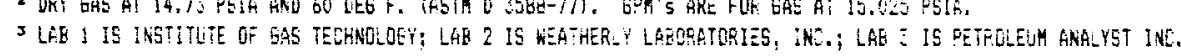


THIS IS CHOICE 2.

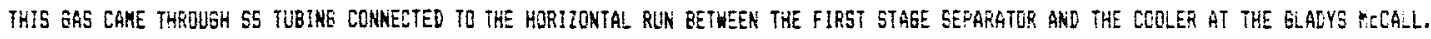

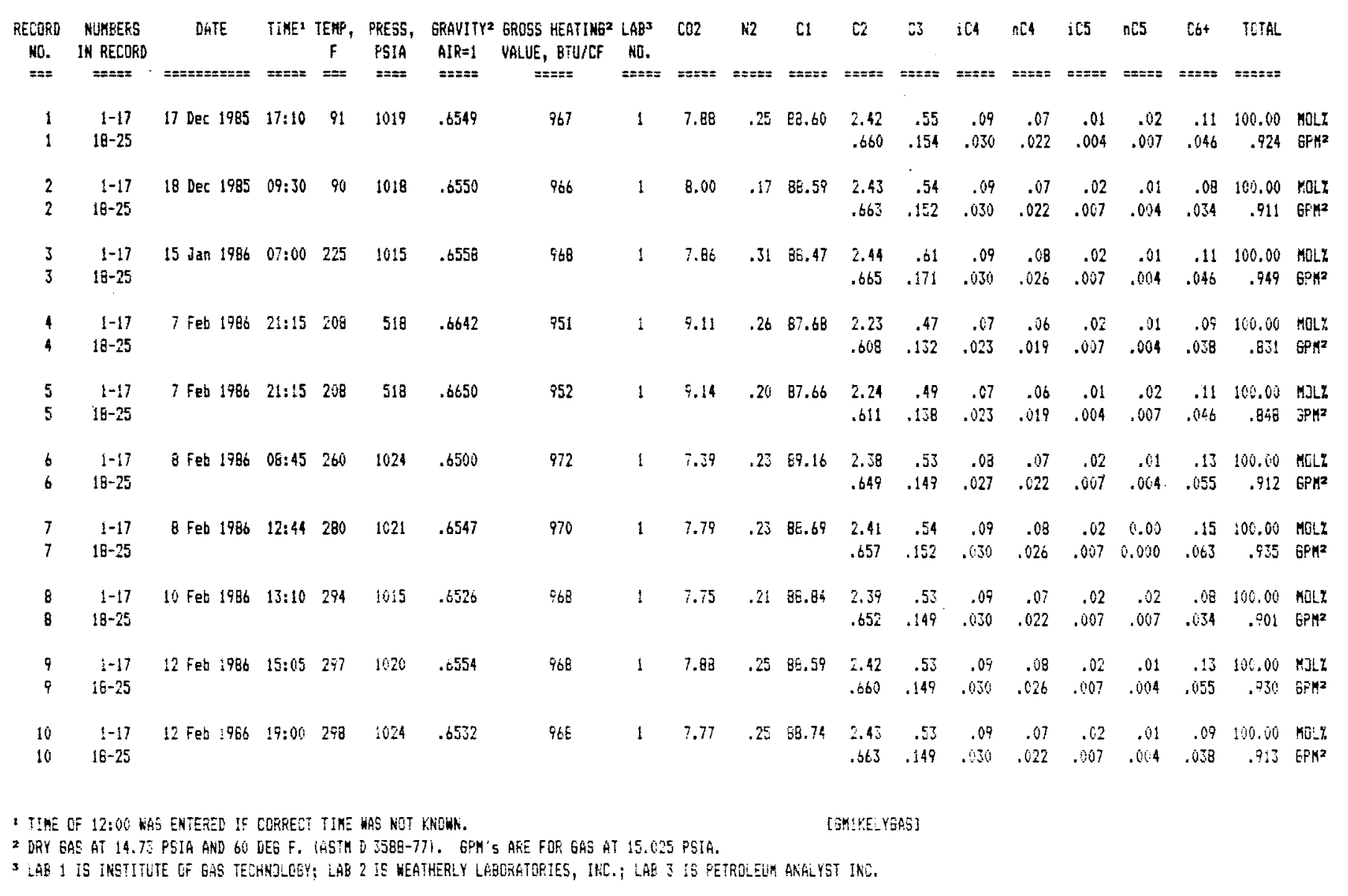


THIS 15 CHOICE 4.

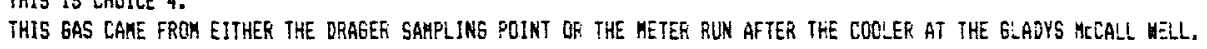

\begin{tabular}{|c|c|c|c|c|c|c|c|c|c|c|c|c|c|c|c|c|c|c|c|c|}
\hline $\begin{array}{l}\text { RECORD } \\
\text { NQ. } \\
\text { :=: }\end{array}$ & $\begin{array}{c}\text { NLLKEERS } \\
\text { IH RECORD } \\
=\neq=:=\end{array}$ & $\begin{array}{c}\text { DATE } \\
==:=\geq=2 z= \pm=\end{array}$ & $\begin{array}{l}\text { TIKE' } \\
==:= \pm\end{array}$ & $\begin{array}{l}\text { TEHP, } \\
F \\
==:\end{array}$ & $\begin{array}{l}\text { PRESS, } \\
\text { PSIA } \\
=\geq:=\end{array}$ & $\begin{array}{l}\text { BRAVITY2 } \\
\text { AIR=1 } \\
=:=:=\end{array}$ & $\begin{array}{l}\text { GEODS KEAIIJG } 2 \\
\text { VALUE, BTU/CF } \\
==2=\end{array}$ & $\begin{array}{l}\angle A B^{3} \\
N D . \\
== \pm==\end{array}$ & $=z= \pm=$ & $\begin{array}{l}\text { N2 } \\
=:==\end{array}$ & $=:==$ & $\begin{array}{c}C 2 \\
====\end{array}$ & $z= \pm s=$ & $\begin{array}{l}i C 4 \\
i=z=8\end{array}$ & $\begin{array}{l}n C 4 \\
=== \pm\end{array}$ & $== \pm=z$ & $\begin{array}{l}\mathrm{AC5} \\
=\geq= \pm\end{array}$ & $\begin{array}{l}C g t \\
=z=z\end{array}$ & $\begin{array}{l}\text { TOTAL } \\
===\leq=\end{array}$ & \\
\hline $\begin{array}{l}1 \\
1\end{array}$ & $\begin{array}{r}1-17 \\
18-25\end{array}$ & 8 Det 1983 & $12: 00$ & 97 & 500 & .6809 & 938 & 2 & 10.63 & .25 & 85.96 & $\begin{array}{l}2.34 \\
.638\end{array}$ & $\begin{array}{r}.52 \\
.146\end{array}$ & $\begin{array}{r}.09 \\
.030\end{array}$ & $\begin{array}{l}.07 \\
.022\end{array}$ & $\begin{array}{l}.02 \\
.007\end{array}$ & $\begin{array}{l}.01 \\
.004\end{array}$ & $\begin{array}{c}.11 \\
.046\end{array}$ & $\begin{array}{r}100.60 \\
.894\end{array}$ & \\
\hline $\begin{array}{l}2 \\
2\end{array}$ & $\begin{array}{r}1-17 \\
18-25\end{array}$ & 28 Oct 1983 & $12: 00$ & 275 & 515 & .7136 & 997 & 2 & 10.31 & .24 & 84.85 & $\begin{array}{l}2.31 \\
.630\end{array}$ & $\begin{array}{r}.51 \\
.143\end{array}$ & $\begin{array}{r}.09 \\
.030\end{array}$ & $\begin{array}{l}.08 \\
.026\end{array}$ & $\begin{array}{l}.02 \\
.007\end{array}$ & $\begin{array}{r}.01 \\
.004\end{array}$ & $\begin{array}{l}1.58 \\
.663\end{array}$ & $\begin{array}{r}100.00 \\
1.502\end{array}$ & \\
\hline $\begin{array}{l}3 \\
3\end{array}$ & $\begin{array}{r}1-17 \\
18-25\end{array}$ & $14 \operatorname{Jan}: 984$ & $12: 00$ & 227 & 769 & .6728 & 9.65 & 2 & 9.09 & .25 & 87.14 & $\begin{array}{l}2.41 \\
.657\end{array}$ & $\begin{array}{r}.55 \\
. .54\end{array}$ & .035 & $\begin{array}{l}.08 \\
.026\end{array}$ & .02 & .011 & $\begin{array}{l}.35 \\
.147\end{array}$ & $\begin{array}{r}100.00 \\
1.028\end{array}$ & \\
\hline $\begin{array}{l}4 \\
4\end{array}$ & $\begin{array}{r}1-17 \\
18-25\end{array}$ & 18 yan 1984 & $14: 00$ & 100 & 765 & .6560 & 1012 & 2 & 6.80 & .26 & 88.76 & $\begin{array}{l}2.44 \\
.665\end{array}$ & $\begin{array}{r}.55 \\
.154\end{array}$ & .010 & $\begin{array}{l}.05 \\
.02 t\end{array}$ & $\begin{array}{l}.03 \\
.011\end{array}$ & $\begin{array}{r}.02 \\
.607\end{array}$ & $\begin{array}{r}.86 \\
.403\end{array}$ & $\begin{array}{r}100.00 \\
1.300\end{array}$ & \\
\hline $\begin{array}{l}5 \\
5\end{array}$ & $\begin{array}{r}1-17 \\
18-25\end{array}$ & $24 \mathrm{Jan} 1984$ & $12: 00$ & 110 & 1015 & .6599 & 973 & 2 & 7.89 & .26 & 88.35 & $\begin{array}{l}2.48 \\
.676\end{array}$ & $\begin{array}{r}.57 \\
. \therefore 60\end{array}$ & $\begin{array}{r}.10 \\
.033\end{array}$ & $\begin{array}{r}.09 \\
.029\end{array}$ & $\begin{array}{r}.02 \\
.007\end{array}$ & .01 & $\begin{array}{r}.23 \\
.098\end{array}$ & $\begin{array}{r}100.00 \\
1.066\end{array}$ & \\
\hline $\begin{array}{l}6 \\
6\end{array}$ & $\begin{array}{r}1-17 \\
18-25\end{array}$ & $26 \mathrm{Jan} 1984$ & $12: 00$ & 100 & 1021 & .6559 & 970 & 2 & 7.81 & $.2 \mathrm{~s}$ & 88.52 & $\begin{array}{l}2.48 \\
.676\end{array}$ & $\begin{array}{r}.57 \\
.160\end{array}$ & .00 & $\begin{array}{r}.09 \\
.027\end{array}$ & $\begin{array}{r}.03 \\
.011\end{array}$ & .01 & $\begin{array}{l}.13 \\
.055\end{array}$ & $\begin{array}{r}100.00 \\
.968\end{array}$ & \\
\hline $\begin{array}{l}7 \\
7\end{array}$ & $\begin{array}{l}1-17 \\
18-25\end{array}$ & 27 dan 1984 & $12: 00$ & 245 & 1016 & .6561 & 970 & 2 & 7.83 & .27 & 88.51 & $\begin{array}{l}2.47 \\
.673\end{array}$ & $\begin{array}{r}.56 \\
.157\end{array}$ & .033 & .08 & $\begin{array}{r}.02 \\
.007\end{array}$ & .01 & $\begin{array}{r}.15 \\
.063\end{array}$ & $\begin{array}{r}100.00 \\
.964\end{array}$ & \\
\hline $\begin{array}{l}8 \\
8\end{array}$ & $\begin{array}{r}1-17 \\
19-25\end{array}$ & 7 Feb 1964 & $12: 00$ & 88 & 1015 & . .561 & 971 & 2 & 7.77 & .28 & 88.54 & $\begin{array}{l}2.47 \\
.673\end{array}$ & $\begin{array}{r}.56 \\
.157\end{array}$ & $\begin{array}{r}.10 \\
.0133\end{array}$ & $\begin{array}{r}.08 \\
.076\end{array}$ & $\begin{array}{r}.02 \\
.007\end{array}$ & .01 & $\begin{array}{r}.17 \\
.077\end{array}$ & $\begin{array}{r}190.00 \\
.972\end{array}$ & \\
\hline $\begin{array}{l}9 \\
9\end{array}$ & $\begin{array}{r}1-17 \\
18-25\end{array}$ & 7 Feb 1984 & $12: 00$ & 93 & $10: 5$ & .6530 & 979 & 2 & 7.29 & .27 & 28.95 & $\begin{array}{l}2.48 \\
.676\end{array}$ & $\begin{array}{r}.57 \\
.160\end{array}$ & $\begin{array}{r}.10 \\
.053\end{array}$ & $\begin{array}{r}.03 \\
.026\end{array}$ & .02 & $\begin{array}{r}.02 \\
.007\end{array}$ & .022 & $\begin{array}{r}100.00 \\
1.002\end{array}$ & \\
\hline $\begin{array}{l}10 \\
10\end{array}$ & $\begin{array}{r}1-17 \\
\pm \mathrm{G}-25\end{array}$ & $29 \mathrm{Fet} 1984$ & $11: 90$ & 89 & 324 & .7021 & 918 & 2 & 12.74 & .24 & 83.92 & $\begin{array}{l}0.25 \\
.613\end{array}$ & $\begin{array}{r}.49 \\
.238\end{array}$ & $\begin{array}{r}.08 \\
.027\end{array}$ & $\begin{array}{r}.07 \\
.022\end{array}$ & .02 & .01 & $\begin{array}{r}.18 \\
.075\end{array}$ & $\begin{array}{r}100.00 \\
.867\end{array}$ & \\
\hline $\begin{array}{l}11 \\
11\end{array}$ & $\begin{array}{r}1-17 \\
18-25\end{array}$ & 3 Har 1984 & $10: 00$ & 92 & 419 & .6911 & 930 & 2 & 11.61 & .24 & 85.03 & $\begin{array}{l}2.27 \\
.619\end{array}$ & $\begin{array}{r}.50 \\
\therefore 40\end{array}$ & $\begin{array}{r}.0 E \\
.027\end{array}$ & $\begin{array}{r}.07 \\
.022\end{array}$ & $\begin{array}{l}.02 \\
.007\end{array}$ & .011 & $\begin{array}{l}.17 \\
.01\end{array}$ & $\begin{array}{r}.00 .00 \\
.89 !\end{array}$ & \\
\hline $\begin{array}{l}12 \\
12\end{array}$ & $\begin{array}{r}1-17 \\
18-25\end{array}$ & ¿ Jun 1984 & $12: 00$ & 102 & 1605 & . 6595 & 567 & 2 & 8. \pm 5 & .27 & $8 E .20$ & $\begin{array}{l}2.44 \\
.065\end{array}$ & $\begin{array}{r}.55 \\
.157\end{array}$ & .60 & $\begin{array}{r}.08 \\
.026\end{array}$ & .03 & .087 & $\begin{array}{r}.15 \\
.063\end{array}$ & $\begin{array}{r}100.00 \\
.963\end{array}$ & \\
\hline
\end{tabular}

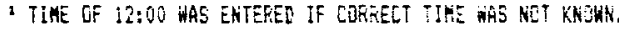

[GKIKETRänj]

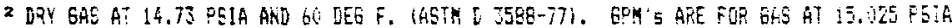

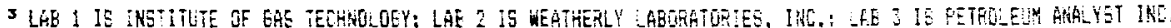


THIS IS CHOLCE 4.

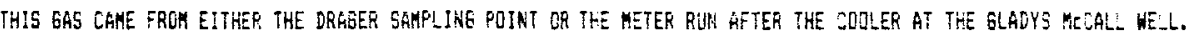

\begin{tabular}{|c|c|c|c|c|c|c|c|c|c|c|c|c|c|c|c|c|c|c|c|c|}
\hline $\begin{array}{l}\text { RECORD } \\
\text { KO. }\end{array}$ & $\begin{array}{l}\text { NUMAEERS } \\
\text { IN RECORD }\end{array}$ & DATE & TIME' & $\begin{array}{l}\text { TENF, } \\
\text { F }\end{array}$ & $\begin{array}{l}\text { FFESS, } \\
\text { PSIA }\end{array}$ & $\begin{array}{l}\text { GRPVITY } \\
\text { AIR }=1\end{array}$ & $\begin{array}{l}\text { GFRES HEGTING } \\
\text { VALUE, BTULCF }\end{array}$ & $\begin{array}{l}\angle A B^{3} \\
H J^{\prime}\end{array}$ & {$[32$} & $\mathrm{k} 2$ & ci & 2 & 03 & $i C A$ & $\mathrm{BCA}$ & ic5 & $\mathrm{nCS}$ & Cot & TUTAL & \\
\hline$== \pm$ & 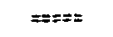 & 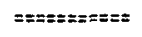 & $=:=:=$ & $===$ & $==\pi$ & $== \pm=$ & $=z==$ & $=: z=$ & $=====$ & $=:=:=$ & $==z==$ & $=z==$ & $====8$ & $== \pm==$ & $==z=$ & $=x=z$ & $=x= \pm$ & $z=z=$ & $y===8$ & \\
\hline $\begin{array}{l}13 \\
13\end{array}$ & $\begin{array}{r}1-17 \\
18-25\end{array}$ & 29 Jun 1984 & 5060 & $7 \mathrm{~B}$ & 945 & .6532 & 906 & 2 & 7.82 & .26 & 88.66 & $\begin{array}{l}2.45 \\
.069\end{array}$ & $\begin{array}{l}.56 \\
.157\end{array}$ & $\begin{array}{l}.10 \\
.033\end{array}$ & $\begin{array}{r}.08 \\
.026\end{array}$ & .02 & .01 & $\begin{array}{l}.04 \\
.017\end{array}$ & $\begin{array}{r}100.00 \\
.912\end{array}$ & $\begin{array}{l}\mathrm{MOLX} \\
\mathrm{GOH}^{5} \mathrm{H}^{2}\end{array}$ \\
\hline $\begin{array}{l}14 \\
14\end{array}$ & $\begin{array}{r}!-17 \\
18-25\end{array}$ & 4 Jun 1984 & $12: 00$ & 105 & 957 & .6535 & 966 & 2 & 5.14 & .27 & 88.23 & $\begin{array}{l}2.46 \\
.671\end{array}$ & $\begin{array}{r}.57 \\
.160\end{array}$ & .10 & $\begin{array}{r}.03 \\
.026\end{array}$ & $\begin{array}{r}.02 \\
.007\end{array}$ & $\begin{array}{r}.01 \\
.064\end{array}$ & .012 & $\begin{array}{r}006.00 \\
.951\end{array}$ & $\begin{array}{l}\text { MoL: } \\
\text { gith= }\end{array}$ \\
\hline $\begin{array}{l}15 \\
15\end{array}$ & $\begin{array}{r}1-17 \\
18-25\end{array}$ & $18 \mathrm{JuI} 1984$ & $14: 00$ & 97 & 1015 & .6552 & 970 & 2 & 7.80 & .25 & 88.59 & $\begin{array}{l}2.46 \\
.671\end{array}$ & $\begin{array}{r}.56 \\
.157\end{array}$ & $\begin{array}{r}.10 \\
.033\end{array}$ & $\begin{array}{r}.08 \\
.026\end{array}$ & $\begin{array}{r}.02 \\
.007\end{array}$ & $\begin{array}{r}.01 \\
.0044\end{array}$ & $\begin{array}{r}.03 \\
.055\end{array}$ & $\begin{array}{r}100.00 \\
.955\end{array}$ & $\begin{array}{l}\text { MGLX } \\
\text { GFM" }\end{array}$ \\
\hline $\begin{array}{l}16 \\
16\end{array}$ & $\begin{array}{r}1-17 \\
18-25\end{array}$ & 203011984 & $12: 00$ & 95 & 1015 & .6551 & 909 & 2 & 7.83 & .26 & 88.57 & $\begin{array}{l}2.46 \\
.671\end{array}$ & $\begin{array}{r}.56 \\
.57\end{array}$ & $\begin{array}{l}.10 \\
.033\end{array}$ & $\begin{array}{r}.08 \\
.026\end{array}$ & $\begin{array}{l}.02 \\
.007\end{array}$ & $\begin{array}{l}.01 \\
.004\end{array}$ & $\begin{array}{l}.11 \\
.046\end{array}$ & $\begin{array}{r}100.00 \\
.944\end{array}$ & $\begin{array}{l}\text { Mei. } \\
\text { EFF= }\end{array}$ \\
\hline $\begin{array}{l}17 \\
17\end{array}$ & $\begin{array}{r}1-17 \\
16-25\end{array}$ & 22 Jul 1984 & $12: 00$ & 101 & 995 & .6710 & 949 & 2 & 9.31 & .67 & 86.76 & $\begin{array}{l}2.45 \\
.668\end{array}$ & $\begin{array}{l}.53 \\
.149\end{array}$ & $\begin{array}{l}.09 \\
.830\end{array}$ & .07 & $\begin{array}{l}.02 \\
.007\end{array}$ & .014 & $\begin{array}{l}.13 \\
.055\end{array}$ & $\begin{array}{r}100.00 \\
.935\end{array}$ & $\begin{array}{l}\text { MJiL } \\
\text { GFH" }\end{array}$ \\
\hline $\begin{array}{l}18 \\
18\end{array}$ & $\begin{array}{r}1-17 \\
18-25\end{array}$ & 24 Jul 1984 & $12: 00$ & 94 & 1018 & .6560 & 570 & 2 & $7 . \theta^{2}$ & .27 & 82.53 & $\begin{array}{l}2.4 k \\
.671\end{array}$ & $\begin{array}{r}.56 \\
.557\end{array}$ &. .10 & $\begin{array}{l}.08 \\
.026\end{array}$ & $\begin{array}{r}.02 \\
.007\end{array}$ & $\begin{array}{l}.01 \\
.004\end{array}$ &. .15 & $\begin{array}{r}100.00 \\
.961\end{array}$ & $\begin{array}{l}\text { MOLY } \\
\text { GPHE }\end{array}$ \\
\hline $\begin{array}{l}19 \\
19\end{array}$ & $\begin{array}{r}1-17 \\
18-25\end{array}$ & 26 Jul 1984 & $12: 00$ & 82 & 1020 & .6560 & 909 & 2 & 7.88 & .26 & 86.50 & $\begin{array}{l}2.46 \\
.671\end{array}$ & $\begin{array}{r}.56 \\
.157\end{array}$ &. .10 & $\begin{array}{r}.08 \\
.026\end{array}$ & $\begin{array}{r}.02 \\
.007\end{array}$ & .01 & $\begin{array}{r}.13 \\
.055\end{array}$ & $\begin{array}{r}100.00 \\
.953\end{array}$ & $\begin{array}{l}\text { MjiY } \\
6 P H^{2}\end{array}$ \\
\hline $\begin{array}{l}20 \\
20\end{array}$ & $\begin{array}{r}1-17 \\
18-25\end{array}$ & 22 fug 1984 & $17: 00$ & 87 & $\$ 40$ & .6748 & 944 & 2 & 9.99 & .30 & 86.56 & $\begin{array}{l}2.33 \\
.635\end{array}$ & $\begin{array}{r}.52 \\
.146\end{array}$ & $\begin{array}{r}.09 \\
.036\end{array}$ & $\begin{array}{r}.67 \\
.022\end{array}$ & $\begin{array}{r}.02 \\
.007\end{array}$ & .01 & $\begin{array}{r}.11 \\
.646\end{array}$ & $\begin{array}{r}100.06 \\
.891\end{array}$ & $\begin{array}{l}\text { MOLY } \\
\text { GFH' }\end{array}$ \\
\hline $\begin{array}{l}21 \\
21\end{array}$ & $\begin{array}{r}1-17 \\
16-25\end{array}$ & 12 vet 1984 & $12: 10$ & 87 & 1034 & .6502 & 908 & 2 & 7.89 & .31 & $8 E .44$ & $\begin{array}{l}2.47 \\
.673\end{array}$ & $\begin{array}{r}.56 \\
.157\end{array}$ & .010 & $\begin{array}{r}.06 \\
.126\end{array}$ & $\begin{array}{r}.02 \\
.007\end{array}$ & .01 &. .12 & $\begin{array}{r}100.00 \\
.951\end{array}$ & $\begin{array}{l}m: 2 L \\
O P F K^{2}\end{array}$ \\
\hline $\begin{array}{l}22 \\
22\end{array}$ & $\begin{array}{r}i-17 \\
1 E-i j\end{array}$ & E ver 1954 & $12: 00$ & 210 & 1031 & .6550 & 976 & 2 & 7.54 & .28 & 83.71 & $\begin{array}{l}2.46 \\
.676\end{array}$ & $\begin{array}{l}.57 \\
.106\end{array}$ & .10 & $\begin{array}{l}.08 \\
.020\end{array}$ & $\begin{array}{l}.02 \\
.007\end{array}$ & .01 & $\begin{array}{r}.21 \\
.268\end{array}$ & $\begin{array}{r}100.00 \\
.994\end{array}$ & $\begin{array}{l}\$ 0 L: Z \\
\text { GeK" }\end{array}$ \\
\hline $\begin{array}{l}2 j \\
23\end{array}$ & $\begin{array}{r}1-17 \\
18-25\end{array}$ & 6 Det 1984 & $1: 00$ & 72 & 1010 & .6636 & 954 & 2 & 9.24 &.$\overline{2}$ & 37,34 & $\begin{array}{l}2.28 \\
.62\end{array}$ & .51 & .68 & $\begin{array}{r}.07 \\
.02 i\end{array}$ & .03 & .02 & .166 & $\begin{array}{r}110.00 \\
.900\end{array}$ & $\begin{array}{l}M U L Z \\
G^{P} H^{2}\end{array}$ \\
\hline $\begin{array}{l}24 \\
24\end{array}$ & $\begin{array}{r}1-17 \\
18-25\end{array}$ & 28 Feb 1985 & $12: 00$ & 80 & 1024 & .6566 & 971 & 2 & $7.8:$ & .27 & $8 E .45$ & $\begin{array}{l}2.49 \\
.279\end{array}$ & $\begin{array}{r}.59 \\
.166\end{array}$ &. .11 & $\begin{array}{r}.19 \\
.029\end{array}$ & .02 &. .67 & $\begin{array}{l}.14 \\
.657\end{array}$ & $\begin{array}{r}100.00 \\
.984\end{array}$ & $\begin{array}{l}\text { Mut } \\
\text { GP: }\end{array}$ \\
\hline
\end{tabular}

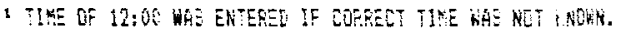

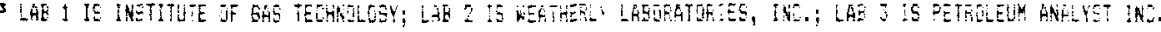


THIS IS CHOICE 4.

IHIS GRS CAHE FROH EITHER THE DRAJER SAMPLING PJINT OR THE KETER RUIN AFTER THE CDJLER AT THE GLADYS RELALL HELL.

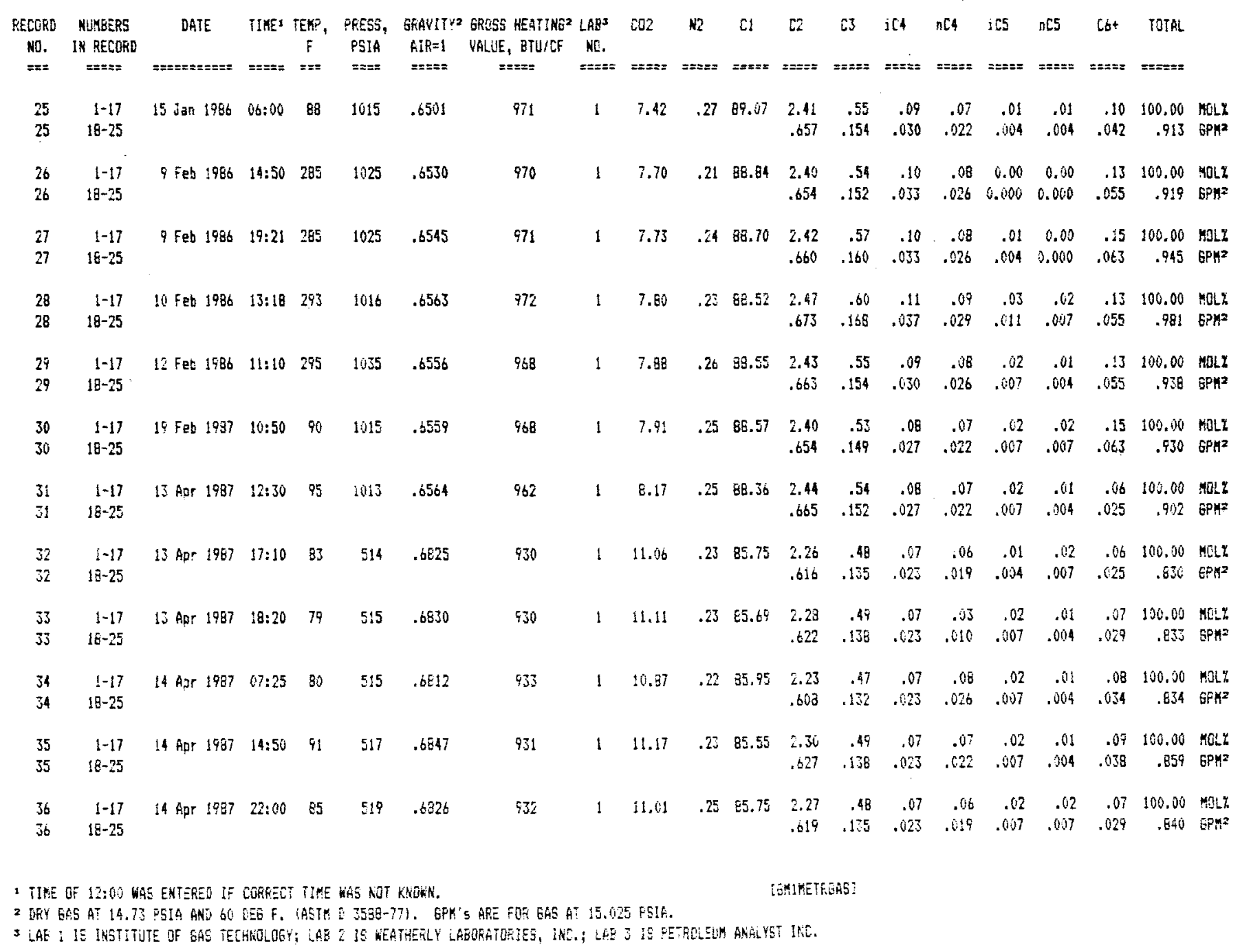


IHIS IS CHOICE 4.

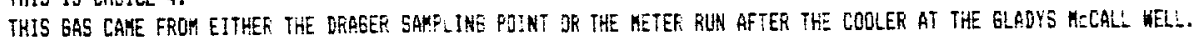

\begin{tabular}{|c|c|c|c|c|c|c|c|c|c|c|c|c|c|c|c|c|c|c|c|c|}
\hline $\begin{array}{l}\text { RECORD } \\
\text { NO. } \\
===\end{array}$ & $\begin{array}{l}\text { NUKEERS } \\
\text { IN RECDRD } \\
===32\end{array}$ & :=:z=:=:=:= & $\begin{array}{l}\text { TIKE" } \\
====\end{array}$ & $\begin{array}{l}\text { TEMP, } \\
\text { F } \\
===\end{array}$ & $\begin{array}{l}\text { PRESS, } \\
\text { PSIA } \\
= \pm==\end{array}$ & $\begin{array}{l}\text { GRAVITY2 } \\
\text { AIR }=1 \\
=====\end{array}$ & $\begin{array}{l}\text { GQRSS HEATING2 } \\
\text { WELLE, BTU/CF } \\
==:=\end{array}$ & $\begin{array}{l}\text { LABS } \\
\text { NQ. } \\
====\end{array}$ & $== \pm=$ & $z= \pm=$ & $== \pm==$ & $== \pm=$ & $=z= \pm=$ & $==z= \pm$ & $=2=:=$ & $==-=$ & $== \pm=$ & Cat & TOTAL & \\
\hline $\begin{array}{l}37 \\
37\end{array}$ & $\begin{array}{r}1-17 \\
18-25\end{array}$ & 15 Apr 1987 & $06: 25$ & 73 & 515 & .6827 & 431 & 1 & 11.09 & .22 & 85.70 & $\begin{array}{l}2.29 \\
.624\end{array}$ & $\begin{array}{r}.49 \\
.138\end{array}$ & .07 & .06 & $\begin{array}{r}0.00 \\
0.000\end{array}$ & $\begin{array}{l}0.00 \\
0.000\end{array}$ & $\begin{array}{r}.08 \\
.034\end{array}$ & $\begin{array}{r}100.00 \\
.338\end{array}$ & $\begin{array}{l}\text { MOLL } \\
\text { GPK2 }\end{array}$ \\
\hline $\begin{array}{l}38 \\
38\end{array}$ & $\begin{array}{r}1-17 \\
18-25\end{array}$ & $20 \mathrm{Apr} 1987$ & $16: 50$ & 78 & 1015 & .6554 & 963 & 1 & 8.07 & .25 & 88.47 & $\begin{array}{l}2.42 \\
.666\end{array}$ & $\begin{array}{r}.54 \\
.152\end{array}$ & $\begin{array}{r}.08 \\
.027\end{array}$ & $\begin{array}{l}.08 \\
.026\end{array}$ & $\begin{array}{l}.02 \\
.0107\end{array}$ & $\begin{array}{l}.02 \\
.007\end{array}$ & $\begin{array}{l}.05 \\
.021\end{array}$ & $\begin{array}{r}100.00 \\
.900\end{array}$ & $\begin{array}{l}\text { ROLL } \\
\text { GPY }\end{array}$ \\
\hline $\begin{array}{l}39 \\
39\end{array}$ & $\begin{array}{r}1-17 \\
18-25\end{array}$ & 27 Afr 1987 & $09: 45$ & 160 & 1020 & .6561 & 904 & 1 & 8.09 & .24 & 88.42 & $\begin{array}{l}2.44 \\
.665\end{array}$ & $\begin{array}{r}.55 \\
.154\end{array}$ & $\begin{array}{r}.08 \\
.027\end{array}$ & $\begin{array}{l}.07 \\
.022\end{array}$ & .02 & $\begin{array}{l}.02 \\
.067\end{array}$ & $\begin{array}{r}.07 \\
.029\end{array}$ & $\begin{array}{r}100.00 \\
.913\end{array}$ & $\begin{array}{l}\text { MOLI } \\
\text { GF }\end{array}$ \\
\hline
\end{tabular}

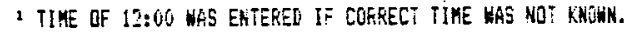

IEMMETKGAS

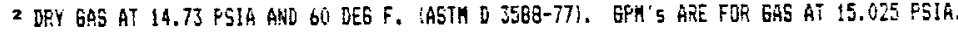

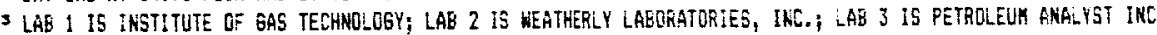


THIS IS CHOICE 5 .

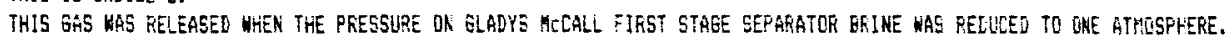

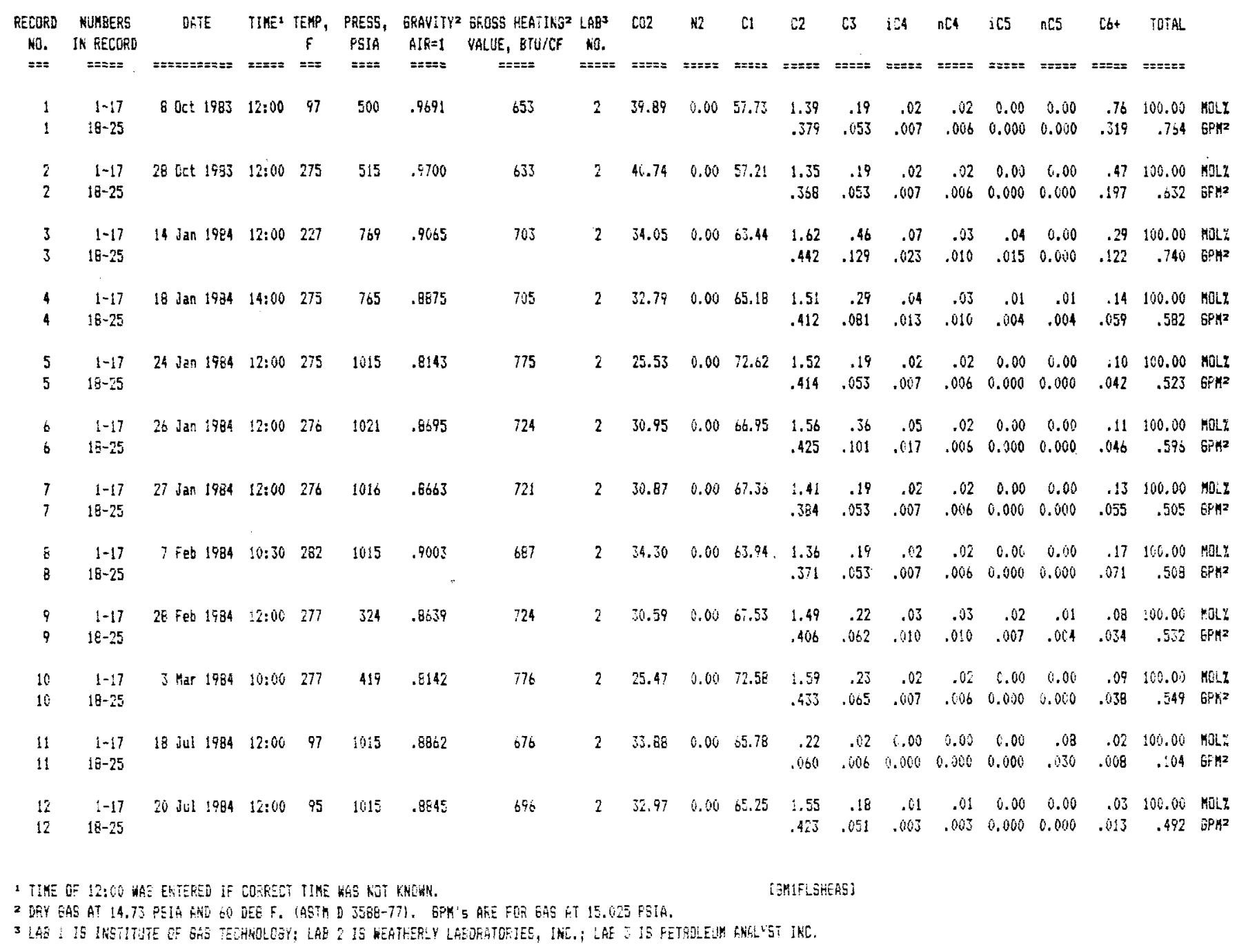


IHIS IS CHDICE 5 .

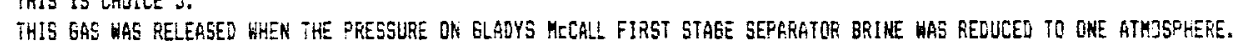

\begin{tabular}{|c|c|c|c|c|c|c|c|c|c|c|c|c|c|c|c|c|c|c|c|c|}
\hline $\begin{array}{l}\text { RECDRD } \\
\text { No. } \\
== \pm\end{array}$ & $\begin{array}{c}\text { NUABEERS } \\
\text { IN RECORD } \\
=z=z\end{array}$ & 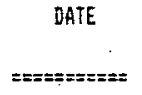 & IIME: & $\begin{array}{l}\text { TEMP, } \\
F \\
===\end{array}$ & $\begin{array}{l}\text { PRESS, } \\
\text { PSIA } \\
===\end{array}$ & $\begin{array}{l}\text { GRAVITY2 } \\
\text { ALR=1 } \\
====x\end{array}$ & $\begin{array}{l}\text { GRDSS HEATIHG } \\
\text { VALUE, BTUICF } \\
===-\end{array}$ & $\begin{array}{l}\mathrm{LAB}^{3} \\
\text { NO. } \\
=x=:=\end{array}$ & $=z= \pm=$ & $====$ & $=z= \pm=$ & $== \pm=$ & $== \pm=z$ & $t= \pm==$ & $z=z=$ & $== \pm=$ & $== \pm=$ & $== \pm=$ & TOTAL & \\
\hline $\begin{array}{l}13 \\
13\end{array}$ & $\begin{array}{r}1-17 \\
18-25\end{array}$ & $24 \mathrm{JuI} 1984$ & $12: 00$ & 94 & 1018 & .9022 & 679 & 2 & 34.76 & 0.00 & 03.66 & $\begin{array}{l}1.29 \\
.352\end{array}$ & $\begin{array}{r}.16 \\
.045\end{array}$ & $\begin{array}{l}.01 \\
.003\end{array}$ & .02 & $\begin{array}{l}0.00 \\
0.060\end{array}$ & $\begin{array}{r}.01 \\
.0144\end{array}$ & $\begin{array}{l}.09 \\
.038\end{array}$ & $\begin{array}{r}100.00 \\
.448\end{array}$ & $\begin{array}{l}\text { MOLL } \\
\text { GFH }\end{array}$ \\
\hline $\begin{array}{l}14 \\
14\end{array}$ & $\begin{array}{r}1-17 \\
18-25\end{array}$ & 263411984 & $12: 00$ & 82 & 1020 & . 8849 & 708 & 2 & 32.53 & 0.00 & 65.60 & $\begin{array}{l}1.39 \\
.379\end{array}$ & $\begin{array}{r}.20 \\
.056\end{array}$ & $\begin{array}{r}.02 \\
.007\end{array}$ & $\begin{array}{l}.02 \\
.006\end{array}$ & $\begin{array}{l}.03 \\
.011\end{array}$ & $\begin{array}{r}.01 \\
.004\end{array}$ & $\begin{array}{r}.26 \\
.0 E 4\end{array}$ & $\begin{array}{r}100,00 \\
.547\end{array}$ & $\begin{array}{l}\text { MOLI } \\
\text { GPHE }\end{array}$ \\
\hline $\begin{array}{l}15 \\
15\end{array}$ & $\begin{array}{r}1-17 \\
16-25\end{array}$ & i Fet 1986 & $21: 10$ & 208 & 518 & .8560 & 727 & $!$ & 29.99 & 0.00 & 68.37 & $\begin{array}{l}1.36 \\
.371\end{array}$ & $\begin{array}{r}.17 \\
.048\end{array}$ & $\begin{array}{r}.01 \\
.005\end{array}$ & $\begin{array}{l}.01 \\
.005\end{array}$ & $\begin{array}{r}.01 \\
.004\end{array}$ & $\begin{array}{l}0.00 \\
0.000\end{array}$ & $\begin{array}{r}.08 \\
.034\end{array}$ & $\begin{array}{r}100.00 \\
.462\end{array}$ & $\begin{array}{l}K 0 L I \\
G P H^{2}\end{array}$ \\
\hline $\begin{array}{l}16 \\
16\end{array}$ & $\begin{array}{r}1-17 \\
18-25\end{array}$ & $8 \mathrm{Feb} 1986$ & $08: 54$ & 264 & 103: & .8416 & 743 & 1 & 23.47 & 0.03 & 69.85 & $\begin{array}{l}1.30 \\
.376\end{array}$ & $\begin{array}{r}.18 \\
.051\end{array}$ & $\begin{array}{r}.02 \\
.007\end{array}$ & $\begin{array}{r}.01 \\
.003\end{array}$ & $\begin{array}{r}0.00 \\
0.000\end{array}$ & $\begin{array}{r}0.00 \\
0.000\end{array}$ & $\begin{array}{l}.09 \\
.038\end{array}$ & $\begin{array}{r}100.00 \\
.474\end{array}$ & $\begin{array}{l}\text { MOLY } \\
\text { GPH" }\end{array}$ \\
\hline $\begin{array}{l}17 \\
17\end{array}$ & $\begin{array}{r}1-17 \\
18-25\end{array}$ & B Fed 1986 & $12: 40$ & 280 & 1023 & .8471 & 738 & 1 & 28.99 & 0.00 & 69.31 & $\begin{array}{l}1.38 \\
.376\end{array}$ & $\begin{array}{r}.18 \\
.05 !\end{array}$ & $\begin{array}{r}.02 \\
.007\end{array}$ & $\begin{array}{l}.02 \\
.0066\end{array}$ & $\begin{array}{r}0.00 \\
0.000\end{array}$ & $\begin{array}{l}0.00 \\
0.000\end{array}$ & $\begin{array}{r}.10 \\
.042\end{array}$ & $\begin{array}{r}100.00 \\
.482\end{array}$ & $\begin{array}{l}\text { MOL! } \\
\text { GEH }\end{array}$ \\
\hline $\begin{array}{l}18 \\
18\end{array}$ & $\begin{array}{r}1-17 \\
18-25\end{array}$ & 10 Feb 1986 & $13: 25$ & 295 & 1017 & .7941 & 794 & 1 & 23.50 & 0.00 & 74.69 & $\begin{array}{l}1.49 \\
.406\end{array}$ & $\begin{array}{r}.20 \\
.056\end{array}$ & .02 & $\begin{array}{r}.02 \\
.006\end{array}$ & .01 & $\begin{array}{r}0.00 \\
0.000\end{array}$ & $\begin{array}{r}.07 \\
.029\end{array}$ & $\begin{array}{r}100.00 \\
.509\end{array}$ & $\begin{array}{l}\text { MOLL } \\
\text { BS }{ }^{2}\end{array}$ \\
\hline $\begin{array}{l}19 \\
19\end{array}$ & $\begin{array}{r}1-17 \\
18-25\end{array}$ & $10 \mathrm{Fel} 1986$ & $16: 00$ & 296 & 1014 & .8088 & 779 & 1 & 25.00 & 0.00 & 73.20 & $\begin{array}{l}1.47 \\
.401\end{array}$ & $\begin{array}{r}.20 \\
.056\end{array}$ & $\begin{array}{l}.02 \\
.007\end{array}$ & $\begin{array}{r}.02 \\
.006\end{array}$ & $\begin{array}{r}0.00 \\
0.600\end{array}$ & $\begin{array}{r}0.00 \\
0.000\end{array}$ & $\begin{array}{r}.09 \\
.038\end{array}$ & $\begin{array}{r}100.00 \\
.500\end{array}$ & $\begin{array}{l}\text { KJiY } \\
\text { GEMZ }\end{array}$ \\
\hline $\begin{array}{l}20 \\
20\end{array}$ & $\begin{array}{r}1-17 \\
18-25\end{array}$ & 11 Feb 1986 & $10: 34$ & 306 & 1020 & .9380 & 750 & 1 & 27.98 & 0.00 & 70.27 & $\begin{array}{l}1.40 \\
.382\end{array}$ & $\begin{array}{r}.19 \\
.053\end{array}$ & $\begin{array}{l}.02 \\
.007\end{array}$ & $\begin{array}{r}.012 \\
.006\end{array}$ & $\begin{array}{l}0.00 \\
0.000\end{array}$ & $\begin{array}{l}0.00 \\
0.000\end{array}$ & $\begin{array}{l}.12 \\
.050\end{array}$ & $\begin{array}{r}100.00 \\
.498\end{array}$ & $\begin{array}{l}\text { MOLK } \\
\text { GPME }\end{array}$ \\
\hline $\begin{array}{l}21 \\
21\end{array}$ & $\begin{array}{r}1-17 \\
1 E-25\end{array}$ & 11 fet 1986 & $11: 14$ & 289 & 1022 & .8185 & 770 & 1 & 25.98 & 0.00 & 72.25 & $\begin{array}{l}1.43 \\
.390\end{array}$ & $\begin{array}{r}.19 \\
.053\end{array}$ & $\begin{array}{l}.02 \\
.007\end{array}$ & $\begin{array}{r}.02 \\
.006\end{array}$ & $\begin{array}{l}0.00 \\
0.000\end{array}$ & $\begin{array}{r}0.00 \\
0.000\end{array}$ & $\begin{array}{r}.11 \\
.046\end{array}$ & $\begin{array}{r}100.00 \\
.502\end{array}$ & $\begin{array}{l}\text { RaLY } \\
\text { SPHY }\end{array}$ \\
\hline $\begin{array}{l}22 \\
22\end{array}$ & $\begin{array}{r}1-17 \\
18-25\end{array}$ & if Feb 148 b & $11: 38$ & 291 & 1019 & .9174 & 771 & 1 & 25.87 & 0.00 & 72.36 & $\begin{array}{l}\therefore .43 \\
.390\end{array}$ & $\begin{array}{r}.19 \\
.153\end{array}$ & $\begin{array}{l}.02 \\
.007\end{array}$ & $\begin{array}{r}.02 \\
.0066\end{array}$ & $\begin{array}{l}0.00 \\
0.600\end{array}$ & $\begin{array}{r}8.00 \\
0.600\end{array}$ & .11 & $\begin{array}{r}100.00 \\
.502\end{array}$ & $\begin{array}{l}\text { MELL } \\
\text { GPHE }\end{array}$ \\
\hline $\begin{array}{l}23 \\
23\end{array}$ & $\begin{array}{r}1-17 \\
1 \bar{E}-25\end{array}$ & U1 ret 1980 & $12: 24$ & 294 & 1020 & .8191 & 769 & 1 & 26.94 & 0.00 & 72.19 & $\begin{array}{l}1.43 \\
.390\end{array}$ & $\begin{array}{l}.19 \\
.05 ?\end{array}$ & .02 & $\begin{array}{l}.02 \\
.006\end{array}$ & $\begin{array}{l}0.00 \\
0.000\end{array}$ & $\begin{array}{l}0.60 \\
0.600\end{array}$ & $\begin{array}{l}.11 \\
.046\end{array}$ & $\begin{array}{r}100.00 \\
.532\end{array}$ & $\begin{array}{l}\text { KüL h̆ } \\
\text { GPM" }\end{array}$ \\
\hline $\begin{array}{l}24 \\
24\end{array}$ & $\begin{array}{r}1-17 \\
18-25\end{array}$ & 11 Fet 1986 & $14: 30$ & 302 & $\{(118$ & .8316 & 757 & 1 & 27.31 & 0.00 & 70.92 & $\begin{array}{l}1.41 \\
.384\end{array}$ & $\begin{array}{r}.20 \\
.656\end{array}$ & $\begin{array}{l}.02 \\
.007\end{array}$ & $\begin{array}{r}.02 \\
.066\end{array}$ & $\begin{array}{l}0.001 \\
0.000\end{array}$ & $\begin{array}{l}0.60 \\
0.000\end{array}$ & $\begin{array}{l}.12 \\
.050\end{array}$ & $\begin{array}{r}100.00 \\
.504\end{array}$ & $\begin{array}{l}\text { MELL } \\
6: K=2\end{array}$ \\
\hline
\end{tabular}

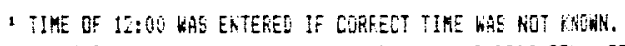

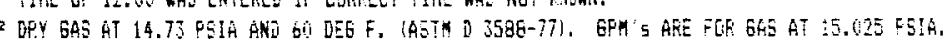

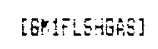

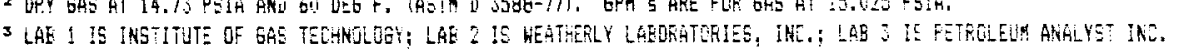


THIS IS CHOICE 5.

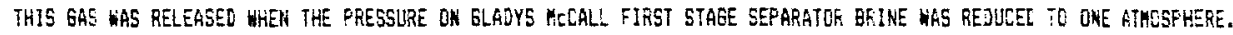

\begin{tabular}{|c|c|c|c|c|c|c|c|c|c|c|c|c|c|c|c|c|c|c|c|c|}
\hline $\begin{array}{l}\text { RECORD } \\
\text { NO. } \\
==\end{array}$ & $\begin{array}{l}\text { NUKGERS } \\
\text { IN RECORD } \\
=====\end{array}$ & $\begin{array}{c}\text { DATE } \\
===:======\end{array}$ & $\begin{array}{l}\text { TIME } \\
====\end{array}$ & $\begin{array}{c}\text { TEMP, } \\
F \\
==\end{array}$ & $\begin{array}{c}\text { PRESS, } \\
\text { PSIA } \\
=:==\end{array}$ & $\begin{array}{l}\text { GEAUITY2 } \\
\text { AIR=1 } \\
====\end{array}$ & $\begin{array}{l}\text { GROSS HEATING } \\
\text { VALUE, BTU/CF } \\
=== \pm\end{array}$ & $\begin{array}{l}\angle A \theta^{3} \\
N G . \\
==:==\end{array}$ & $\begin{array}{l}102 \\
=x==\end{array}$ & $\begin{array}{c}\mathrm{N} 2 \\
====\end{array}$ & $\begin{array}{l}31 \\
= \pm= \pm\end{array}$ & $\begin{array}{l}02 \\
=:=:=\end{array}$ & $= \pm=$ & $\begin{array}{l}\text { iCA } \\
==z=z\end{array}$ & $\begin{array}{l}n C 4 \\
====\end{array}$ & $\begin{array}{l}\mathrm{i} C 5 \\
=== \pm\end{array}$ & $\begin{array}{l}\text { nCS } \\
==:==\end{array}$ & $\begin{array}{l}\text { CSt } \\
== \pm==\end{array}$ & $=:= \pm=$ & \\
\hline $\begin{array}{l}25 \\
25\end{array}$ & $\begin{array}{r}1-17 \\
18-25\end{array}$ & 14 Apr 1967 & $10: 30$ & 280 & 515 & .8662 & 714 & 1 & 30.46 & $\therefore .02$ & 66.72 & $\begin{array}{l}1.45 \\
.395\end{array}$ & $\begin{array}{l}.21 \\
.055\end{array}$ & .02 & .02 & $\begin{array}{r}0.00 \\
0.000\end{array}$ & $\begin{array}{r}0.00 \\
0.000\end{array}$ & $\begin{array}{l}.10 \\
.047\end{array}$ & $\begin{array}{r}100.00 \\
.509\end{array}$ & $\begin{array}{l}M 0 L L \\
G P K^{2}\end{array}$ \\
\hline $\begin{array}{l}26 \\
26\end{array}$ & $\begin{array}{r}1-17 \\
19-25\end{array}$ & $\therefore 4$ Apr 1987 & $15: 20$ & 280 & 5.16 & .8501 & 734 & 1 & 28.90 & .66 & $\$ 8.56$ & $\begin{array}{l}1.49 \\
.406\end{array}$ & $\begin{array}{r}.22 \\
.062\end{array}$ & $\begin{array}{l}.02 \\
.007\end{array}$ & $\begin{array}{r}.02 \\
.006\end{array}$ & $\begin{array}{r}0.00 \\
0.060\end{array}$ & $\begin{array}{r}0.00 \\
0.900\end{array}$ & $\begin{array}{l}.11 \\
.046\end{array}$ & $\begin{array}{r}100.00 \\
.527\end{array}$ & $\begin{array}{l}\text { MOLY } \\
\text { SPH }\end{array}$ \\
\hline $\begin{array}{l}27 \\
27\end{array}$ & $\begin{array}{r}1-17 \\
1 E-25\end{array}$ & 14 Apr 1987 & $22: 30$ & 285 & 519 & $.343 \%$ & 740 & 1 & 28.36 & .50 & 69.35 & $\begin{array}{l}1.46 \\
.398\end{array}$ & $\begin{array}{r}.20 \\
.056\end{array}$ & $\begin{array}{r}.02 \\
.007\end{array}$ & $\begin{array}{r}.02 \\
.006\end{array}$ & $\begin{array}{r}0.00 \\
0.000\end{array}$ & $\begin{array}{r}0.10 \\
0.000\end{array}$ & .08 & $\begin{array}{r}100.00 \\
.501\end{array}$ & $\begin{array}{l}\text { MOLL } \\
\text { GPHYZ }\end{array}$ \\
\hline $\begin{array}{l}28 \\
28\end{array}$ & $\begin{array}{l}1-17 \\
16-25\end{array}$ & 15 Apr 1987 & $07: 10$ & 285 & 515 & .8537 & 728 & 1 & 25.34 & .70 & 65.20 & $\begin{array}{l}1.43 \\
.390\end{array}$ & $\begin{array}{r}.19 \\
.053\end{array}$ & $\begin{array}{r}.02 \\
.067\end{array}$ & $\begin{array}{l}.02 \\
.0066\end{array}$ & $\begin{array}{r}0.00 \\
0.000\end{array}$ & $\begin{array}{l}0.00 \\
0.060\end{array}$ & $\begin{array}{l}.10 \\
.042\end{array}$ & $\begin{array}{r}100.00 \\
\quad .498\end{array}$ & $\begin{array}{l}\text { MELL } \\
\text { GPH: }\end{array}$ \\
\hline $\begin{array}{l}29 \\
29\end{array}$ & $\begin{array}{r}1-17 \\
1 E-25\end{array}$ & 20 AP 1907 & $17: 40$ & 284 & 1015 & .8635 & 712 & 1 & 31.01 & .50 & 66.79 & $\begin{array}{l}1.38 \\
.376\end{array}$ & $\begin{array}{r}.22 \\
.062\end{array}$ & $\begin{array}{r}.01 \\
.003\end{array}$ & .01 & $\begin{array}{r}0.00 \\
0.000\end{array}$ & $\begin{array}{r}0.00 \\
0.000\end{array}$ & $\begin{array}{r}.08 \\
.034\end{array}$ & $\begin{array}{r}101.00 \\
.478\end{array}$ & $\begin{array}{l}\text { MDLI } \\
\text { GPFHZ }\end{array}$ \\
\hline
\end{tabular}

1 TIHE OF 12:00 WAS ENTERED IF COFRECT IIME HAS NOT KRDRN.

2 DRY GAS AT 14.73 FSIA AND 6! DEE F. LACTM D 358E-77), GPY'S ARE FOR GA5 AT 15.025 PSIA.

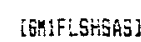

3 LAE 1 IS INSTITUTE OF GAS TECHNGLDOY; LAE 2 IS HEATHERLY LABOFATORIES, INC. LAE 3 :S PETHUE EUM ANALYST INR. 
iHIS IS CHUTCE 7 .

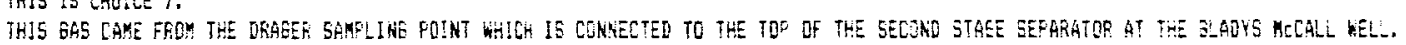

\begin{tabular}{|c|c|c|c|c|c|c|c|c|c|c|c|c|c|c|c|c|c|c|c|c|}
\hline $\begin{array}{l}\text { RECORD } \\
\text { NO. } \\
==\end{array}$ & $\begin{array}{l}\text { RUMEEFS } \\
\text { IN RECORD } \\
\text { =z=s: }\end{array}$ & $\begin{array}{c}\text { DATE } \\
\text { =z=:=:=z=s= }\end{array}$ & TIKE? & $\begin{array}{l}\text { TEMP, } \\
F \\
= \pm=\end{array}$ & $\begin{array}{l}\text { PFESS, } \\
\text { PSIA } \\
== \pm\end{array}$ & $\begin{array}{l}\text { GRAVITYY } \\
\text { AIR=1 } \\
==Z==\end{array}$ & $\begin{array}{l}\text { GROSS UEATING } \\
\text { WELUE, BTUICF } \\
\text { =:=:= }\end{array}$ & $\begin{array}{l}\text { LAES } \\
\text { HL. } \\
==:==\end{array}$ & $=:==$ & $== \pm=z$ & $== \pm=$ & $z==z=$ & $==x= \pm$ & $== \pm=z$ & $=z=z$ & $= \pm= \pm$ & $= \pm= \pm=$ & $\varepsilon_{6 t}$ & $==z==$ & \\
\hline 1 & $\begin{array}{r}1-17 \\
18-25\end{array}$ & 14 ian 1984 & $16: 00$ & $: 26$ & 340 & .7621 & 856 & 2 & 18.39 & .16 & 78.33 & $\begin{array}{l}1.81 \\
.493\end{array}$ & $\begin{array}{l}.28 \\
.079\end{array}$ & .03 & $\begin{array}{r}.03 \\
.010\end{array}$ & $\begin{array}{l}.03 \\
.011:\end{array}$ & $\begin{array}{l}.01 \\
.004\end{array}$ & $\begin{array}{r}.43 \\
.180\end{array}$ & $\begin{array}{r}100.00 \\
.787\end{array}$ & $\begin{array}{l}\text { KOLI } \\
\text { SPMY }\end{array}$ \\
\hline $\begin{array}{l}2 \\
2\end{array}$ & $\begin{array}{r}1-17 \\
: 8-25\end{array}$ & $24 \mathrm{Jan} 1984$ & $12: 00$ & 220 & 515 & .7053 & $9: 14$ & 2 & 13.54 & .89 & 83.74 & $\begin{array}{l}1.94 \\
.529\end{array}$ & $\begin{array}{r}.3 ! \\
.087\end{array}$ & .04 & .00 & $\begin{array}{r}0.00 \\
0.000\end{array}$ & $\begin{array}{r}0.00 \\
0.000\end{array}$ & $\begin{array}{r}.21 \\
.589\end{array}$ & $\begin{array}{r}100.00 \\
.727\end{array}$ & $\begin{array}{l}\text { MOLL } \\
\text { EPY }\end{array}$ \\
\hline $\begin{array}{l}3 \\
3\end{array}$ & $\begin{array}{r}1-17 \\
18-25\end{array}$ & $26 \tan 1984$ & $12: 00$ & 230 & 425 & .7275 & 834 & 2 & $: 5.73$ & . 18 & 81.61 & $\begin{array}{l}1.85 \\
.504\end{array}$ & $\begin{array}{r}.28 \\
.679\end{array}$ & .05 & $\begin{array}{r}.05 \\
.010\end{array}$ & $\begin{array}{r}0.00 \\
0.000\end{array}$ & $\begin{array}{r}.01 \\
.0014\end{array}$ & $\begin{array}{r}.26 \\
.117\end{array}$ & $\begin{array}{r}100.00 \\
.724\end{array}$ & $\begin{array}{l}\text { MOLL } \\
\text { GF }\end{array}$ \\
\hline $\begin{array}{l}4 \\
4\end{array}$ & $\begin{array}{r}1-17 \\
19-25\end{array}$ & 27 Jan 1984 & $12: 00$ & 250 & 319 & .7575 & 849 & 2 & 19.95 & .16 & 78.55 & $\begin{array}{l}1.75 \\
.477\end{array}$ & $\begin{array}{r}.26 \\
.073\end{array}$ & $\begin{array}{l}.03 \\
.010\end{array}$ & $\begin{array}{r}.02 \\
.006\end{array}$ & $\begin{array}{r}.01 \\
.004\end{array}$ & $\begin{array}{r}0.00 \\
0.000\end{array}$ & $\begin{array}{r}.27 \\
.113\end{array}$ & $\begin{array}{r}105.00 \\
.683\end{array}$ & $\begin{array}{l}\text { MOLZ } \\
\text { GFK' }\end{array}$ \\
\hline $\begin{array}{l}5 \\
5\end{array}$ & $\begin{array}{r}1-17 \\
1 E-25\end{array}$ & $7 \mathrm{Fet} 1984$ & $12: 30$ & 156 & 418 & .7244 & 801 & 2 & 15.67 & .12 & 81.88 & $\begin{array}{l}1.78 \\
.465\end{array}$ & $\begin{array}{r}.28 \\
.079\end{array}$ & $\begin{array}{l}.03 \\
.030\end{array}$ & .03 & $\begin{array}{r}0.00 \\
0.000\end{array}$ & $\begin{array}{l}0.00 \\
0.000\end{array}$ & $\begin{array}{r}.21 \\
.188\end{array}$ & $\begin{array}{r}106.00 \\
.672\end{array}$ & $\begin{array}{l}\mathrm{MDL} \% \\
\mathrm{BF} \mathrm{H}^{2}\end{array}$ \\
\hline $\begin{array}{l}6 \\
6\end{array}$ & $\begin{array}{r}1-17 \\
19-25\end{array}$ & 9 Feb 1954 & $12: 00$ & 252 & 315 & .7412 & 866 & 2 & 17.26 & .13 & 80.23 & $\begin{array}{l}1.74 \\
.474\end{array}$ & $\begin{array}{r}.26 \\
.073\end{array}$ & $\begin{array}{r}.03 \\
.010\end{array}$ & $\begin{array}{l}.02 \\
.006\end{array}$ & $\begin{array}{r}0.00 \\
0.000\end{array}$ & $\begin{array}{r}0.00 \\
0.000\end{array}$ & $\begin{array}{r}.28 \\
.117\end{array}$ & $\begin{array}{r}100.00 \\
.681\end{array}$ & $\begin{array}{l}\text { KuLL } \\
\text { GP: }\end{array}$ \\
\hline $\begin{array}{l}7 \\
7\end{array}$ & $\begin{array}{r}:-17 \\
18-25\end{array}$ & 18 Jui 1984 & 14:010 & 223 & 5.15 & .7633 & 905 & 2 & $: 3.40$ & .17 & 83.93 & $\begin{array}{l}1.91 \\
.521\end{array}$ & $\begin{array}{r}.31 \\
.067\end{array}$ & .03 & $\begin{array}{r}.03 \\
.010\end{array}$ & $\begin{array}{r}0.05 \\
0.060\end{array}$ & $\begin{array}{l}.02 \\
.007\end{array}$ & $\begin{array}{r}.18 \\
.675\end{array}$ & $\begin{array}{r}100.00 \\
.710\end{array}$ & $\begin{array}{l}\text { MaL\% } \\
\text { GPM" }\end{array}$ \\
\hline $\begin{array}{l}B \\
E\end{array}$ & $\begin{array}{r}1-17 \\
18-25\end{array}$ & 20 iul 3984 & $12: 00$ & 225 & 415 & .7252 & 875 & 2 & 15.98 & .17 & 81.54 & $\begin{array}{l}1.83 \\
.494\end{array}$ & $\begin{array}{r}.28 \\
.079\end{array}$ & .03 & $\begin{array}{r}.01 \\
.010\end{array}$ & $\begin{array}{r}0.00 \\
0.000\end{array}$ & $\begin{array}{r}0.00 \\
0.000\end{array}$ & $\begin{array}{r}.14 \\
.054\end{array}$ & $\begin{array}{r}100.00 \\
.656\end{array}$ & $\begin{array}{l}\text { MoL } \\
\text { Get }\end{array}$ \\
\hline 9 & $\begin{array}{r}1-17 \\
13-25\end{array}$ & 24 jul 1984 & $13: 00$ & 225 & 318 & .7698 & 847 & 2 & 19.63 & .32 & 77.60 & $\begin{array}{l}1.69 \\
.458\end{array}$ & $\begin{array}{r}.25 \\
.070\end{array}$ & $\begin{array}{l}.03 \\
.0110\end{array}$ & $\begin{array}{l}.03 \\
.010\end{array}$ & .01 & .01 & $\begin{array}{l}.44 \\
.185\end{array}$ & $\begin{array}{r}100.00 \\
.740\end{array}$ & $\begin{array}{l}\text { MoLL } \\
\text { operz }\end{array}$ \\
\hline $\begin{array}{l}10 \\
10\end{array}$ & $\begin{array}{r}1-17 \\
18-25\end{array}$ & 26 Ju: 1964 & $1=00$ & 267 & 269 & .7887 & 813 & 2 & 22.24 & .29 & 75.30 & $\begin{array}{l} \pm .63 \\
.444\end{array}$ & $\begin{array}{l}.23 \\
.065\end{array}$ & .62 & .005 & $\begin{array}{r}.01 \\
.304\end{array}$ & $\begin{array}{r}6.00 \\
0.000\end{array}$ & $\begin{array}{r}.26 \\
.109\end{array}$ & $\begin{array}{r}100.00 \\
.635\end{array}$ & $\begin{array}{l}\text { MLL } \\
\text { GPH }\end{array}$ \\
\hline $\begin{array}{l}11 \\
11\end{array}$ & $\begin{array}{r}1-17 \\
19-25\end{array}$ & 12 oct $: 984$ & $11: 46$ & 265 & $3: 4$ & .7839 & 237 & 2 & 21.47 & .17 & 75.60 & $\begin{array}{l}1.69 \\
.461\end{array}$ & $\begin{array}{r}.25 \\
.07 i\end{array}$ & .05 & .02 & $\begin{array}{r}0.50 \\
0.600\end{array}$ & $\begin{array}{r}6.00 \\
0.090\end{array}$ & $\begin{array}{l}.37 \\
.155\end{array}$ & $\begin{array}{r}190.00 \\
.703\end{array}$ & $\begin{array}{l}\text { MLL' } \\
8 F H^{2}\end{array}$ \\
\hline $\begin{array}{l}12 \\
12\end{array}$ & $\begin{array}{r}1-17 \\
18-25\end{array}$ & 6 jec 1984 & $22: 60$ & 28 & 563 & .70060 & $89:$ & 2 & 17.46 & $\therefore 9$ & $7 \% .29$ & $\begin{array}{l}. .74 \\
.474\end{array}$ & $\begin{array}{r}.27 \\
.076\end{array}$ & $\begin{array}{l}.03 \\
.010\end{array}$ & .010 & .02 & $\begin{array}{r}.03 \\
.011\end{array}$ & $\begin{array}{r}.54 \\
.394\end{array}$ & $\begin{array}{r}100.00 \\
.905\end{array}$ & $\begin{array}{l}\text { RiLL } \\
\text { EF }\end{array}$ \\
\hline
\end{tabular}

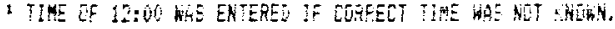


IHIS IS CHOICE 7

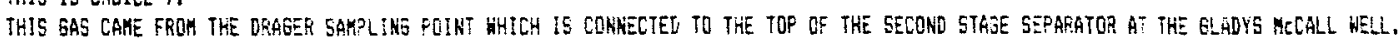

\begin{tabular}{|c|c|c|c|c|c|c|c|c|c|c|c|c|c|c|c|c|c|c|c|c|}
\hline $\begin{array}{l}\text { RECORD } \\
\text { NO. } \\
==-\end{array}$ & $\begin{array}{l}\text { RUUABERS } \\
\text { If RECGRD } \\
= \pm===\end{array}$ & $\begin{array}{c}\text { DHTE } \\
==:==:====\end{array}$ & $\begin{array}{l}\text { TINE' } \\
====\end{array}$ & $\begin{array}{l}\text { TEMF, } \\
F \\
= \pm=\end{array}$ & $\begin{array}{l}\text { PRES5, } \\
\text { PSIA } \\
===\end{array}$ & $\begin{array}{l}\text { ERAVITYZ } \\
\text { AIF=1 } \\
==:==\end{array}$ & $\begin{array}{l}\text { GROSS HEATING } \\
\text { VALUE, ETU/LF } \\
===:=\end{array}$ & $\begin{array}{l}\angle A B^{3} \\
\text { MO. } \\
== \pm=:\end{array}$ & $=z=8$ & $z=s=$ & $=z= \pm$ & $= \pm z=$ & $===:=$ & $\begin{array}{l}\mathrm{i} C 4 \\
=z=z\end{array}$ & $=s==$ & $\begin{array}{l}i C 5 \\
= \pm=8\end{array}$ & $\begin{array}{l}\text { nCS } \\
==-x=\end{array}$ & $=:=x=$ & :=:=:=x & \\
\hline $\begin{array}{l}13 \\
15\end{array}$ & $\begin{array}{r}1-17 \\
18-25\end{array}$ & 28 Fet 1985 & $12: 00$ & 245 & 365 & .7493 & 854 & 2 & 18.25 & .18 & 79.26 & $\begin{array}{l}1.78 \\
.485\end{array}$ &. .27 & $\begin{array}{l}.03 \\
.010\end{array}$ & $\begin{array}{l}.053 \\
.016\end{array}$ & $\begin{array}{r}0.00 \\
0.000\end{array}$ & $\begin{array}{r}0.00 \\
0.000\end{array}$ & .08 & $\begin{array}{r}106.00 \\
.665\end{array}$ & $\begin{array}{l}\text { MoL: } \\
\text { EPY? }\end{array}$ \\
\hline $\begin{array}{l}14 \\
14\end{array}$ & $\begin{array}{r}1-17 \\
18-25\end{array}$ & 17 Dec 1985 & $17: 20$ & 276 & 430 & .7260 & 875 & 1 & 16.00 & .17 & B..55 & $\begin{array}{l}1.81 \\
.493\end{array}$ & $\begin{array}{r}.28 \\
.079\end{array}$ & $\begin{array}{r}.03 \\
.010\end{array}$ & .03 & $\begin{array}{r}0.60 \\
0.000\end{array}$ & $\begin{array}{r}0.00 \\
0.000\end{array}$ & $\begin{array}{r}.13 \\
.055\end{array}$ & $\begin{array}{r}100.00 \\
.046\end{array}$ & $\begin{array}{l}\text { NOL\% } \\
\text { EPH }\end{array}$ \\
\hline $\begin{array}{l}15 \\
15\end{array}$ & $\begin{array}{r}t-17 \\
16-25\end{array}$ & te Get 1985 & $09: 44$ & 270 & 435 & .7264 & 875 & $!$ & 16.04 & .10 & 81.57 & $\begin{array}{l}1.81 \\
.493\end{array}$ & $\begin{array}{r}.27 \\
.076\end{array}$ & $\begin{array}{r}.03 \\
.010\end{array}$ & $\begin{array}{r}.03 \\
.010\end{array}$ & $\begin{array}{r}0.00 \\
0.000\end{array}$ & $\begin{array}{l}.02 \\
.007\end{array}$ & $\begin{array}{l}.13 \\
.055\end{array}$ & $\begin{array}{r}100.00 \\
. t 51\end{array}$ & $\begin{array}{l}\text { FLLZ } \\
\text { GPHZ }\end{array}$ \\
\hline $\begin{array}{l}16 \\
16\end{array}$ & $\begin{array}{r}1-17 \\
18-25\end{array}$ & 15 Jar: 1986 & $06: 15$ & 245 & 356 & . & 862 & 1 & 17.16 & .27 & 80.45 & $\begin{array}{l}1.68 \\
.458\end{array}$ & $\begin{array}{r}.34 \\
.095\end{array}$ & $\begin{array}{l}.02 \\
.007\end{array}$ & $\begin{array}{r}.02 \\
.006\end{array}$ & $\begin{array}{r}0.00 \\
0.060\end{array}$ & $\begin{array}{r}0.00 \\
0.000\end{array}$ & $\begin{array}{l}.12 \\
.650\end{array}$ & $\begin{array}{r}100.60 \\
.617\end{array}$ & $\begin{array}{l}\text { MOLI } \\
\text { EPY }\end{array}$ \\
\hline $\begin{array}{l}17 \\
17\end{array}$ & $\begin{array}{r}1-17 \\
18-25\end{array}$ & 10 Fet 1986 & $16: 30$ & 293 & 268 & 列.758 & 823 & 1 & 21.18 & .11 & 76.64 & $\begin{array}{l}1.60 \\
.436\end{array}$ & .23 & $\begin{array}{r}.02 \\
.007\end{array}$ & $\begin{array}{r}.02 \\
.006\end{array}$ & .011 & $\begin{array}{r}0.00 \\
0.000\end{array}$ & $\begin{array}{r}.19 \\
.080\end{array}$ & $\begin{array}{r}100.00 \\
.597\end{array}$ & $\begin{array}{l}\text { MOLL } \\
\text { GPY }\end{array}$ \\
\hline $\begin{array}{l}18 \\
18\end{array}$ & $\begin{array}{r}1-17 \\
18-25\end{array}$ & 11 Feb 1986 & $10: 22$ & 305 & 323 & .7548 & 844 & 1 & 19.02 & .15 & 78.66 & $\begin{array}{l}1.71 \\
.466\end{array}$ &. .26 & $\begin{array}{r}.03 \\
.010\end{array}$ & $\begin{array}{r}.03 \\
.010\end{array}$ & $\begin{array}{r}0.00 \\
0.000\end{array}$ & $\begin{array}{r}0.00 \\
0.000\end{array}$ & $\begin{array}{r}.14 \\
.059\end{array}$ & $\begin{array}{r}100.00 \\
.618\end{array}$ & $\begin{array}{l}\text { MoLI } \\
\text { gFitz }\end{array}$ \\
\hline $\begin{array}{l}19 \\
19\end{array}$ & $\begin{array}{r}1-17 \\
1 E-25\end{array}$ & $12 \mathrm{Feb}: 986$ & $: 2: 05$ & 295 & 324 & .7483 & 848 & 1 & 18.44 & .37 & 79.28 & $\begin{array}{l}1.70 \\
.465\end{array}$ & $\begin{array}{r}.24 \\
.067\end{array}$ & $\begin{array}{r}.03 \\
.010\end{array}$ & .02 & $\begin{array}{r}0.00 \\
0.000\end{array}$ & $\begin{array}{r}0.00 \\
0.000\end{array}$ & .12 & $\begin{array}{r}100.00 \\
.598\end{array}$ & $\begin{array}{l}\text { KeLL } \\
\text { GPH' }\end{array}$ \\
\hline $\begin{array}{l}20 \\
20\end{array}$ & $\begin{array}{r}1-17 \\
18-25\end{array}$ & $19 \mathrm{Feb} 19.87$ & $09: 40$ & 280 & 285 & .7694 & 828 & 1 & $20.5 \bar{z}$ & .16 & 77.22 & $\begin{array}{l}1.64 \\
.447\end{array}$ & $\begin{array}{r}.24 \\
.067\end{array}$ & $\begin{array}{l}.02 \\
.007\end{array}$ & .02 & $\begin{array}{r}.01 \\
.004\end{array}$ & $\begin{array}{r}0.00 \\
0.000\end{array}$ & .177 & $\begin{array}{r}100.00 \\
.603\end{array}$ & $\begin{array}{l}\text { Fol: } \\
\text { GPYZ }\end{array}$ \\
\hline $\begin{array}{l}21 \\
21\end{array}$ & $\begin{array}{r}1-17 \\
18-25\end{array}$ & i3 Apr 1987 & $09: 30$ & 276 & $4: 5$ & .7310 & 864 & 1 & 16.71 & .22 & 80.90 & $\begin{array}{l}1.81 \\
.493\end{array}$ & $\begin{array}{r}.26 \\
.073\end{array}$ & $\begin{array}{l}.02 \\
.007\end{array}$ & $\begin{array}{r}.01 \\
.003\end{array}$ & $\begin{array}{r}0.00 \\
0.606\end{array}$ & $\begin{array}{l}0.00 \\
0.000\end{array}$ & $\begin{array}{l}.07 \\
.029\end{array}$ & $\begin{array}{r}103.00 \\
.606\end{array}$ & $\begin{array}{l}\text { MoLL } \\
\text { SPFt }\end{array}$ \\
\hline $\begin{array}{l}22 \\
22\end{array}$ & $\begin{array}{r}1-17 \\
18-25\end{array}$ & 13 Apr 1987 & $16: 30$ & 260 & 409 & .7029 & $8 \div 9$ & 1 & $15.6 \hat{0}$ & .18 & 83.73 & $\begin{array}{l}2.01 \\
.548\end{array}$ & $\begin{array}{r}.35 \\
.398\end{array}$ & $\begin{array}{r}.04 \\
.013\end{array}$ & $\begin{array}{r}.00 ? \\
.310\end{array}$ & .01 & $\begin{array}{r}0.00 \\
0.000\end{array}$ & .05 & $\begin{array}{r}100.60 \\
.694\end{array}$ & $\begin{array}{l}\text { BjLL } \\
\text { GPF }\end{array}$ \\
\hline $\begin{array}{l}23 \\
23\end{array}$ & $\begin{array}{r}1-17 \\
16-25\end{array}$ & 15 App 1987 & $17: 40$ & 250 & 410 & .7065 & $E 9 ?$ & 1 & 12.89 & .19 & 33.35 & $\begin{array}{l}2.06 \\
.562\end{array}$ & $\begin{array}{r}.36 \\
.101\end{array}$ & $\begin{array}{r}.04 \\
.0 ! 3\end{array}$ & $\begin{array}{l}.04 \\
.0: 3\end{array}$ & $\begin{array}{r}0.00 \\
0.000\end{array}$ & $\begin{array}{r}0.00 \\
0.000\end{array}$ & $\begin{array}{l}.67 \\
.67\end{array}$ & $\begin{array}{r}100.05 \\
.718\end{array}$ & $\begin{array}{l}\text { MEL } \\
\text { GEY }\end{array}$ \\
\hline $\begin{array}{l}24 \\
24\end{array}$ & $\begin{array}{r}1-17 \\
18-25\end{array}$ & ¿4 Ápr 198? & $06: 50$ & 230 & 420 & .7019 & 905 & 1 & 13.30 & .21 & 83.94 & $\begin{array}{l}2.08 \\
.567\end{array}$ & $\begin{array}{r}.3 \bar{E} \\
.67\end{array}$ & .04 & .05 & .01 & $\begin{array}{r}.01 \\
.004\end{array}$ & $\begin{array}{l}.02 \\
.034\end{array}$ & $\begin{array}{r}100.06 \\
.744\end{array}$ & $\begin{array}{l}\text { RQLY } \\
\text { GEF }\end{array}$ \\
\hline
\end{tabular}

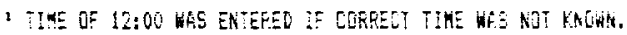

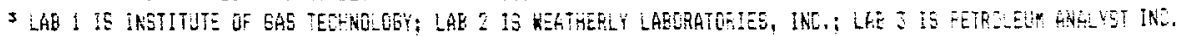


THIS IS CHOICE 7.

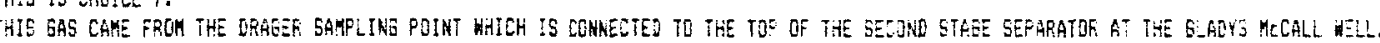

\begin{tabular}{|c|c|c|c|c|c|c|c|c|c|c|c|c|c|c|c|c|c|c|c|c|}
\hline $\begin{array}{l}\text { RECORD } \\
\text { NQ. } \\
==\end{array}$ & $\begin{array}{l}\text { NUMGEERS } \\
\text { IK RECORD } \\
====z\end{array}$ & $\begin{array}{c}\text { OATE } \\
=:=: x==:==:\end{array}$ & $\begin{array}{l}\text { IIME } 1 \\
\text { =:=:= }\end{array}$ & $\begin{array}{l}\text { TEMP, } \\
F \\
===\end{array}$ & $\begin{array}{l}\text { PFESS, } \\
\text { PSIA } \\
===\end{array}$ & $\begin{array}{l}\text { GRAVITYZ } \\
\text { AIR=1 } \\
=====\end{array}$ & $\begin{array}{l}\text { GROSS HEATING } \\
\text { VALUE, BTU/CF } \\
====\end{array}$ & $\begin{array}{l}\mathrm{LAB^{3 }} \\
\mathrm{NO} \\
===-\end{array}$ & $\mathrm{CO}$ & $\begin{array}{l}\mathrm{N} 2 \\
==2==\end{array}$ & Cl & $\mathrm{C}$ & $c i$ & iC4 & $5: C 4$ & $i[5$ & nes & $\mathrm{Cb}+$ & TOTAL & \\
\hline $\begin{array}{l}25 \\
25\end{array}$ & $\begin{array}{r}1-17 \\
28-25\end{array}$ & $14 \mathrm{Apr} 1987$ & $06: 30$ & $28 \mathrm{C}$ & 420 & .7036 & 904 & $\mathrm{i}$ & 13.43 & .19 & 83.71 & $\begin{array}{l}2.08 \\
.567\end{array}$ & $\begin{array}{l}.38 \\
.107\end{array}$ & $\begin{array}{r}.05 \\
.017\end{array}$ & $\begin{array}{l}.05 \\
.016\end{array}$ & $\begin{array}{l}.01 \\
.004\end{array}$ & $\begin{array}{l}0.00 \\
0.000\end{array}$ & .040 & $\begin{array}{r}100.00 \\
.752\end{array}$ & $\begin{array}{l}F 0 ! Z \\
\text { GPHY }\end{array}$ \\
\hline $\begin{array}{l}26 \\
26\end{array}$ & $\begin{array}{r}1-17 \\
1 \bar{E}-25\end{array}$ & 14 Aor $\$ 987$ & $14: 00$ & 270 & 442 & .7036 & 9014 & 1 & 3.44 & .19 & 83.66 & $\begin{array}{l}2.13 \\
.581\end{array}$ & $\begin{array}{r}.39 \\
.209\end{array}$ & $\begin{array}{r}.04 \\
.013\end{array}$ & .04 & $\begin{array}{r}.01 \\
.004\end{array}$ & $.0 !$ & .09 & $\begin{array}{r}100.00 \\
.762\end{array}$ & $\begin{array}{l}\text { HOLY } \\
\text { GPM? }\end{array}$ \\
\hline $\begin{array}{l}27 \\
27\end{array}$ & $\begin{array}{r}-17 \\
18-25\end{array}$ & 14 Apr 1987 & $26: 00$ & 280 & 449 & .6967 & 912 & 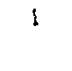 & 12.70 & .20 & 84.35 & $\begin{array}{l}. .15 \\
.586\end{array}$ & $\begin{array}{r}.4 ! \\
\therefore 15\end{array}$ & $\begin{array}{l}.05 \\
.057\end{array}$ & .05 & $\begin{array}{r}0.00 \\
0.000\end{array}$ & $\begin{array}{r}0.06 \\
0.000\end{array}$ & $\begin{array}{r}.09 \\
.038\end{array}$ & $\begin{array}{r}100.00 \\
.772\end{array}$ & $\begin{array}{l}\text { MOLL } \\
\text { GFM }\end{array}$ \\
\hline $\begin{array}{l}28 \\
28\end{array}$ & $\begin{array}{r}1-17 \\
18-25\end{array}$ & 20 Aar 1987 & $17: 20$ & 250 & 450 & .7198 & 891 & 1 & 15.36 & .17 & 82.16 & $\begin{array}{l}1.84 \\
.502\end{array}$ & $\begin{array}{r}.30 \\
.034\end{array}$ & $\begin{array}{r}.03 \\
.010\end{array}$ & .03 & $\begin{array}{l}.03 \\
.011\end{array}$ & $\begin{array}{r}0.00 \\
0.000\end{array}$ & $\begin{array}{l}.03 \\
.034\end{array}$ & $\begin{array}{r}100.02 \\
.650\end{array}$ & $\begin{array}{l}M C L L \\
\text { BFH }\end{array}$ \\
\hline $\begin{array}{l}29 \\
29\end{array}$ & $\begin{array}{r}1-17 \\
18-25\end{array}$ & 27 Apr 1987 & 10: $: 4$ & 274 & 46.3 & .7193 & 879 & $i$ & 15.41 & .17 & 82.15 & $\begin{array}{l}1.86 \\
.507\end{array}$ & $\begin{array}{r}.28 \\
.079\end{array}$ & $\begin{array}{r}.02 \\
.007\end{array}$ & .02 & $\begin{array}{r}0.00 \\
0,300\end{array}$ & $\begin{array}{l}0.00 \\
0.000\end{array}$ & $\begin{array}{r}.09 \\
.058\end{array}$ & $\begin{array}{r}190.00 \\
.637\end{array}$ & $\begin{array}{l}\text { MOLZ } \\
\text { SPR }\end{array}$ \\
\hline
\end{tabular}

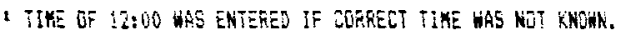

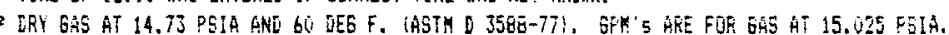

[ER2DKAEOAST

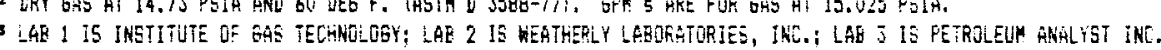


THIS IS CHOICE 8.

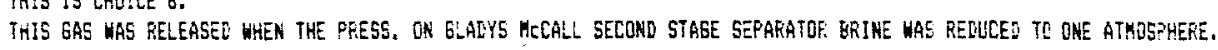

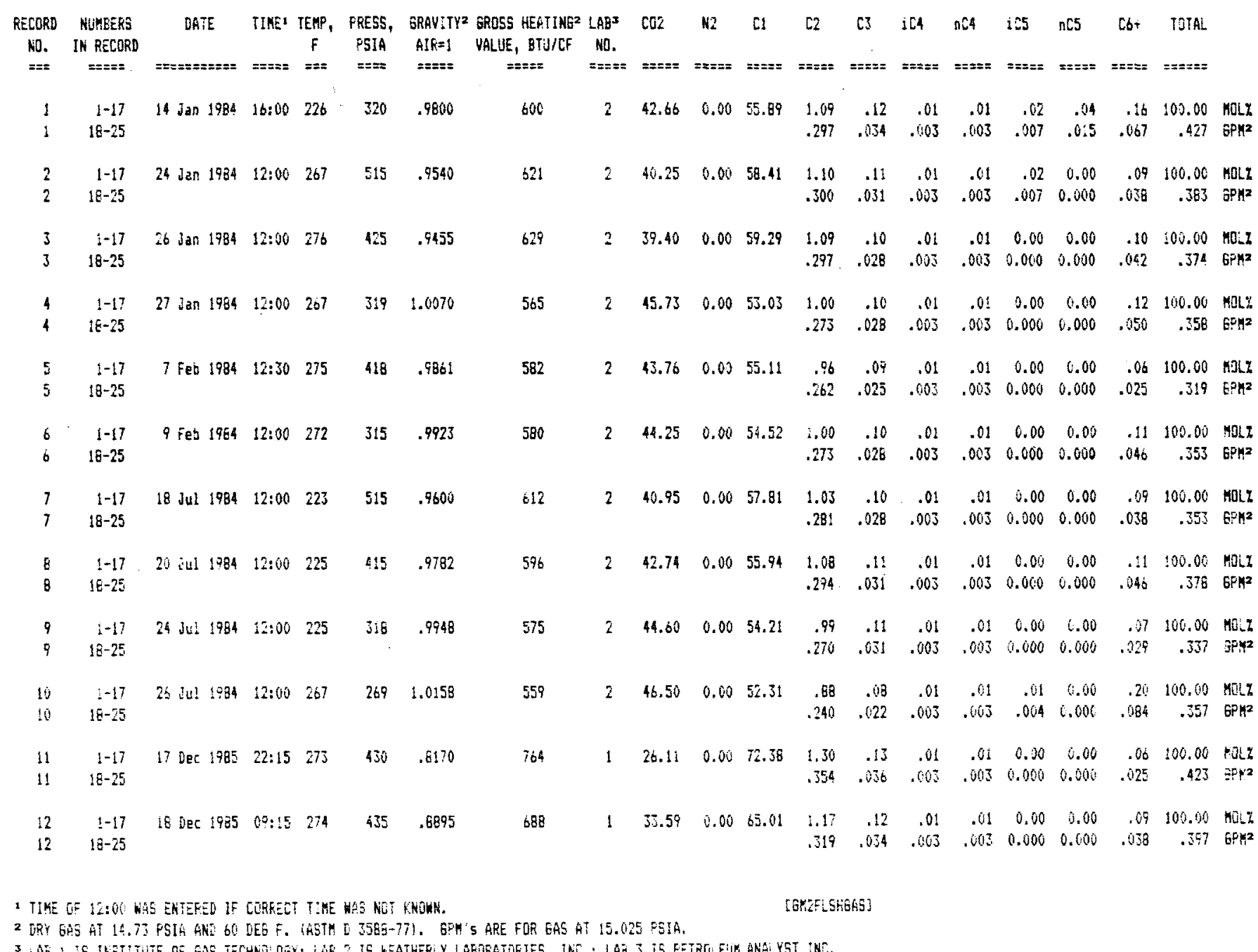

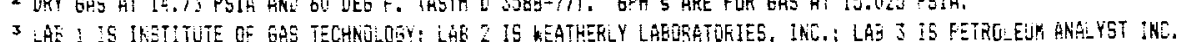


THIS is CHOLCE 8.

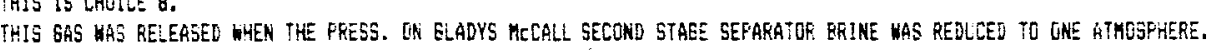

\begin{tabular}{|c|c|c|c|c|c|c|c|c|c|c|c|c|c|c|c|c|c|c|c|c|}
\hline $\begin{array}{l}\text { RECOKI } \\
\text { NO. } \\
===\end{array}$ & $\begin{array}{l}\text { NHIMBERS } \\
\text { IN RECORO } \\
=====\end{array}$ & $\begin{array}{c}\text { OATE } \\
\text { =:=:=:=:=:= }\end{array}$ & $\begin{array}{l}\text { TiKE } \\
\text { =:=E= }\end{array}$ & $\begin{array}{l}\text { TEMP, } \\
F \\
===\end{array}$ & $\begin{array}{l}\text { PRESS, } \\
\text { PS1A } \\
====\end{array}$ & $\begin{array}{l}\text { GRAVIm: } \\
\text { AiR=1 } \\
:====\end{array}$ & $\begin{array}{l}\text { GROSE HEATING2 } \\
\text { VALLE, BTU/LF } \\
\text { =E==: }\end{array}$ & $\begin{array}{l}\text { LAG3 } \\
\text { NO. } \\
====\end{array}$ & $\begin{array}{l}002 \\
====\end{array}$ & $\begin{array}{l}N_{2} \\
== \pm=\end{array}$ & $\begin{array}{l}01 \\
== \pm==\end{array}$ & $\begin{array}{c}c 2 \\
===\end{array}$ & $\begin{array}{c}c 3 \\
=2==\end{array}$ & $=\leq s=z$ & =z=:= & $\begin{array}{l}\text { iCs } \\
\text { =s:=s }\end{array}$ & $====z$ & $\begin{array}{l}\text { Cot } \\
=====\end{array}$ & $\begin{array}{l}\text { TOTAL } \\
\text { ==:== }\end{array}$ & \\
\hline $\begin{array}{l}13 \\
13\end{array}$ & $\begin{array}{r}1-17 \\
18-25\end{array}$ & 15 Jan 1986 & $09: 30$ & 245 & 356 & .9162 & 661 & 1 & 36.33 & 6.00 & $6 . .37$ & $\begin{array}{l}1.06 \\
.289\end{array}$ & $\begin{array}{l}.10 \\
.028\end{array}$ & $\begin{array}{r}0.00 \\
0.000\end{array}$ & .003 & $\begin{array}{r}0.00 \\
0.000\end{array}$ & $\begin{array}{r}0.00 \\
0.000\end{array}$ & $\begin{array}{l}.13 \\
.055\end{array}$ & $\begin{array}{r}100.00 \\
.575\end{array}$ & $\begin{array}{l}M D L Y \\
G F M^{2}\end{array}$ \\
\hline $\begin{array}{l}14 \\
14\end{array}$ & $\begin{array}{r}1-17 \\
1 E-25\end{array}$ & $19 \mathrm{Fes} 198 ?$ & $11: 00$ & 280 & 285 & .9268 & 637 & 1 & 37.39 & .81 & 60.25 & $\begin{array}{l}. .05 \\
.286\end{array}$ & $\begin{array}{r}.10 \\
.628\end{array}$ & $\begin{array}{l}.01 \\
.003\end{array}$ & $\begin{array}{r}0.00 \\
0.000\end{array}$ & $\begin{array}{r}0.00 \\
0.000\end{array}$ & $\begin{array}{r}0.00 \\
0.000\end{array}$ & $\begin{array}{r}.08 \\
.034\end{array}$ & $\begin{array}{r}99.69 \\
.351\end{array}$ & $\begin{array}{l}\text { MOLL } \\
\text { GPM }\end{array}$ \\
\hline $\begin{array}{l}15 \\
15\end{array}$ & $\begin{array}{r}1-17 \\
1 E-25\end{array}$ & 13 Apr 1987 & $10: 50$ & 276 & 416 & .9444 & 622 & 1 & 38.97 & .97 & 58.81 & $\begin{array}{l}1.06 \\
.289\end{array}$ & $\begin{array}{r}.10 \\
.028\end{array}$ & .01 & $\begin{array}{l}.01 \\
.003\end{array}$ & $\begin{array}{r}0.00 \\
0.000\end{array}$ & $\begin{array}{r}0.00 \\
0.000\end{array}$ & $\begin{array}{r}.07 \\
.029\end{array}$ & $\begin{array}{r}100.00 \\
. \quad 853\end{array}$ & $\begin{array}{l}\text { MOLL } \\
\text { SPH }\end{array}$ \\
\hline $\begin{array}{l}16 \\
16\end{array}$ & $\begin{array}{r}1-17 \\
18-25\end{array}$ & $13 \mathrm{Apr} 1987$ & $19: 00$ & 253 & 419 & .8937 & 679 & 1 & 33.59 & .96 & 63.95 & $\begin{array}{l}1.26 \\
.344\end{array}$ & $\begin{array}{r}.15 \\
.042\end{array}$ & .01 & $\begin{array}{l}.01 \\
.003\end{array}$ & $\begin{array}{r}0.20 \\
0.000\end{array}$ & $\begin{array}{r}0.00 \\
0.000\end{array}$ & $\begin{array}{r}.07 \\
.029\end{array}$ & $\begin{array}{r}100.60 \\
.422\end{array}$ & $\begin{array}{l}M R_{L} Z \\
G P K^{2}\end{array}$ \\
\hline $\begin{array}{l}17 \\
17\end{array}$ & $\begin{array}{r}1-17 \\
18-25\end{array}$ & 14 Apr 1987 & $09: 00$ & 280 & 420 & .8864 & 699 & 1 & 32.70 & 1.03 & 64.68 & $\begin{array}{l}1.31 \\
.357\end{array}$ & $\begin{array}{l}.16 \\
.045\end{array}$ & $\begin{array}{r}.01 \\
.0033\end{array}$ & .01 & $\begin{array}{r}0.00 \\
0.009\end{array}$ & $\begin{array}{r}0.00 \\
0.060\end{array}$ & $\begin{array}{r}.10 \\
.042\end{array}$ & $\begin{array}{r}100.00 \\
.451\end{array}$ & $\begin{array}{l}\text { MoLZ } \\
\text { GPY? }\end{array}$ \\
\hline $\begin{array}{l}18 \\
18\end{array}$ & $\begin{array}{r}{[-17} \\
18-25\end{array}$ & $14 \mathrm{Apr} 1987$ & $10: 00$ & 275 & 445 & $.844 ?$ & 735 & 1 & 26.56 & $.6 !$ & 69.12 & $\begin{array}{l}1.43 \\
.390\end{array}$ & .18 & $\begin{array}{r}.01 \\
.003\end{array}$ & $\begin{array}{l}.03 \\
.010\end{array}$ & $\begin{array}{r}0.60 \\
0.000\end{array}$ & $\begin{array}{r}0.00 \\
0.000\end{array}$ & $\begin{array}{l}.06 \\
.025\end{array}$ & $\begin{array}{r}100.00 \\
.479\end{array}$ & $\begin{array}{l}\text { MJLZ } \\
\text { GPHE }\end{array}$ \\
\hline $\begin{array}{l}19 \\
19\end{array}$ & $\begin{array}{r}1-17 \\
18-25\end{array}$ & 14 Ap: 1987 & $21: 15$ & 280 & 447 & .3301 & 749 & 1 & 27.01 & .78 & 70.52 & $\begin{array}{l}1.43 \\
.390\end{array}$ & .651 & .01 & .01 & $\begin{array}{r}0.00 \\
0.000\end{array}$ & $\begin{array}{r}0.00 \\
0.000\end{array}$ & .06 & $\begin{array}{r}100.00 \\
.472\end{array}$ & $\begin{array}{l}\text { KOLZZ } \\
\text { GPYZ }\end{array}$ \\
\hline $\begin{array}{l}20 \\
20\end{array}$ & $\begin{array}{r}1-17 \\
18-25\end{array}$ & 27 Apr 1987 & $10: 00$ & 274 & 463 & .9351 & 632 & 1 & 38.17 & .70 & 59.88 & $\begin{array}{l}1.08 \\
.294\end{array}$ & $\begin{array}{l}.11 \\
.031\end{array}$ & .01 & $\begin{array}{r}0.00 \\
0.000\end{array}$ & $\begin{array}{r}0.00 \\
0.000\end{array}$ & $\begin{array}{r}0.00 \\
0.600\end{array}$ & $\begin{array}{l}.05 \\
.021\end{array}$ & $\begin{array}{r}100,00 \\
.350\end{array}$ & $\begin{array}{l}\text { MaL: } \\
\text { BrFh }\end{array}$ \\
\hline & & & & & & & & & & & & & & & & & & & & \\
\hline
\end{tabular}


THIS ES CHOICE 9.

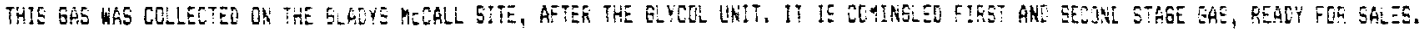

\begin{tabular}{|c|c|c|c|c|c|c|c|c|c|c|c|c|c|c|c|c|c|c|c|c|}
\hline $\begin{array}{l}\text { KEOURL } \\
\text { ND. } \\
===\end{array}$ & $\begin{array}{l}\text { NGHEERE } \\
\text { IN RECOKO } \\
=:==:\end{array}$ & $\begin{array}{c}\text { DAIE } \\
=:=s=s=s=8\end{array}$ & $\begin{array}{l}\text { TIME2 } \\
==:==\end{array}$ & $\begin{array}{l}\text { EEMP, } \\
F \\
===\end{array}$ & $\begin{array}{l}\text { PRESS, } \\
\text { PSIA } \\
====\end{array}$ & $\begin{array}{l}\text { GRRVITYZ } \\
\text { AIR=1 } \\
=====\end{array}$ & $\begin{array}{l}\text { GROSS HERTING? } \\
\text { VALLE, BTU/CF } \\
====\end{array}$ & $\begin{array}{l}\mathrm{AA9^{5 }} \\
\mathrm{NO} \\
====\end{array}$ & $\begin{array}{l}\mathrm{CO}: \\
=:==\end{array}$ & $\begin{array}{l}\mathrm{N2} \\
=\geq==\end{array}$ & $\begin{array}{l}01 \\
z=:=\end{array}$ & $\begin{array}{l}02 \\
==:=\end{array}$ & $=\geq \pm=2$ & $== \pm=$ & $\begin{array}{l}\pi 04 \\
: 2:=2\end{array}$ & $: \geq z=z$ & $n: 5$ & $\begin{array}{l}\text { Cot } \\
=2=2=\end{array}$ & TOTAL & \\
\hline $\begin{array}{l}1 \\
1\end{array}$ & $\begin{array}{r}1-17 \\
18-25\end{array}$ & 12 oct 1984 & $12: 42$ & 98 & 1015 & .6748 & $94 !$ & 2 & 16.15 & .26 & 8..52 & $\begin{array}{l}2.32 \\
.033\end{array}$ & $\begin{array}{r}.50 \\
.140\end{array}$ & . & $\begin{array}{r}.07 \\
.02\end{array}$ & .02 & $\begin{array}{r}.01 \\
.002\end{array}$ & $\begin{array}{r}.07 \\
.029\end{array}$ & $\begin{array}{r}100.00 \\
.663\end{array}$ & $\begin{array}{l}\text { MEL: } \\
\text { GFF }\end{array}$ \\
\hline $\begin{array}{l}2 \\
2\end{array}$ & $\begin{array}{r}1-17 \\
1 \mathrm{E}-25\end{array}$ & $25 \mathrm{Fek}: 1985$ & $12: 00$ & $6 ?$ & 1024 & .6676 & 955 & 2 & 9.15 & .77 & 87.32 & $\begin{array}{l}\therefore .39 \\
.652\end{array}$ & $\begin{array}{r}.54 \\
.152\end{array}$ & .10 & $\begin{array}{r}.08 \\
.020\end{array}$ & .02 & $\begin{array}{l}.02 \\
.00 ?\end{array}$ & $\begin{array}{r}.11 \\
.046\end{array}$ & $\begin{array}{r}100.00 \\
.633\end{array}$ & $\begin{array}{l}\text { sill: } \\
\text { of } x^{2}\end{array}$ \\
\hline 3 & $\begin{array}{r}1-: 7 \\
13-25\end{array}$ & LE Fe: IVES & $i z: 00$ & 12 & 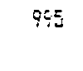 & .6077 & $95 \mathrm{E}$ & 2 & 9.20 & .26 & Bi.jo & $\begin{array}{l}2.39 \\
.652\end{array}$ & $\begin{array}{r}.53 \\
.549\end{array}$ & .69 & $\begin{array}{r}.09 \\
.029\end{array}$ & $\begin{array}{r}.02 \\
.097\end{array}$ & $\begin{array}{r}.61 \\
.604\end{array}$ &. .15 & $\begin{array}{r}100.50 \\
.933\end{array}$ & $\begin{array}{l}M D_{2} \\
\mathrm{SP} \mathrm{H}^{2}\end{array}$ \\
\hline $\begin{array}{l}4 \\
4\end{array}$ & $\begin{array}{r}1-17 \\
: 6-: 5\end{array}$ & 153231980 & $06: 55$ & 79 & 619 & .0510 & 952 & $!$ & 3.93 & .14 & 87.95 & $\begin{array}{l}2.29 \\
.624\end{array}$ & $\begin{array}{r}.51 \\
.143\end{array}$ & .08 & $\begin{array}{r}.06 \\
.019\end{array}$ & $\begin{array}{l}0.00 \\
6.000\end{array}$ & $\begin{array}{l}0.00 \\
0.000\end{array}$ & $\begin{array}{r}.04 \\
.017\end{array}$ & $\begin{array}{r}00.60 \\
.830\end{array}$ & $\begin{array}{l}M L L L \\
G E H^{2}\end{array}$ \\
\hline $\begin{array}{l}5 \\
5\end{array}$ & $\begin{array}{r}:-17 \\
48-25\end{array}$ & 10 Set $1980^{\circ}$ & $1 t: 15$ & 54 & 1015 & .6713 & 941 & 1 & $\$ .96$ & .21 & E0.88 & $\begin{array}{l}2.26 \\
. t 16\end{array}$ & $\begin{array}{r}.49 \\
.138\end{array}$ & $\begin{array}{r}.68 \\
.027\end{array}$ & $\begin{array}{r}.07 \\
.022\end{array}$ & .01 & $\begin{array}{r}0.00 \\
0.000\end{array}$ & .04 & $\begin{array}{r}100.00 \\
.023\end{array}$ & $\begin{array}{l}\text { MCLL } \\
\hat{\hat{\theta}},\}^{2}{ }^{2}\end{array}$ \\
\hline 6 & $\begin{array}{r}i-17 \\
1 E-2 j\end{array}$ & at Feb $\vdots 966$ & $09: 50$ & 65 & 2619 & .6572 & 947 & $i$ & 9.45 & .23 & 87,31 & $\begin{array}{l}2.29 \\
.624\end{array}$ & $\begin{array}{r}.49 \\
.138\end{array}$ & $\begin{array}{r}.0 E \\
.027\end{array}$ & $\begin{array}{r}.07 \\
.022\end{array}$ & $\begin{array}{l}.02 \\
.007\end{array}$ & $\begin{array}{r}.01 \\
.004\end{array}$ & .05 & $\begin{array}{r}100.06 \\
.843\end{array}$ & $\begin{array}{l}\text { Mo } \\
\text { op }\end{array}$ \\
\hline $\begin{array}{l}7 \\
7\end{array}$ & $\begin{array}{r}1-17 \\
18-25\end{array}$ & 11 Fet $1980^{\circ}$ & $23: 33$ & b2 & $10 \%$ & .6669 & 549 & 1 & 5.36 & .24 & 87.84 & $\begin{array}{l}2,31 \\
.630\end{array}$ & $\begin{array}{r}.51 \\
.143\end{array}$ & .00 & $\begin{array}{r}.07 \\
.22\end{array}$ & $\begin{array}{r}.02 \\
.007\end{array}$ & .01 & $\begin{array}{l}.06 \\
.025\end{array}$ & $\begin{array}{r}100.00 \\
.85 E\end{array}$ & \\
\hline $\begin{array}{l}\bar{\varepsilon} \\
\hat{\varepsilon}\end{array}$ & $\begin{array}{r}1-17 \\
18-25\end{array}$ & $: 2 \mathrm{FeE} 198 \mathrm{~s}$ & $16: 55$ & $n$ & 1040 & . 4575 & 947 & ! & 9.49 & $\therefore 3$ & E7.2. & $\begin{array}{l}2.31 \\
.630\end{array}$ & .49 & $\begin{array}{r}.09 \\
.417\end{array}$ & $\begin{array}{r}.07 \\
.62\end{array}$ & $\begin{array}{r}.0 ! \\
.014\end{array}$ & $\begin{array}{l}6.00 \\
6,000\end{array}$ & .02 & $\begin{array}{r}\text { thiso } \\
. \mathrm{E}\end{array}$ & $\begin{array}{l}50: 2 \\
5: 22\end{array}$ \\
\hline $\begin{array}{l}9 \\
9\end{array}$ & $\begin{array}{r}1-17 \\
13-25\end{array}$ & 17 fer 178 & $09:: 5$ & 69 & 985 & .6710 & 942 & : & 9.88 & $\therefore 4$ & $8 t .91$ & $\begin{array}{l}2.28 \\
.622\end{array}$ & $\begin{array}{r}.48 \\
.235\end{array}$ & n & $\begin{array}{r}.06 \\
.019\end{array}$ & $\begin{array}{r}.62 \\
.067\end{array}$ & .0 & $\begin{array}{l}.05 \\
.01\end{array}$ & $\begin{array}{r}10,00 \\
. E 31\end{array}$ & $\begin{array}{l}M d L \\
g F v z\end{array}$ \\
\hline $\begin{array}{l}16 \\
10\end{array}$ & $\begin{array}{r}1-17 \\
19-2 \vdots\end{array}$ & :9 Fet 198? & $1: 10$ & $i 2$ & 990 & .6793 & $94:$ & $\mathrm{i}$ & $9.5 !$ & .25 & 56.74 & $\begin{array}{l}2.29 \\
.024\end{array}$ & $\begin{array}{r}.5 \\
.4\end{array}$ & .67 & $\begin{array}{r}.05 \\
.015\end{array}$ &. .2 & .4 & $\begin{array}{r}.04 \\
.61^{7}\end{array}$ & $\begin{array}{r}96,59 \\
.655\end{array}$ & D \\
\hline $\begin{array}{l}\vdots 1 \\
11\end{array}$ & $\begin{array}{r}1-17 \\
25-95\end{array}$ & 15 igr :78? & $20: 25$ & $\ddot{3}$ & 605 & 4529 & $4 \bar{\phi} \bar{a}$ & $!$ & 5.14 & . & $50 . c^{4}$ & $\begin{array}{l}25 \\
25 \vdots \\
6 \vdots\end{array}$ & $\begin{array}{r}.49 \\
.198\end{array}$ & $\begin{array}{l}.67 \\
.62\end{array}$ & 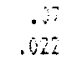 & $\begin{array}{l}3.60 \\
5.000\end{array}$ & $\begin{array}{l}.01 \\
.64\end{array}$ & .01 & $\begin{array}{r}100,30 \\
.85\end{array}$ & 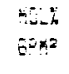 \\
\hline 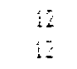 & $\begin{array}{l}:-17 \\
:-25\end{array}$ & 27 the 98 & it: & $9 i$ & $1 \%$ & $\therefore \leq n i q$ & 55. & : & $\therefore 9$. & $\pi$ & $E . E S$ & $\begin{array}{l}2.35 \\
.24\end{array}$ & $\begin{array}{l}5: 5 \\
.440\end{array}$ & .07 & .05 & 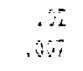 & .81 & .64 & $\begin{array}{r}65.50 \\
.350\end{array}$ & 74 \\
\hline
\end{tabular}

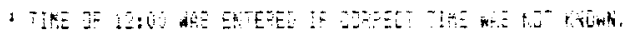

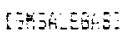

2 IF⿱

3. 
FHIE IS CHDLE 10.

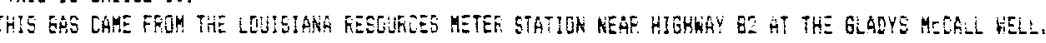

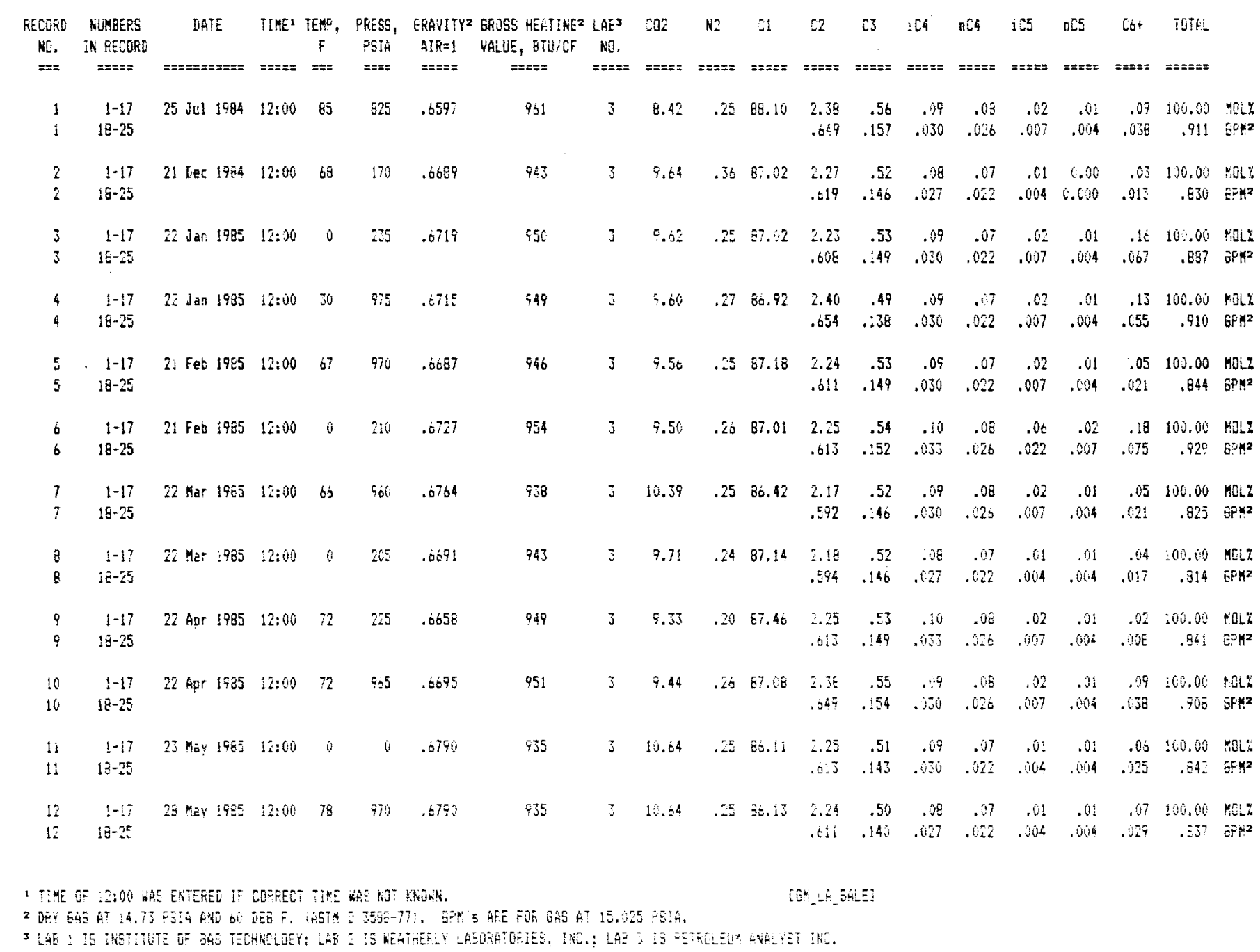


This is Cinte to

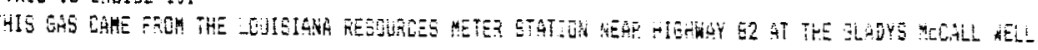

\begin{tabular}{|c|c|c|c|c|c|c|c|c|c|c|c|c|c|c|c|c|c|c|c|c|}
\hline $\begin{array}{l}\text { Nogh } \\
\text { Ne. }\end{array}$ & $\begin{array}{l}\text { NUKEERE } \\
\text { IN REUC:O }\end{array}$ & WATE & THE' & $\begin{array}{l}\text { TEXY } \\
\bar{y}\end{array}$ & $\begin{array}{l}\text { PYEES. } \\
\text { PS:A }\end{array}$ & $\begin{array}{l}\text { GEAYIYYZ } \\
\text { ABR=! }\end{array}$ & $\begin{array}{l}\text { GRCSS YERTJNG } \\
\text { VALiJE, STU/OF }\end{array}$ & $\begin{array}{l}\text { LeF } \\
\text { Mo. }\end{array}$ & 002 & $\$ 2$ & it & $a_{2}$ & 03 & $\mathrm{i} 34$ & 204 & $1: 5$ & $\pi C 5$ & $\tau \dot{c}^{+}$ & DTAL & \\
\hline$=x=$ & $:==2=$ & 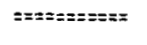 & $=:= \pm=$ & $z==$ & $= \pm=$ & z:=:= & $== \pm=$ & $== \pm=z$ & $=:= \pm=$ & $==z=z$ & $==:==$ & $==z=z$ & $=z= \pm=$ & $z=:=z$ & $z==:=$ & $=:== \pm$ & $=:== \pm$ & $== \pm=$ & $=: \pm=:=$ & \\
\hline $\begin{array}{l}13 \\
: 3\end{array}$ & $\begin{array}{r}1-17 \\
13-25\end{array}$ & 21 Jun :985 & $12: \%$ & $7 E$ & 210 & .6717 & 940 & 3 & 10.60 & .25 & $B 6, \bar{E} \dot{1}$ & $\begin{array}{l}2.25 \\
.612\end{array}$ & $\begin{array}{r}.50 \\
.140\end{array}$ & .08 & $\begin{array}{l}.016 \\
.017\end{array}$ & .01 & .01 & .013 & $\begin{array}{r}100.00 \\
.800\end{array}$ & moi \\
\hline $\begin{array}{l}14 \\
14\end{array}$ & $\begin{array}{r}1-17 \\
13-25\end{array}$ & $21 \mathrm{Jun} 198 \mathrm{~g}$ & $22: 03$ & 78 & 965 & .6753 & $\varphi+\hat{\varepsilon}$ & 3 & 9.74 & .82 & 86.23 & $\begin{array}{l}2.24 \\
.61 !\end{array}$ & $\begin{array}{r}.50 \\
.140\end{array}$ & $\begin{array}{l}.08 \\
.027\end{array}$ & .07 & .01 & .01 & .10 & $\begin{array}{r}100.00 \\
.350\end{array}$ & 促 \\
\hline $\begin{array}{l}15 \\
15\end{array}$ & $\begin{array}{r}1-17 \\
18-25\end{array}$ & $21 \mathrm{Jun} 1385$ & $12: 65$ & 78 & 965 & .6753 & 938 & 3 & 9.94 & .92 & 80.23 & $\begin{array}{l}2.24 \\
.611\end{array}$ & .50 & .08 & .077 & .01 & .01 & $\begin{array}{l}.10 \\
.342\end{array}$ & $\begin{array}{r}105.00 \\
.85\end{array}$ & $\begin{array}{l}\text { MOL } \\
\text { GP }\end{array}$ \\
\hline $\begin{array}{l}16 \\
16\end{array}$ & $\begin{array}{l}1-17 \\
18-25\end{array}$ & 19341985 & $12: 00$ & 78 & 965 & .6770 & $94:$ & 3 & 10.57 & .24 & 96.40 & $\begin{array}{l}2.29 \\
.622\end{array}$ & $\begin{array}{r}.51 \\
.145\end{array}$ & .08 & .07 & .02 & .01 & .12 & $\begin{array}{r}190,00 \\
.875\end{array}$ & $\begin{array}{l}\text { Mat: } \\
\text { gPat: }\end{array}$ \\
\hline $\begin{array}{l}17 \\
17\end{array}$ & $\begin{array}{r}1-17 \\
18-25\end{array}$ & 19341978 & $12: 00$ & $i \theta$ & 205 & .6758 & 933 & 3 & 6.34 & .25 & Eั่. $\{2$ & $\begin{array}{l}2.27 \\
.6 .7\end{array}$ & $\begin{array}{r}.50 \\
.40\end{array}$ & 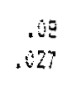 & .06 & .0 & $.0 !$ & .26 & $\begin{array}{r}: 00.30 \\
.838\end{array}$ & $\begin{array}{l}\text { ML: } \\
\text { GP? }\end{array}$ \\
\hline $\begin{array}{l}: 8 \\
18\end{array}$ & $\begin{array}{l}:-17 \\
1 \bar{G}-25\end{array}$ & 22 Aus :985 & $12: 60$ & 37 & 225 & .6736 & 947 & 3 & $9.8 \mathrm{i}$ & .29 & 36.66 & $\begin{array}{l}2.53 \\
.649\end{array}$ & $\begin{array}{l}t 5 \overline{5} \\
\therefore: 54\end{array}$ & .11 & .09 & .02 & .0104 & $\begin{array}{l}.11 \\
.042\end{array}$ & $\begin{array}{r}100.08 \\
.915\end{array}$ & MLL? \\
\hline $\begin{array}{l}19 \\
19\end{array}$ & $\begin{array}{r}1-17 \\
18-25\end{array}$ & 25 sec 1 15. & $12: \mathrm{w}^{2}$ & $a j$ & $99 \%$ & .5758 & 947 & 2 & 10.11 & .3 & 36.35 & $\begin{array}{l}2.32 \\
.63\end{array}$ & $\begin{array}{r}.52 \\
.146\end{array}$ & .09 & $.0 E$ & .02 & .01 & $\begin{array}{r}.20 \\
.0 \times 4\end{array}$ & $\begin{array}{r}100.03 \\
.929\end{array}$ & $\begin{array}{l}\text { KOLL" } \\
\text { GP: }\end{array}$ \\
\hline $\begin{array}{l}20 \\
20\end{array}$ & $\begin{array}{l}1-17 \\
15-25\end{array}$ & $2630: 58 z$ & $12: 40$ & 85 & 785 & .67 & 94 & 6 & 15.0 & .27 & 86.55 & $\begin{array}{l}2.07 \\
.63\end{array}$ & $\begin{array}{r}.5 i \\
.116\end{array}$ & $\begin{array}{l}. .68 \\
.97\end{array}$ & .07 & $.0 ?$ & .06 & $\begin{array}{l}.14 \\
.059\end{array}$ & $\begin{array}{r}100.60 \\
.898\end{array}$ & 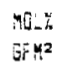 \\
\hline 24 & $\begin{array}{r}-17 \\
19-17\end{array}$ & 21 kor $195 \mathrm{~s}$ & $12: 40$ & 0 & 965 & .0402 & 971. & 2 & 7.35 & .25 & 99.22 & $\begin{array}{l}2.4 ! \\
.5 \pm ?\end{array}$ & $\begin{array}{r}.53 \\
.249\end{array}$ & .09 & .07 & .32 & .01 & $\begin{array}{l}.06 \\
.025\end{array}$ & $\begin{array}{r}.60 .60 \\
.895\end{array}$ & $\begin{array}{l}\text { MLL: } \\
\text { Sphn }\end{array}$ \\
\hline $\begin{array}{l}22 \\
22\end{array}$ & $\begin{array}{l}:-17 \\
15-z\end{array}$ & 21 ke: 1985 & $12: 9$ & 5 & 200 & .5720 & 943 & 5 & .95 & .25 & 86.8 & $\begin{array}{l}2.26 \\
.626\end{array}$ & $\begin{array}{r}.51 \\
.245\end{array}$ & .027 & .077 & .04 & .614 & .07 & $\begin{array}{r}100,30 \\
.845\end{array}$ & $\begin{array}{l}\text { MLL: } \\
\text { GPY" }\end{array}$ \\
\hline $\begin{array}{l}23 \\
23\end{array}$ & $\begin{array}{r}i-17 \\
18-25\end{array}$ & 23 Jes 1985 & 1200 & 0 & 975 & .65:4 & 957 & 2 & $8.0 i$ & .25 & 87.87 & $\begin{array}{l}2.27 \\
.622\end{array}$ & $\begin{array}{l}.52 \\
.14 t\end{array}$ & .090 & .67 & $\begin{array}{r}.02 \\
.007\end{array}$ & .04 & .08 & $\begin{array}{r}106.60 \\
.345\end{array}$ & $\begin{array}{l}\text { NiL\% } \\
\text { GE. }\end{array}$ \\
\hline $\begin{array}{l}24 \\
24\end{array}$ & $\begin{array}{r}:-17 \\
\vdots-25\end{array}$ & Jan 1936 & $12: 00$ & 63 & 206 & is & 94 & 3 & $9.5:$ & .27 & 87.18 & & $\begin{array}{l}5 \\
.5\end{array}$ & .28 & .019 & .214 & .94 & .198 & $\begin{array}{r}100.60 \\
.350\end{array}$ & $\mathrm{H}^{2}{ }^{2}$ \\
\hline
\end{tabular}

1. TIKE JF 12:00 WAS ENTERED IF MOREEST TIME WAS MGT NOAN.

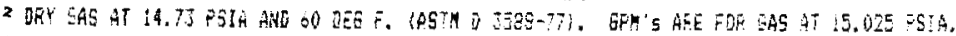

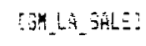

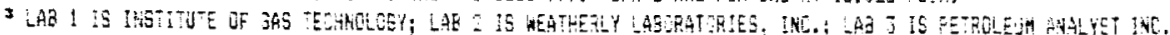


TH1S is CHOLE :U.

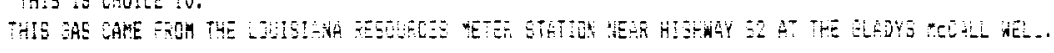

\begin{tabular}{|c|c|c|c|c|c|c|c|c|c|c|c|c|c|c|c|c|c|c|c|c|}
\hline $\begin{array}{l}\text { RESORD } \\
10 .\end{array}$ & $\begin{array}{l}\text { MUKEERS } \\
\text { N RECCRU }\end{array}$ & BHE & TWE & $\begin{array}{l}\text { TEt? } \\
F\end{array}$ & $\begin{array}{l}\text { PRESS, } \\
\text { PGIP }\end{array}$ & 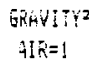 & 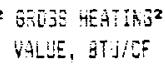 & $\begin{array}{l}\frac{L Y^{3}}{W} \\
W_{1}\end{array}$ & $02 ?$ & $x^{2}$ & ii & $z$ & 0 & 124 & r:C4 & 105 & $n: E$ & 26 & TUTAL & \\
\hline$==$ & $== \pm=$ & lo=s=z=z=z= & $==z=z$ & $===$ & $===$ & $= \pm= \pm=$ & $= \pm= \pm=$ & $= \pm \pm= \pm$ & $z=s=$ & $==z=8$ & $=z=z=$ & $=x= \pm$ & $:= \pm=z$ & $=:= \pm \pm$ & $=\geq \pm=z$ & $=2:=$ & $= \pm=:=$ & $= \pm=28$ & s=:s:= & \\
\hline $\begin{array}{l}25 \\
25\end{array}$ & $\begin{array}{r}1-17 \\
18-25\end{array}$ & $12=6.986$ & $10: 46$ & $i 2$ & $105 ?$ & .6277 & 949 & : & 9.41 & .23 & 87.23 & $\begin{array}{l}2.32 \\
.65\end{array}$ & $\begin{array}{r}.50 \\
.140\end{array}$ & $\begin{array}{l}.28 \\
.02 ?\end{array}$ & .07 & $\begin{array}{l}.01 \\
.011\end{array}$ & .01 & $\begin{array}{r}.07 \\
.029\end{array}$ & $\begin{array}{r}0000 \\
.360\end{array}$ & $\begin{array}{l}M O .: \\
\text { EPHE }\end{array}$ \\
\hline $\begin{array}{l}2 b \\
2 b\end{array}$ & $\begin{array}{c}1-17 \\
18-25\end{array}$ & 24 Mar 1795 & 2.00 & to & 95 & .6708 & 946 & $j$ & 4.72 & .26 & 86.98 & $\begin{array}{l}2.22 \\
.622\end{array}$ & $\begin{array}{r}.50 \\
.24 \%\end{array}$ & $\begin{array}{l}.09 \\
.027\end{array}$ & $\begin{array}{l}.07 \\
.022\end{array}$ & $\begin{array}{l}.01 \\
.004\end{array}$ & $\begin{array}{r}.0 \\
.014\end{array}$ & $\begin{array}{r}.09 \\
.038\end{array}$ & $\begin{array}{r}100.30 \\
.85 k\end{array}$ & $\begin{array}{l}\text { MEL: } \\
\text { SF }\end{array}$ \\
\hline $\begin{array}{l}27 \\
27\end{array}$ & $\begin{array}{r}1-17 \\
18-25\end{array}$ & 19 Jun 1986 & 1200 & $8 \mathrm{i}$ & 98.5 & .673 & 941 & 3 & $: 0.02$ & .7 & 36.74 & $\begin{array}{l}2.24 \\
.511\end{array}$ & $\begin{array}{r}.45 \\
.255\end{array}$ & $\begin{array}{r}.09 \\
.027\end{array}$ & $\begin{array}{r}.07 \\
.022\end{array}$ & .01 & .01 & $\begin{array}{r}.08 \\
.634\end{array}$ & $\begin{array}{r}10.00 \\
. E 20\end{array}$ & $\begin{array}{l}\text { MiLY } \\
G M^{2}\end{array}$ \\
\hline $\begin{array}{l}29 \\
28\end{array}$ & $\begin{array}{r}1-17 \\
18-25\end{array}$ & 21 Aug $198 \mathrm{~s}$ & 1200 & 84 & 3995 & .6705 & $\$ 45$ & 3 & 9.72 & .28 & 87.00 & $\begin{array}{l}2.28 \\
.016\end{array}$ & $\begin{array}{r}.44 \\
.138\end{array}$ & .03 & .06 & $\begin{array}{l}.0 ! \\
.004\end{array}$ & .01 & $\begin{array}{l}.09 \\
.030\end{array}$ & $\begin{array}{r}10.06 \\
.945\end{array}$ & $\begin{array}{l}M L^{2} \\
3 F Y P^{2}\end{array}$ \\
\hline $\begin{array}{l}29 \\
29\end{array}$ & $\begin{array}{r}:-17 \\
18-25\end{array}$ & 21 Nor $1980^{\circ}$ & $12: 00$ & 70 & 900 & .0680 & 949 & 3 & 9.45 & .25 & $37 . \dot{\mathrm{i}} \mathrm{I}$ & $\begin{array}{l}2.25 \\
.615\end{array}$ & .138 & $\begin{array}{r}.07 \\
.023\end{array}$ & .06 & .004 & .01 & $\begin{array}{l}.11 \\
.040\end{array}$ & $\begin{array}{r}100.60 \\
.850\end{array}$ & $\begin{array}{l}\mathrm{MELY} \\
\mathrm{BP} \mathrm{H}^{2}\end{array}$ \\
\hline $\begin{array}{l}30 \\
30\end{array}$ & $\begin{array}{r}1-17 \\
10-25\end{array}$ & 17 Se: 1986 & $12: 0$ & $5 \%$ & 603 & .5637 & 945 & 3 & 9.45 & .29 & 87.22 & $\begin{array}{l}2.27 \\
.617\end{array}$ & $\begin{array}{r}.53 \\
.147\end{array}$ & .07 & $\begin{array}{l}.06 \\
.019\end{array}$ & .01 & $\begin{array}{r}.01 \\
.304\end{array}$ & $\begin{array}{r}.12 \\
. .15 i 1\end{array}$ & $\begin{array}{r}10 \% .00 \\
.360\end{array}$ & $\begin{array}{l}\mathrm{MO} \mathrm{L}^{4} \\
\mathrm{grph}\end{array}$ \\
\hline $\begin{array}{l}31 \\
31\end{array}$ & $\begin{array}{r}4-17 \\
18-25\end{array}$ & 16 :an $\$ 787$ & 1200 & 51 & 1025 & .6688 & 947 & 3 & 9.56 & .23 & 87.15 & $\begin{array}{l}2.27 \\
.0 .7\end{array}$ & $\begin{array}{r}.51 \\
.143\end{array}$ & .07 & .010 & .01 & .004 & $\begin{array}{l}.09 \\
.638\end{array}$ & $\begin{array}{r}1 \% 0.00 \\
.600\end{array}$ & 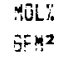 \\
\hline $\begin{array}{l}3 \hat{2} \\
32\end{array}$ & $\begin{array}{r}1-17 \\
18-25\end{array}$ & 23 Feb 1987 & $12: 10$ & 60 & 650 & $.5 \pi / 2$ & $74 !$ & $i$ & 10.2 & .24 & 85. 13 & $\begin{array}{l}2.23 \\
.619\end{array}$ & $\begin{array}{r}.50 \\
.140\end{array}$ & .37 & .06 & .01 & .01 & $\begin{array}{r}.09 \\
.054\end{array}$ & $\begin{array}{r}10.00 \\
.602\end{array}$ & 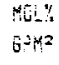 \\
\hline $\begin{array}{l}33 \\
33\end{array}$ & $\begin{array}{r}1-17 \\
18-25\end{array}$ & 21 Aor 1987 & $12: 00$ & 90 & 730 & .6697 & 947 & 3 & 9.92 & $\therefore 4$ & 37. 14 & $\begin{array}{l}2.25 \\
.615\end{array}$ & .45 & .07 & .08 & $\begin{array}{r}.64 \\
.024\end{array}$ & $\begin{array}{r}.61 \\
.094\end{array}$ & $\begin{aligned} .11 \\
.16\end{aligned}$ & $\begin{array}{r}100.08 \\
.347\end{array}$ & 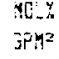 \\
\hline
\end{tabular}

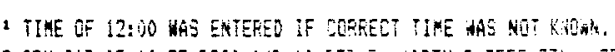

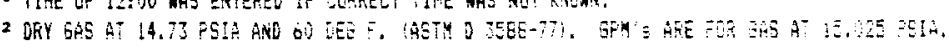

LS: L

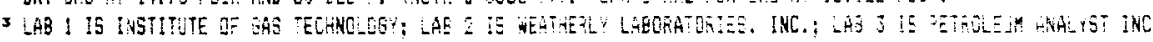


APPENDIX C

Compilation of "Total Gas" Analyses 


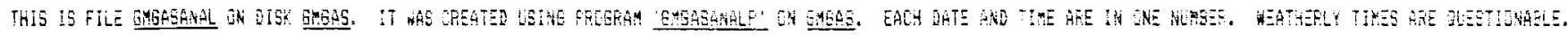

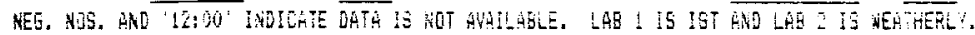

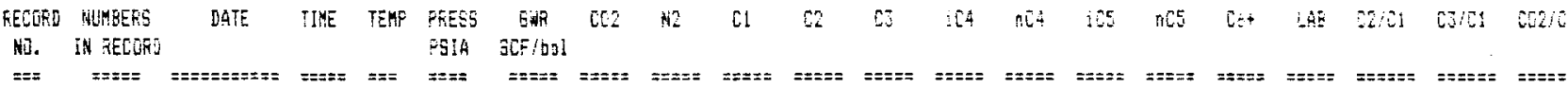

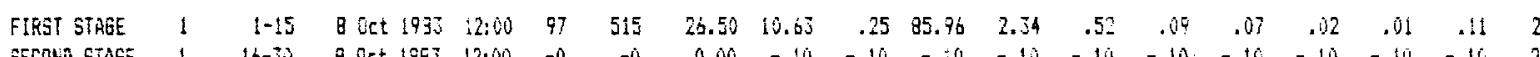

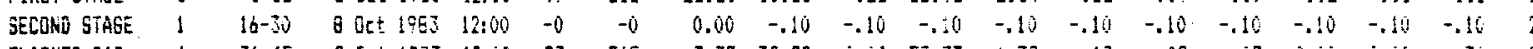

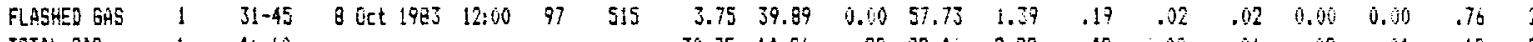

$\begin{array}{lllllllllllllll}\text { TOTAL GAS } & 1 & 46-60 & 30.25 & 14.26 & .22 & 32.45 & 2.22 & .48 & .08 & .06 & .02 & .01 & .19 & 2\end{array}$

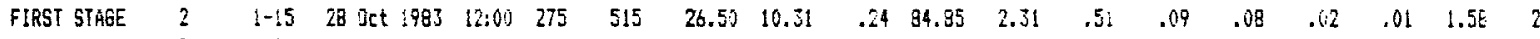

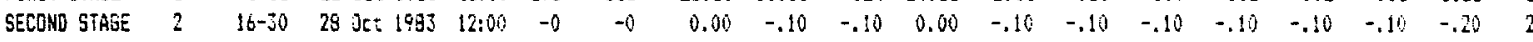

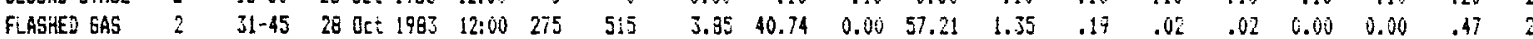

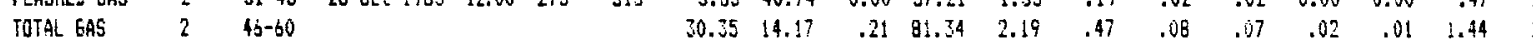

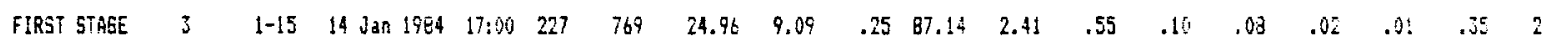

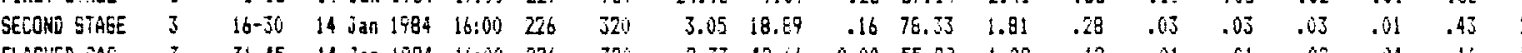

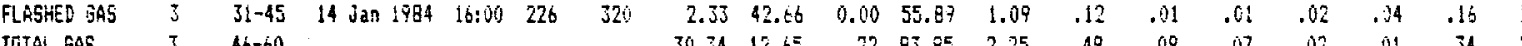

$\begin{array}{lllllllllllllll}\text { TOTAL GAS } 3 & 40-60 & 30.34 & 17.65 & .22 & 83.85 & 2.25 & .49 & .09 & .07 & .02 & .01 & .34 & 2\end{array}$

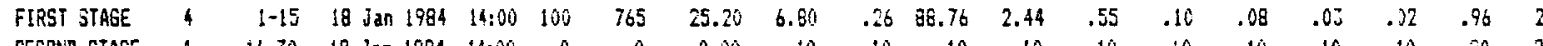

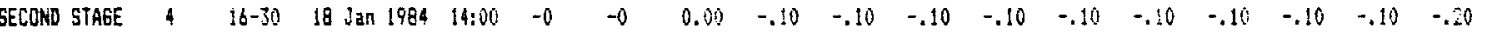

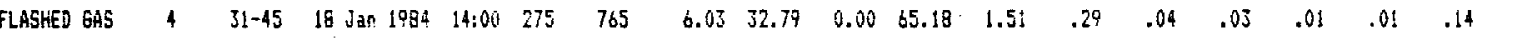

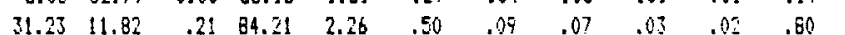

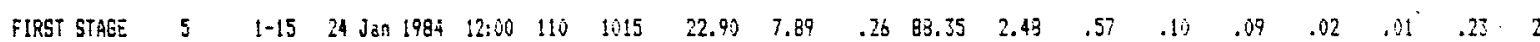

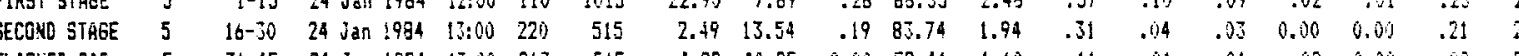

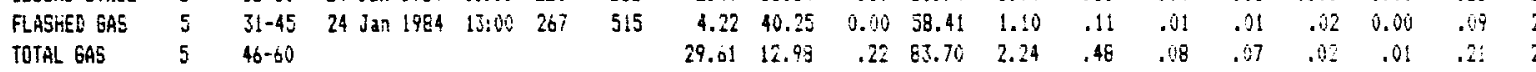

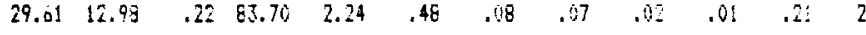

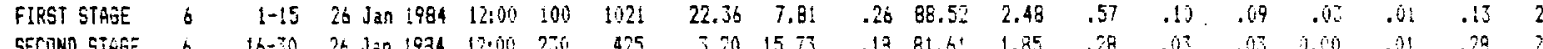

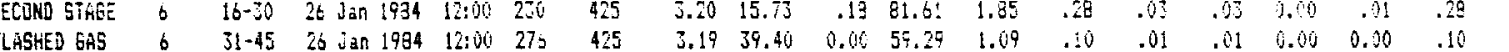

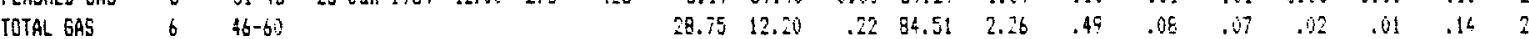

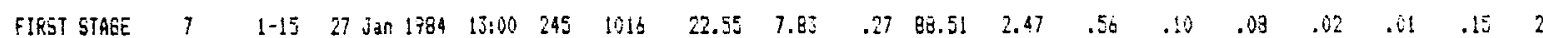

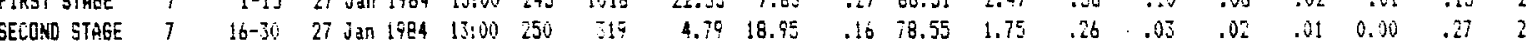

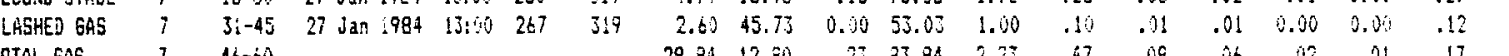

$46-50$

$29.94 \quad 12.70 \quad .25 \quad 33.84 \quad 2.23$

$.0269 \quad .0055 \quad .1729$

$.0269 \quad .0059 \quad .1742$

$.0269 \quad .0059 \quad .1509$

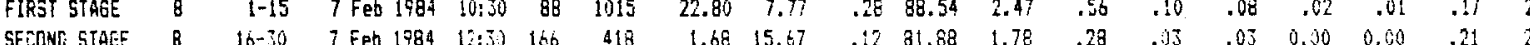

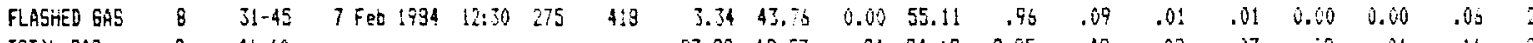

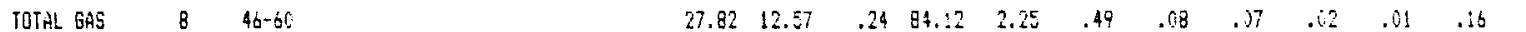

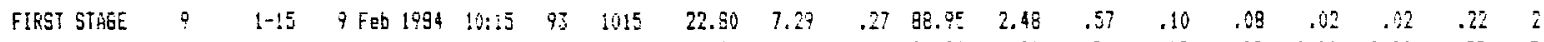

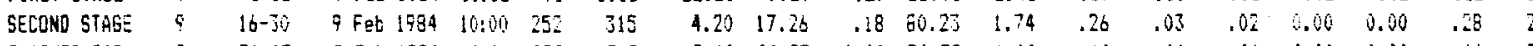

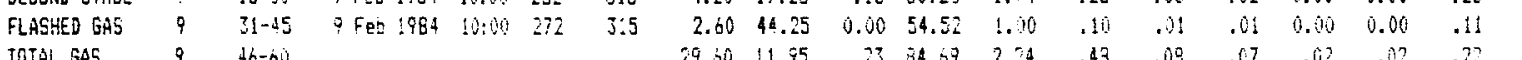

$6-60$

$29.30 \quad 11.95 \quad .23 \quad 34.69 \quad 2.24$

$.0268 \quad .0059 \quad .1403$

$.0267 \quad .0658 \quad .155$

$.0267 \quad .0657 \quad .1443$

$.0266 \quad .0055 \quad .1539$

$.067 \quad .0058 \quad .1494$

$.02 t 5 \quad .0057 \quad .1411$ 


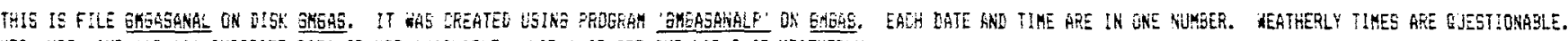

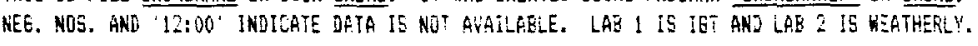

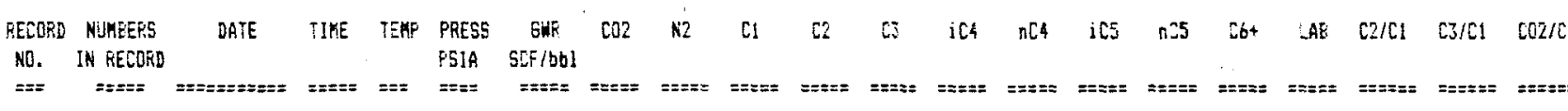

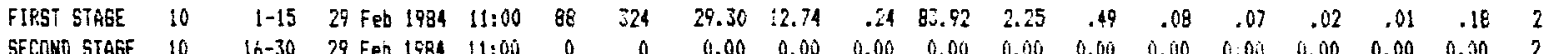

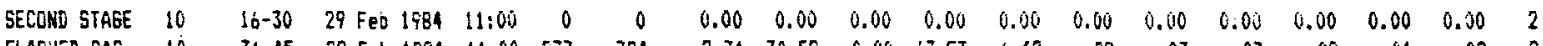

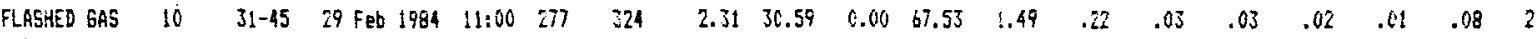

$\begin{array}{llllllllllllllll}\text { TOTAL GAS } 10 & 46-60 & 31.61 & 14.04 & .22 & 82.72 & 2.19 & .47 & .08 & .07 & .02 & .01 & .17 & 2 & & \end{array}$

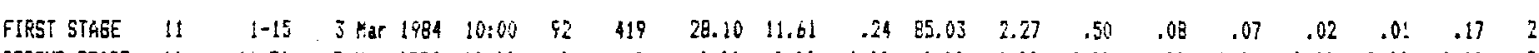

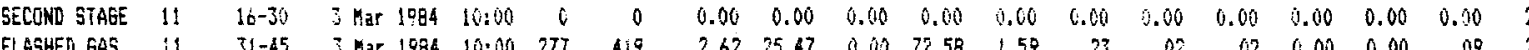

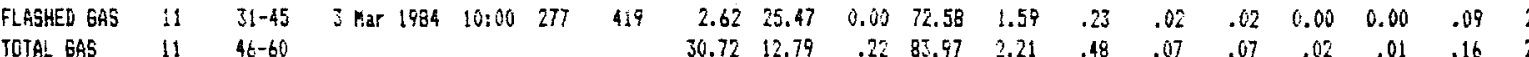

$\begin{array}{lllllllllllllllllll}\text { TOTAL EAS } & 11 & 4 t-60 & & & & & 30.72 & 12.79 & .22 & 85.47 & 2.21 & .48 & .07 & .07 & .02 & .01 & .16 \\ \text { FIRST STAEE } & 12 & 1-15 & 18 \text { JuI } 1984 & 14: 00 & 97 & 1015 & 22.30 & 7.86 & .25 & 88.59 & 2.45 & .56 & .10 & .08 & .02 & .01 & .13\end{array}$

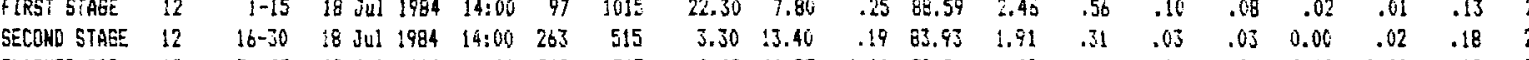

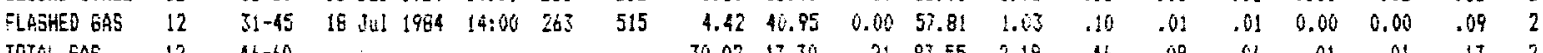

$\begin{array}{lllllllllllllllll}\text { TOTAL GAS } & 12 & 46-60 & 30.02 & 13.30 & .21 & 83.55 & 2.19 & .46 & .08 & .06 & .01 & .01 & .13 & 2\end{array}$

$\begin{array}{lrrrrrrrrrrrrrrrrrrrr}\text { FIFST STAGE } & 13 & 1-15 & 20 & 341 & 1984 & 12: 00 & 95 & 1015 & 23.10 & 7.83 & .26 & 38.57 & 2.46 & .56 & .10 & .08 & .02 & .01 & .11 & 2 \\ \text { SELOND STAGE } & 13 & 16-30 & 20 & 301 & 1984 & 12: 00 & 225 & 415 & 3.60 & 15.98 & .17 & 81.54 & 1.83 & .28 & .03 & .03 & 0.00 & 0.00 & .14 & 2\end{array}$

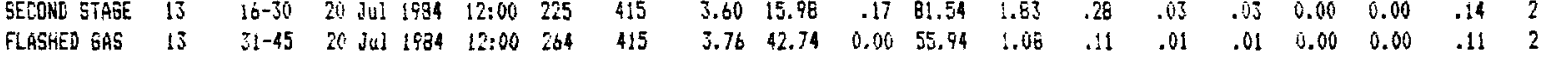

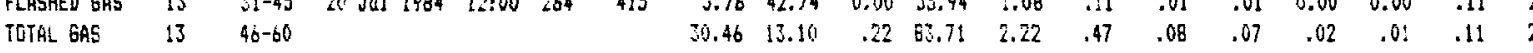

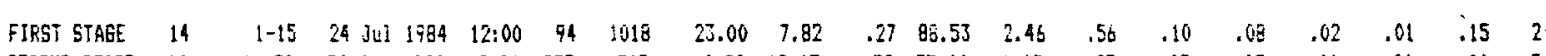

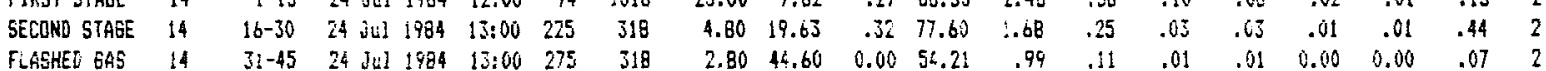

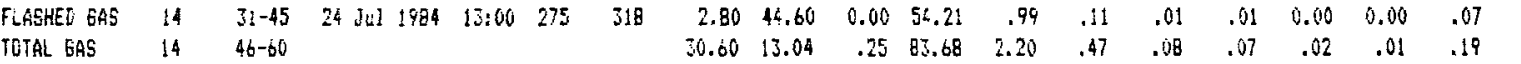

$\begin{array}{lllllllllllllllllllll}\text { FIFGT STAGE } & 5 & 1-15 & 26 & \text { JuI } & 1964 & 12: 00 & 82 & 1020 & 23.40 & 7.83 & .26 & 86.50 & 2.45 & .56 & .10 & .08 & .02 & .01 & .13 & 2\end{array}$

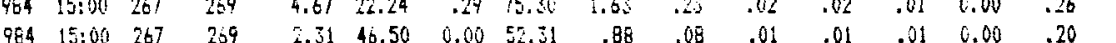

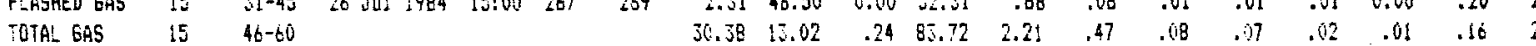

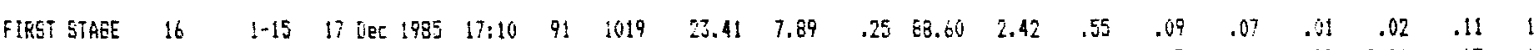

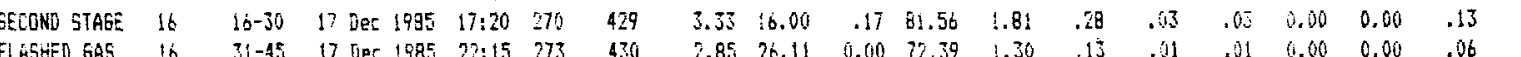

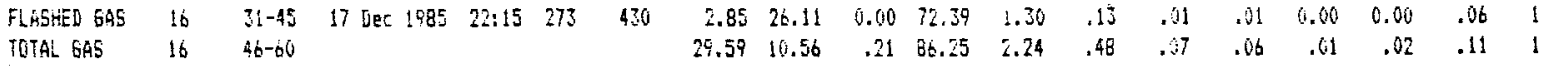

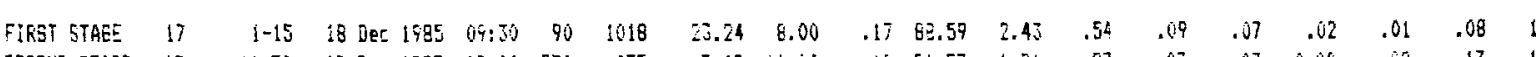

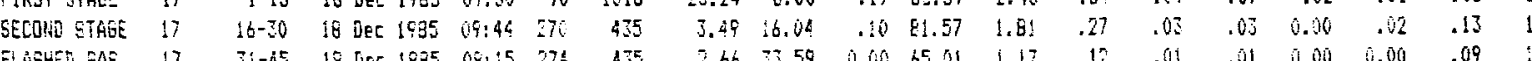

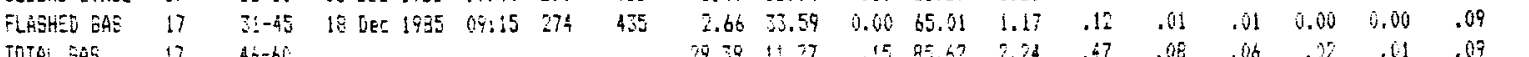

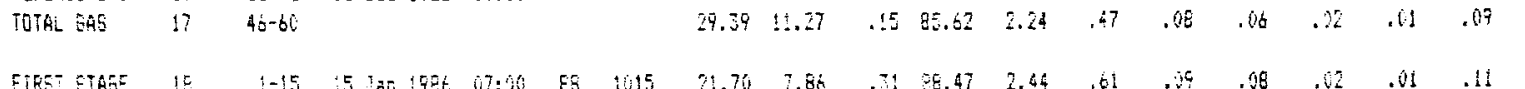

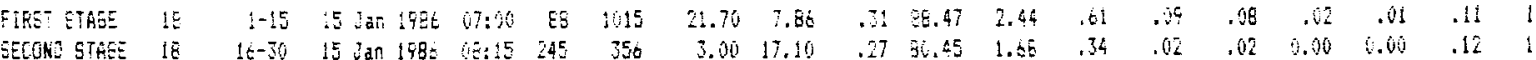

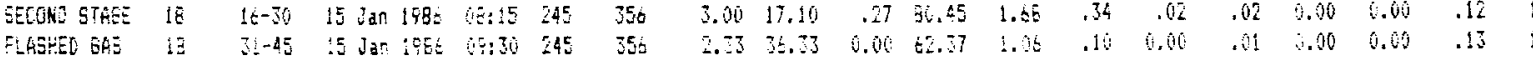

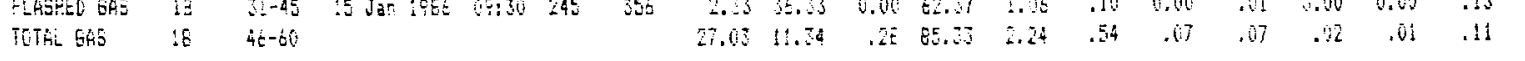




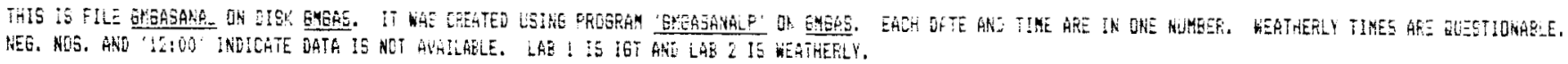

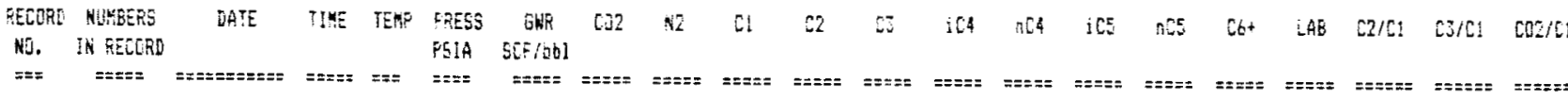

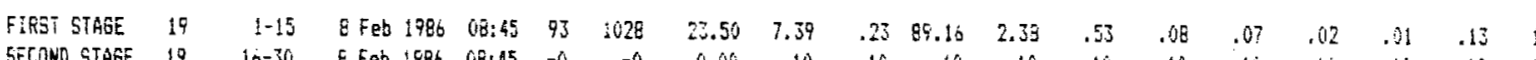

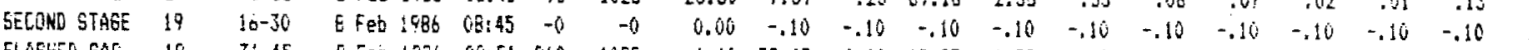

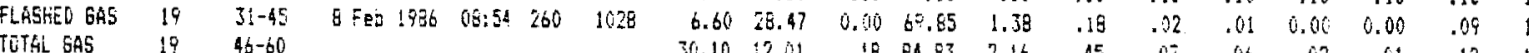

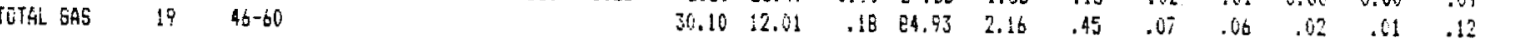

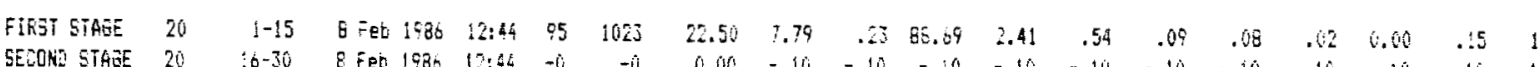

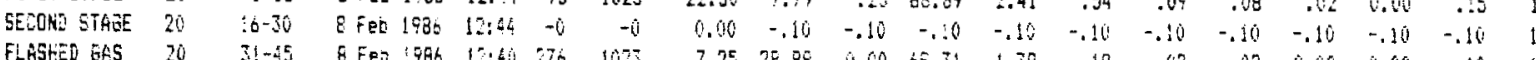

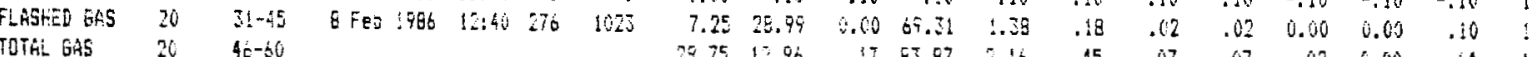

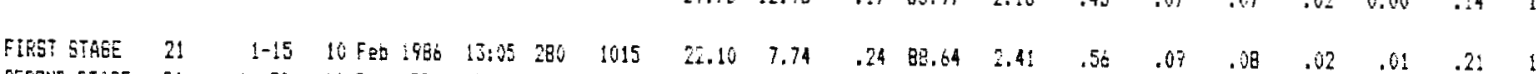

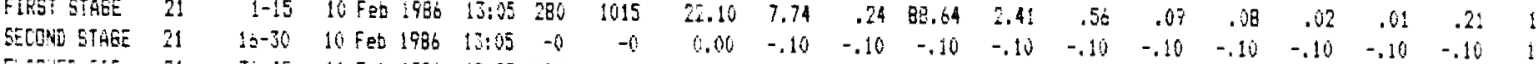

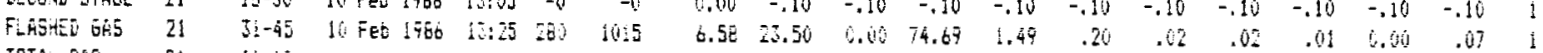

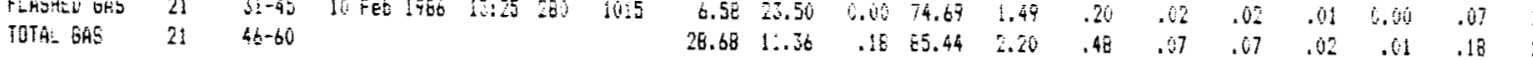

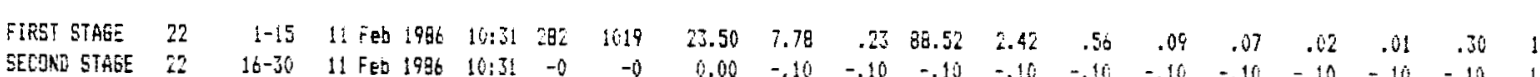

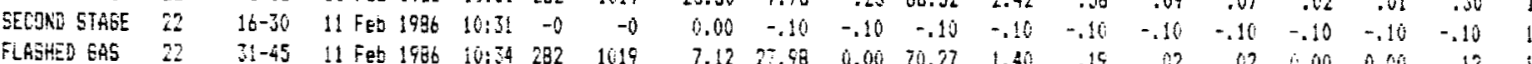

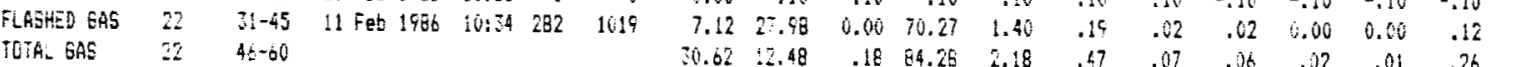

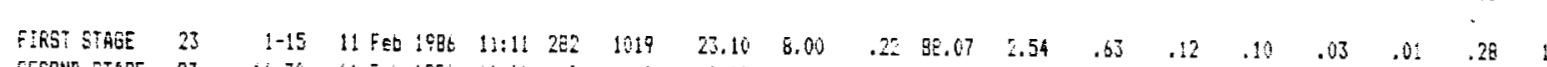

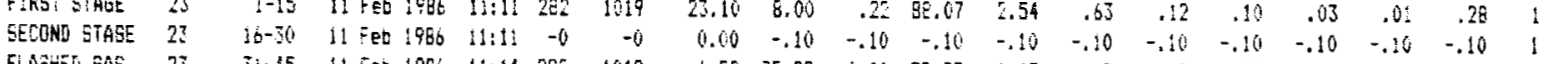

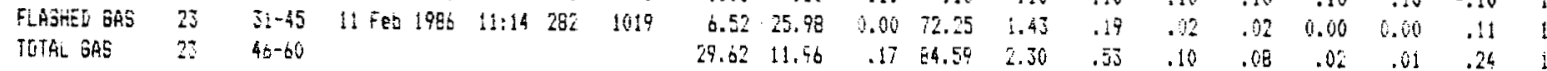

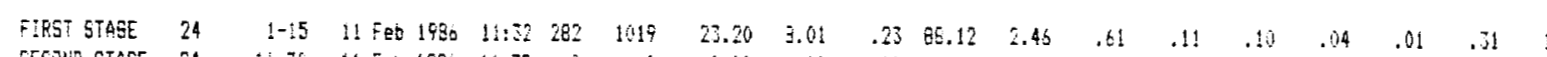

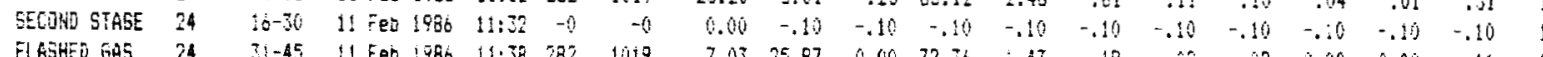

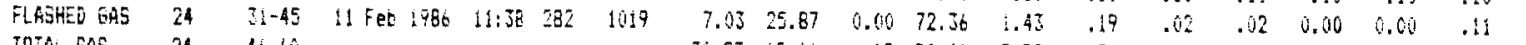

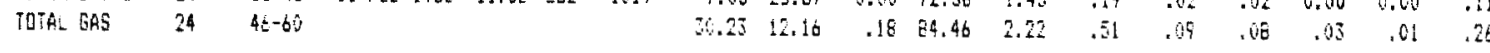

$.0254 \quad .0053 \quad .1414$

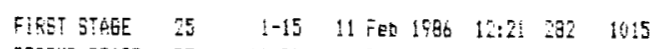

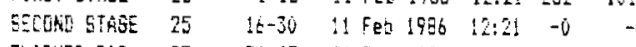

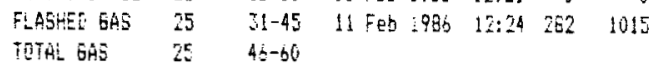

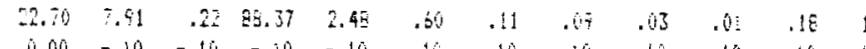

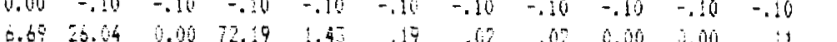

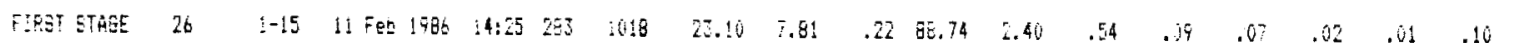

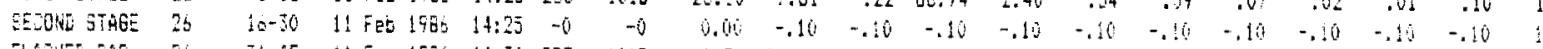

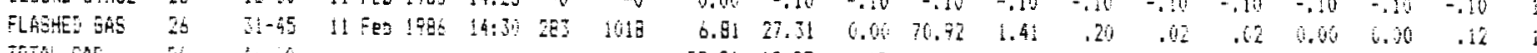

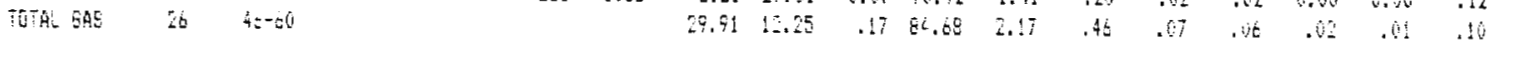

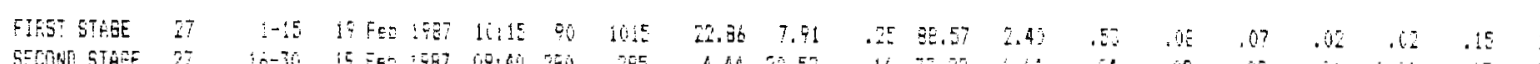

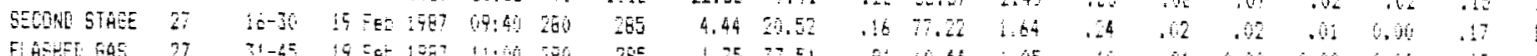

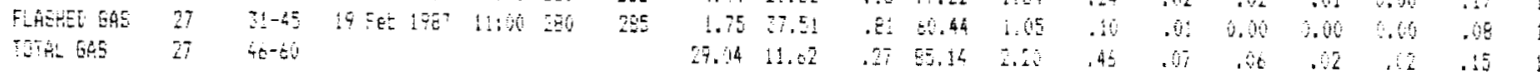




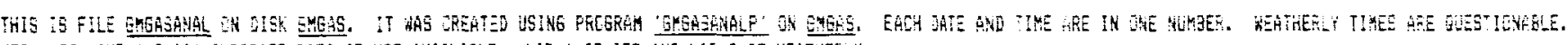

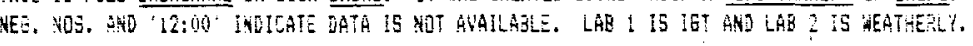

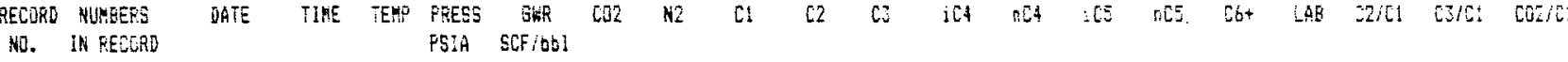

$$
\begin{aligned}
& \text { No. IN FEECRD }
\end{aligned}
$$

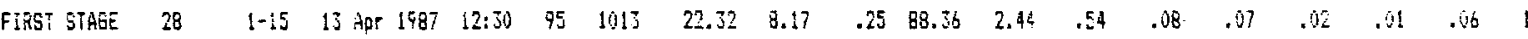

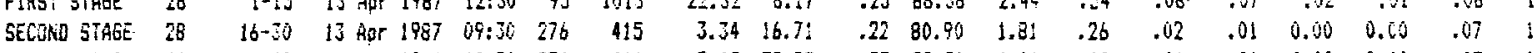

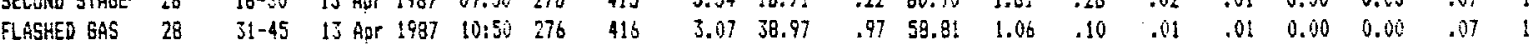

$\begin{array}{lllllllllllllllll} & & & \end{array}$

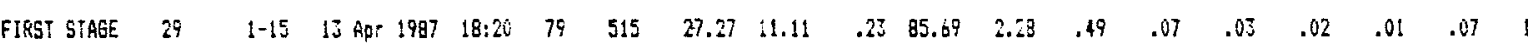

$\begin{array}{lllllllllllllllllll}\text { SECGND STAGE } & 29 & 16-30 & 13 & \text { Apr } 1987 & 17.40 & 250 & 410 & 1.20 & 13.89 & .19 & 83.35 & 2.06 & .36 & .04 & .84 & 0.00 & 0.00 & .07\end{array}$

$\begin{array}{llllllllllllllllllll}\text { FLASHEJ GAS } & 29 & 31-45 & 13 \text { Apr } 1987 & 19.00 & 253 & 418 & 2.91 & 33.59 & .96 & 53.95 & 1.26 & .15 & .01 & .01 & 0.00 & 0.00 & .07\end{array}$

$\begin{array}{llllllllllllll}\text { TOTAL GAS } & 29 & 46-50 & 31.38 & 13.30 & .30 & 83.58 & 2.18 & .45 & .06 & .03 & .02 & .01 & .07\end{array}$

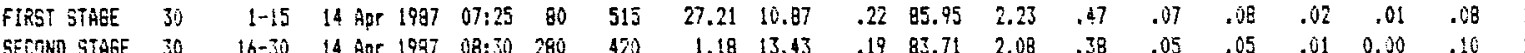

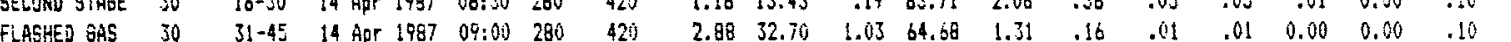

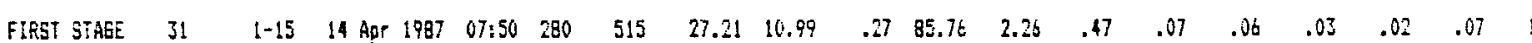

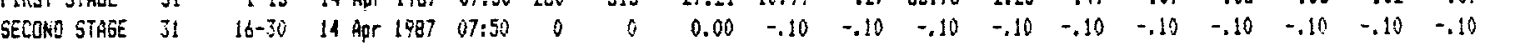

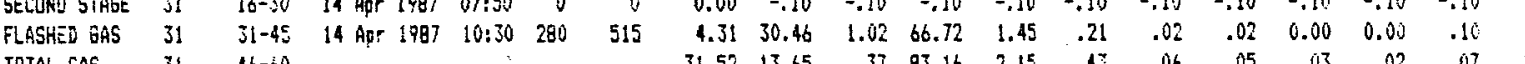

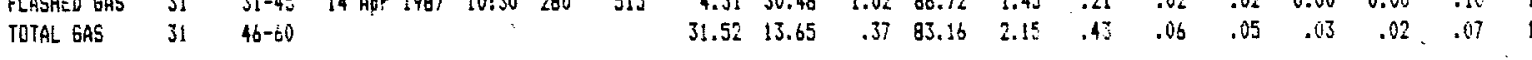

$.0 .63 \quad .0055 \quad .1477$

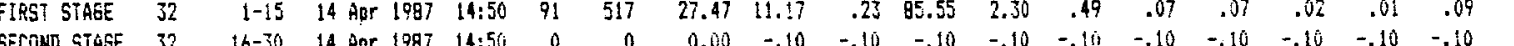

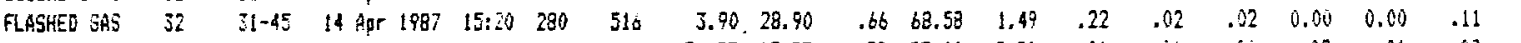

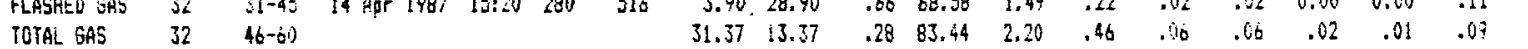

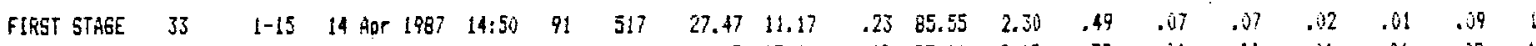

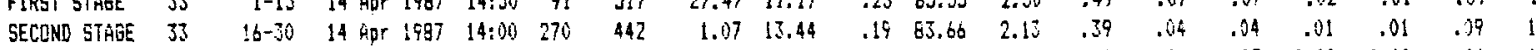

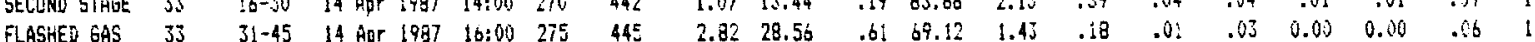

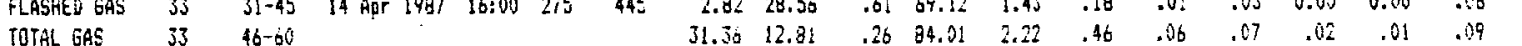

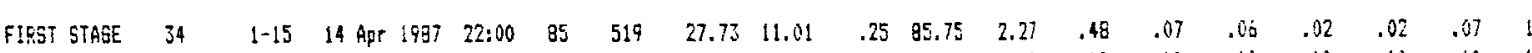

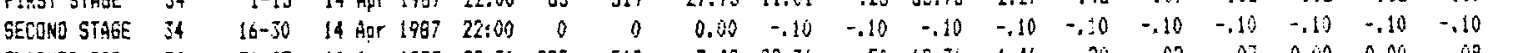

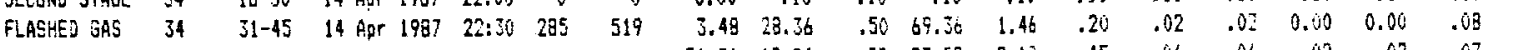

$\begin{array}{lllllllllllllll}\text { TOTAL GAS } & 34 & 46-60 & 31.21 & 12.94 & .28 & 83.92 & 2.18 & .45 & .06 & .06 & .02 & .02 & .07 & 1\end{array}$

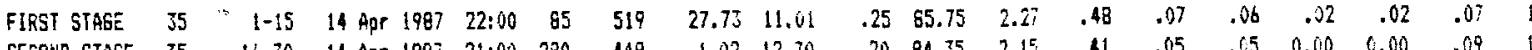

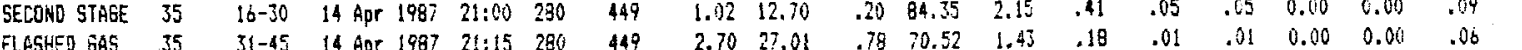

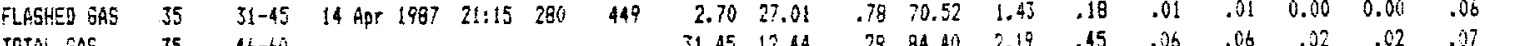

$\begin{array}{lrrrrrrrrrrrrrrrrrr}\text { FiRST STAGE } & 36 & 1-15 & 15 \text { Apr } 1998 & 06: 25 & 73 & 515 & 27.68 & 11.09 & .22 & 85.70 & 2.29 & .49 & .07 & .06 & 0.019 & 0.00 & .08 & 10 \\ \text { SECRND STAGE } & 36 & 16-30 & 15 \text { Apr } 1997 & 06: 25 & 0 & 0 & 0.00 & -.10 & -.19 & -.10 & -.10 & -.10 & -.10 & -.11 & -.10 & -.10 & -.10 & 10\end{array}$

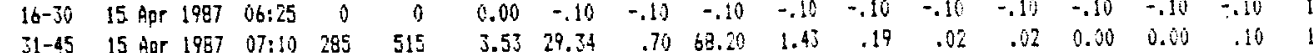

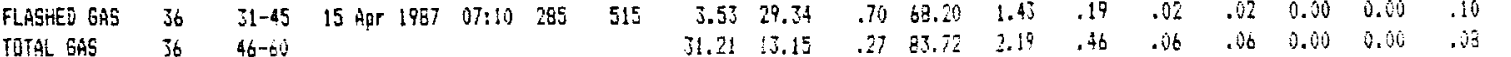

$.0258 \quad .0052 \quad .1642$

$.0254 \quad .0055 \quad .3503$

$.0254 .0055 \quad .1525$

$.0230 \quad .0053 \quad .1542$

$.0265 \quad .0954 \quad .1474$

.0228 .0054 .153 